\title{
EFEITOS DA VINHAÇA EM ALGUMAS PROPRIEDADES QUÍMICAS E FÍSICAS DE UM LATOSSOLO VERMELHO ESCURO TEXTURA MÉDIA
}

ITAMAR ANDRIOLI

Orientador: Prof. Dr. ANDRÉ MARTIN LOUIS NEPTUNE

Tese apresentada à Escola Superior de Agricultura "Luiz de Queiroz", da Universidade de São Paulo, para obtenção do Título de Doutor em Agronomia. Área de Concentração: Solos e Nutrição de Plantas.

P I R A C I C A B A

Estado de São Paulo - Brasil

Dezembro, 1986 
Aos meus pais

com a eterna gratidão

pelo apoio que recebi

D E D I C O

Aos meus ixmãos e cunhados

e à Maurizeni, Fabrícia,

Giseli e Itamarzinho

$O F E R E C O$ 
Ao Prof. Dr. André Martin Louis Neptune pela orien tação e amizade.

Ao Conselho Nacional de Desenvolvimento Científico e Tecnológico CNPq pela bolsa concedida.

As Usinas Santa Adélia e São Geralḋo pelo apoio e fornecimento de vinhaça.

Aos Professores Edson Luiz Meńdes Coutinho, Paulo César Corsini e Euridice Saçchi, pela colaboração prestada.

A funcionậria do Departamento de Solos e Adubos (UNESP-Jaboticabal), Maria Inês Bueno Tofani e aos demais funcionários desta unidade de ensino pela colaboração prestą da.

A Sra. Salete Aparecida Costa Biondi pelo serviço de datilografia.

A todos que direta ou indiretamente contribuiram pa ra a execução desse trabalho. 
$\operatorname{RESUMO} \ldots \ldots \ldots \ldots \ldots \ldots \ldots \ldots \ldots \ldots \ldots \ldots \ldots$

SUMMARY ............................. viii

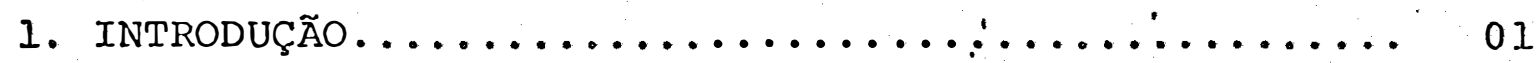

2. REVISÃo DE LITERATURA..................... 03

2.1. Efeitos da vinhaça nas propriedades químicas

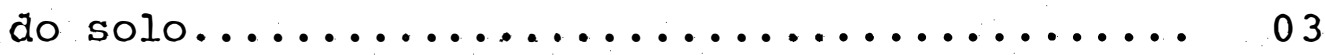

2.2. Efeitos da vinhaça nas propriedades físicas do solo............................ 14

3. MAterial e metodos...................... 20

3.1. Caracterização da ârea de estudo......... 20

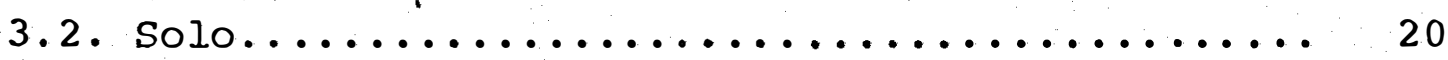

3.3. Delineamento experimental............. 21

3.4. Vinhaça: composição e processo de aplicação... 21

3.5. Cobertura plástica................. 24 .

3.6. Coleta dos dados.................... 24

3.6.1. Amostras com estrutura indeformada.... 24 
Página

3.6.2. Amostras com estrutura deformada...... 24

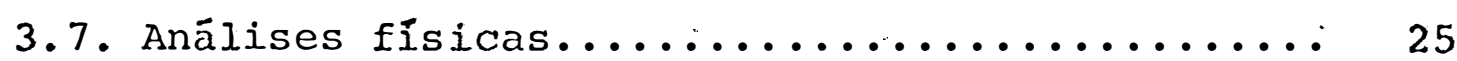

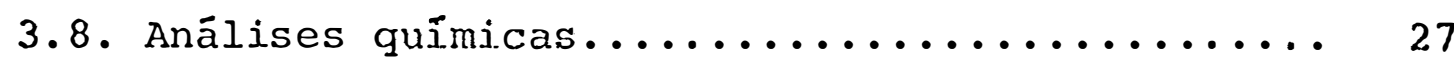

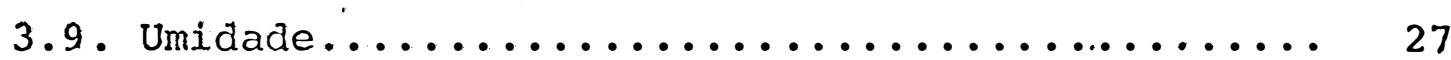

4. RESULTADOS E DISCUSSÃo...................... 28

4.1. Valor pH do solo, concentrações de H+Al e fós

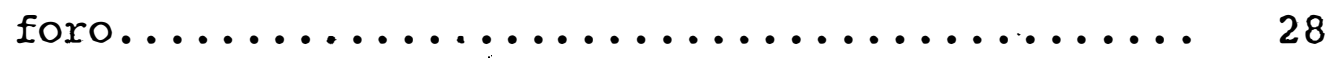

4.2. Teor de matéria orgânica do solo........... 38

4.3. Cálcio, magnésio e potássio do solo.......... 39

4.4. Capacidade de troca catiônica e saturação em

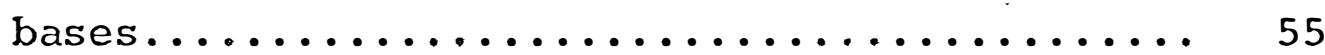

4.5. Caracterização do meio poroso.............. 60

4.6. Argila natural e grau de floculação......... 65

4.7. Condutividade elétrica................. 67

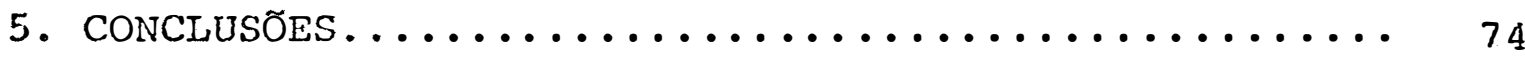

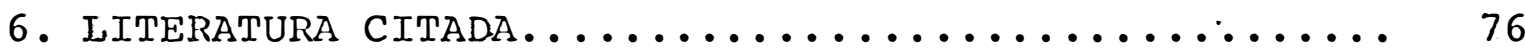


EFEITOS DA VINHAÇA EM ALGUMAS PROPRIEDADES QUTMICAS E FISICAS DE UM LATOSSOLO VERMELHO ESCURO TEXTURA MEDIA

\author{
Candidato: Itamar Andrioli \\ Orientador: Prof. Dr. André Martin Louis Neptune
}

RESUMO

Com o objetivo de se verificar os efeitos de doses crescentes de vinhaça, na presença e ausência das āguas de chuvas, nas propriedades químicas e físicas em diferentes pro fundidades, instalou-se um experimento em Latossolo Vermelho Escuro - textura média localizado no município de Jabotica bal. O delineamento experimental utilizado foi em blocos ca sualizados ( 3 repetições) combinando-se cinco doses de vinha ça $\left(0-150-300-600-1200 \mathrm{~m}^{3} / \mathrm{ha}\right)$ com duas condições a saber: com cobertura plástica e sem cobertura plástica e três épocas de amostragem.

As doses de vinhaça foram parceladas em três vezes, em partes iguais e.aplicadas. periodicamente perfazendo três aplicações.

Amostragens de solo em diferentes profundidades fo ram efetuadas em intervalos de aproximadamente 90 dias após cada aplicação da vinhaça" com o objetj.vo de se avaliar as pos 
sĩveis alterações em algumas propriedades físicas e químicas do solo.

Durante o período experimental determinou-se da umidade do solo em função do tempo e da profundidade até 60 $\mathrm{cm}$.

Através dos resultados obtidos, pode-se concluir que :

a) a densidade global, porosidade total, macroporo sidade e microporosidade, grau de floculação, os teores de matéria orgânica e fósforo não foram alterados significativa mente pelos tratamentos utilizados.

b) o teor de sais foi aumentado em função das do ses crescentes da vinhaça até $30 \mathrm{~cm}$ de profundiảade.

c) os tratamentos com vinhaça que receberam as ãguas de chuvas apresentaram uma diminuição nos teores de sais principalmente na camada de 0-10 $\mathrm{cm}$.

d) as doses de vinhaça aumentaram significativamen te as concentrações de $\mathrm{Ca}, \mathrm{Mg}$ e $\mathrm{K}$ e até as profundidades de 10, 30 e $60 \mathrm{~cm}$ respectivamente e reduziram os teores de $\mathrm{H}+\mathrm{Al}$ nos primeiros $10 \mathrm{~cm}$.

e) as águas das chuvas não afetaram significativa mente os teores de $\mathrm{Mg}$ e $\mathrm{K}$ do solo a partir de 10 e $30 \mathrm{~cm}$ res pectivamente. 
d) o comportamento dos valores da soma de bases, saturação de bases, K. $\mathrm{S}^{-1} .100, \mathrm{~K} . \mathrm{T}^{-1} .100$ para os diferentes tratamentos é função principalmente das alterações ocorridas nos teores de $k$. 
EFFECTS OF VINASSE ON SOME CHEMICAL AND PHYSICAL PROPERTIES OF A TYPIC HAPLORTOX

Author: Itamar Andrioli

Adviser: Prof. Dr. André Martin Louis Neptune

SUMMARY

With the intend to study the effect of different rates of vinasse with and without rainfed control on physical and chemical properties at different depths a field . trial was carried out in a typic Haplortox, medium texture, near Campus Jaboticabal. The experiment was lait out in randomized block design with 3 replications. The treatments consisted of 5 rates of vinasse: $0,150,300,600$ and $1200 \mathrm{~m}^{3}$ per ha, com bined with two conditions: one with rainfed control and the other without rainfed control. The vinasse rate was divided equally and applied three times. The soil samples at diffe rent depth were realized in 90 days approximately after each application of vinasse in order to evaluate the possible chan ges in the chemical and physical soil properties. Also during the experiment, the soil moisture content was determined, up to $60 \mathrm{~cm}$ deep.

From the experimental results it was concluded that: 
a) the bulk density, the total porosity, the macro porosity, the microporosity, floculation grade, the organic matter content and the phosphorous concentrations were not changed significantly by the treatments used.

b) as the vinasse rate was increased the rate of salt in solution was augmented up to $30 \mathrm{~cm}$ deep:

c) the treatments with vinasse that received rain fed had a lower rate of salt in solution, mainly in the layer of $0-10 \mathrm{~cm}$.

d) the vinasse rate increased significantly the Ca, Mg and $\mathrm{K}$ concentrations up to 10,30 and $60 . \mathrm{cm}$ deep respecti vely. The rate decreased the $\mathrm{H}+\mathrm{Al}$ concentrations in the first $10 \mathrm{~cm}$.

e) the rainfed did not affect significantly the Mg and $\mathrm{K}$ concentrations below 10 and $30 \mathrm{~cm}$ deep, respectively.

f) saturation base, base total K. $\mathrm{s}^{-1} \cdot 100$ and $\mathrm{K} . \mathrm{T}^{-1} \cdot 100$, for the different treatments depend upon mainly of the $\mathrm{K}$ concentrations changes. 
1. INTRODUÇÃO

O presente trabalho está integrado num programa de estudo que se propõe obter melhor conhecimento do comporta mento da vinhaça no sistema solo-água-planta.

Numa primeira etapa, em condições de laboratório, procurou-se conhecer aspectos relacionados com 0 movimento do íon potássio no solo e sua interaçãó com a dinâmica da ví nhaça e da água no solo, através dos processos de redistribui ção de vinhaça e evaporação da água do solo ANDRIOLI (1982). Neste sentido, verificou-se que a translocação do íon potássio no solo está mais estritamente relacionado ao processo da entrada da vinhaça no solo, o qual ocorre a al tos graus de umidade. Para valores de umidade abaixo de $\underline{0,30}$. $\mathrm{cm}^{3} \cdot \mathrm{cm}^{-3}$, o processo de translocação do íon potássio foi para lizado, que ocorreu a $12 \mathrm{~cm}$ de profundidade. Em consequêricia destes fatos houve um aumento no teor de potássio na camada superficial do solo, especialmente quando se aplicou doses 
mais elevadas de vinhaça.

o conhecimento destes fenomenos, em condições de campo, é de fundamental importância para o uso racional da ví nhaça nos solos, uma vez que naquelas condições poderão ocor rer um aumento de sais naquela camada, principalmente durante um período de estiagem, podendo afetar o desenvolvimento da cultura instalada nestes solos.

Por outro lado nas pesquisas conduzidas em condi ções de campo, tem procurado verificar de uma maneira geral, os efeitos desse efluente em algumas propriedades químicas do solo, dando-se pouca enfase às propriedadés físicas.

Dessa maneira, procurou-se nestá segunda etapa verificar os efeitos de doses crescentes de vinhaça, na pre sença e ausência das águas de chuvas, nas propriedades quími cas e físicas em diferentes profundidades em um Latossolo Ver melho Escuro - textura média. 
2. REVISÃO DE LITERATURA

2.1. Efeitos da vinhaça nas propriedades químicas do solo a) pH e acidez trocāvel

A viabilidade de utilização da vinhaça na agri cultura, foi demonstrada inicialmente por ALMEIDA et alii (1950). Os autores observaram que a aplicação de doses até $1000 \mathrm{~m}^{3} /$ ha promovia um acréscimo no valor $\mathrm{pH}$ do solo, contra riando as expectativas existentes na época. Esse resultado foi confirmado em estudo posterior, efetuaco por ALNEIDA (1952), o qual empregou $500 \mathrm{~m}^{3} /$ ha de vinhaça sulfúrica e pentaclorofe nolina.

Dentro desse contexto, ALMEIDA (1953) propõe a primeira explicação para o incremento no valor $\mathrm{pH}$ de solos que receberam vinhaça: o aúmento da população microbiana que atacando a matéria orgânica e decompondo-a parcialmente, se ria a causa da diminuição da acidez do solo. 
Esses resultados iniciais foram ainda confirma dos por outros experimentos realizados no Estado de São Paulo (VALSECHI e GOMES, 1954) e no Estado de Pernambuco (CALDAS, 1960 a).

Os trabalhos citados anteriormente foram de - grande importância, isto porque foram pioneiros no que se re fere à utilização da vinhaça na agricultura. Entretanto, devi do as doses elevadas utilizadas, tornando-as não econômicas, e ainda ao pequeno conhecimento de outros efeitos desse resí duo, fizeram com que o uso do vinhoto em solos agrícolas não se generalizasse.

Entretanto com o aumento na prọdução de açúcar e álcool e a intensificação da fiscalização, no sentido de evitar a poluição dos cursos d'água, resultaram na necessida de de novos estudos, com o objetivo de śe conhecer melhor os efeitos desse efluente no sistema solo-planta.

Neste sentido vários experimentos foram conduzi dos, confirmando de uma maneira geral os resultados obtidos na década de 50, onde a vinhaça promovia uma elevação no $\mathrm{pH}$ . do solo (NUNES et alii, 1981; SOBRAL et alii, 1981; CAMARGo et alii, 1983; COLETI et alii, 1983; ORLANDO FILHO et alii, 1983; RIBEIRO e SENGIK, 1983; MAZZA, 1985; CAMBUIM e CORDEI RO, 19.862 .

A variação do $\mathrm{pH}$ do solo, tem comportamento dife rente em solos tratados com vinhaça dependendo da textura dos 
mesmos. Assim, FERREIRA (1980) observou que a aplicação de do ses de vinhaça até $1600 \mathrm{~m}^{3} / \mathrm{ha}$ promoveu incrementos de 2,1 uni dades no valor $\mathrm{pH}$ de um solo de textura arenosa, sendo esse aumento bastante superior aos verificados nos solos de textu ra média e argilosa.

Embora os trabalhos citados anteriormente, mos trem uma tendência geral quanto a diminuição da acidez dos so los tratados com vinhaça, deve-se ressaltar que este efeito é dependente do tempo transcorrido após a aplicação do resíduo.

REZENDE (1979) verificou um incremento no valor pH após 15 dias da aplicação do vinhoto. Contudo essa tendên cia não foi confirmada, quando a amostragem dẹ solo foi efetua da aos 60 e 120 dias após a aplicação do resíduo. Esses resul tados foram corroborados por LIMA (1980), quando o Podzólico Vermelho Amarelo foi incubado com as dośes de 150 e $300 \mathrm{~m}^{3} / \mathrm{ha}$.

Entretanto deve-se mencionar, que a dose de vi nhaça exerce uma grande influência nesta variável.

Neste sentido, IIMA (1980) utilizando doses mais elevadas $\left(600 \mathrm{e} 1200 \mathrm{~m}^{3} / \mathrm{hal}\right.$, verificou que o efeito desse re . síduo no valor pH do solo era mantido até um período de 66 dias de incubação. 'SANTOS et alii (1981) observaram que para um período de incubação de 7 dias, doses equivalentes a 200 $\mathrm{m}^{3} / \mathrm{ha}$ eram suficientes para elevar o $\mathrm{pH}$ do solo, ao passo que para 30 dias de incubação, acréscimos nessa variável somente foram conseguidos com doses superiores a $800 \mathrm{~m}^{3} / \mathrm{ha}$.

Desta maneira fica evidenciado, que os efeitos 
da vinhą̧a no pH do solo são efêmeros, voltando aos valores originais após um determinado período de tempo (RODELLA et alii, 19832.

Resultados divergentes foram obtidos por COLETI et alii (1983). Os autores acompanharam ao longo do tempo, os efeitos da vinhaça nas propriedades químicas de cinco solos representativos do Estado de São Paulo, verificando que o $\mathrm{pH}$ atingiu valores mäximos ao redor de 100 dias, decrescendo a seguir, mas sendo sempre superior aos valores iniciais.

Segurdo REZENDE (1979) os incrementos no $\mathrm{pH}$ do solo ocorrem somente na profundidade de até $5 \mathrm{~cm}$. Contude,CAM BUIM e CORDEIRO (19.86) empregando doses mais elevadas, detec taram alterações nessa variável até a profundidade de $30 \mathrm{~cm}$.

Por outro lado, vários trabalhos tem demonstra do que a aplicação de vinhoto reduz as concentrações de alumí nio trocáyel (REZENDE, 1979; NUNES et alii, 1981; RIBEIRO e SENGIK, 1983; RODELLA et alii, 1983).

Várias hipóteses tem sido.sugeridas para expli car os efeitos da vinhaça na acidez trocável e valor $\mathrm{pH}$ do solo.

NUNES et alii (1981) atribuirám esse fenômeno à introdução de cátions básicos pela vinhaça. Neste aspecto, CA MARGO et alii (1983) observaram uma alta correlação entre a elevação do valor pH e o da saturação de bases do solo.

Também foi sugerido por NUNES et alii (1981) que a anaerobiose induzida pelos altos teores de carboidratos na 
vinhaça, poderá causar um decréscimo no potencial redox, pro vocando assim a redução de óxidos e hidróxidos de Fe e Al. Es ta ação redutora da vinhaça foi confirmada por LEAL et alii (1983), os quais empregaram doses até $800 \mathrm{~m}^{3} / \mathrm{ha}$ em um Podzóli co Vermelho Amarelo.

Por outro lado, RODELLA et alii (1983) verifica ram que os elementos $\mathrm{K}$, Ca e Mg estão presentes na fase líqui da da vinhaça, enquanto que $O N, P$ e $C$ encontram-se nas fases líquida e sólida, embora deva-se ressaltar, que cerca de $70 \%$ do $C$ e $50 \%$ do $N$ orgânico encontram-se na fase líquida (NUNES et alii, 1981). Segundo esses autores, O $N$ e o C nesta forma poderão sofrer rápida decomposição pelos microrganismos do so 1o, contribuindo dessa maneira paxa a elevação do valor $\mathrm{pH}$.

Segundo Asghar e Kanchiro (1977) citados por NU NES et alii (1981), as seguintes reações estão envolvidas no processo:

$$
\begin{aligned}
& \mathrm{R}-\mathrm{NH}_{2}+\mathrm{HOH} \cdot \frac{\text { hidrólise }}{\text { enzimätica }} \mathrm{R}-\mathrm{OH}+\mathrm{NH}_{3}+\text { energia } \\
& \mathrm{NH}_{3}+\mathrm{HOH} \longrightarrow \mathrm{NH}_{4} \mathrm{OH} \rightleftharpoons \mathrm{NH}_{4}^{+}+\mathrm{OH}^{-} \quad(\mathrm{pKb}=4,75)
\end{aligned}
$$

Com relação a diminuição da acidez trocável, RO DELLA et alii (1983) atribụiram esse fato à complexação do $\mathrm{Al}^{3+}$ pelo carbono orgânico. 


\section{b) Carbono, nitrogênio e relação $\mathrm{C} / \mathrm{N}$}

Entre os nutrientes encontrados na vinhaça, o carbono é o que se apresenta em maiores quantidades.

FERREIRA (1980) incubando solos de diferentes texturas com doses de vinhaça até $1600 \mathrm{~m}^{3} / \mathrm{ha}$, verificou dias após a aplicação, uma elevação no teor de carbono nos so los estudados.

GLORIA e MAGRO (1976) adicionando resíduos de usina e destilaria durante três anos consecutivos, também ob servaram um aumento do teor desse elemento. Entretanto quando a aplicação de vinhaça era interrompida, oś teores de $\mathrm{C}$ de cresciarn e voltavam aos valores originais.

CAMARGO et alii (1983) analisando amostras de um Latossolo Vermelho Escuro textura média, que foram retira dos de glebas tratadas por longo tempo com vinhaça e submeti das a intercalação de períodos de pousio, observaram que em apenas dois talhões. ocorreram acréscimos no valor de $C$.

Por outro lado, NUNES et alii (1981) e RIBEIRO e SENGIK (1983) utilizando respectivamente solos do Estado do Rio de Janeiro (Podzólico Vermelho Amarelo) e do Triângulo Mi neiro (Latossolo Vermelho Escuro e Latossolo Vermelho Amare 10), não verificaram alterações significativas no conteüdo de C desses solos após a aplicação de vinhoto. Este fato tem sí do atribuído à rápida decomposição da matéria orgânica exị tente na vinhaça (GLORIA e MAGRO, 1976), e ainda ao estímulo a oxidação biológica provocado pela adição do resíduo (RIBEI RO e SENGIK, 1983). 
Com relação as concentrações de $\mathrm{N}$ totài no solo, IIMA (1980) e NUNES et alii (1981) empregando doses de vinha ça até $600 \mathrm{~m}^{3} / \mathrm{ha}$ em um Podzólico Vermelho Amarelo, não verifí caram alterações nessa variável. Entretanto, ROSSIELLO et

alii (1981) utilizando solo semelhante ao citado anteriormen te constatou um aumento no teor de $\mathrm{N}$ total após 35 dias da aplicação de $1600 \mathrm{~m}^{3} / \mathrm{ha}$ de vinhaça.

CAMARGO et alii (1983) observaram um aumento considerável nas concentrações de $\mathrm{N}$ total do solo, estando es se fato diretamente relacionado com as alterações ocorridas nos teores de $C$.

Por outro lado as modificações nos teores desse macronutriente no solo poderão estar associadas aos processos de denitrificação e imobilização.

Neste sentido, AMARAL SOBRINHO et alii observaram que a aplicação de doses crescentes de vinhaça, acarretaram uma drāstica redução nos teores de $\mathrm{N}^{-\mathrm{NO}_{3}^{-}}$, com um simultâneo acúmulo de $\mathrm{N}-\mathrm{NO}_{2}^{-}, \mathrm{N}^{-} \mathrm{NH}_{4}^{+}, \mathrm{N}-\mathrm{NO}$ e $\mathrm{N}$ org̣ânico, indi cando que os processos predominantes no ciclo do nitrogênio foram os de denitrificação e imobilização. No tratamento que recebeu a dose mais elevada de vinhaça $\left(800 \mathrm{~m}^{3} / \mathrm{ha}\right)$ houve uma perda de $18 \%$ do $\mathrm{N}^{-\mathrm{NO}_{3}^{-}}$devido a denitrificação e uma redução de 27\% do nitrogênio mineral devido à imobilização. Segundo os autores, o acúmulo de $\mathrm{N}-\mathrm{NH}_{4}^{+}$pode ser atribuído à amonificá çao, processo que poderia ter sido facilitado, em vista da elevada quantidade de nitrogênio na fração solúvel da vinha 
ça, e/ou redução do $\mathrm{N}^{-\mathrm{NO}_{3}^{-}}$adiocionado a $\mathrm{N}-\mathrm{NH}_{4}^{+}$, a qual é favo recida em solos anaeróbicos e ricos em $C_{i}$ essa condição pode ter sido atingida com a aplicação das doses mais elevadas de vinhaça.

Com o propósito de estudar o efeito da adição de vinhaça nai lixiviação de nitrató e amônio, velLoso et alii (1982) incubaram um solo de textura arenosa com doses de vi nhaça até $400 \mathrm{~m}^{3} / \mathrm{ha}$, na presença e na ausência de nitrogênio e fósforo, procedendo em seguida à Iixiviação em colunas de per colação com volumes de ãgua equivalentes a 1,2 e 3 volumesporo. Os autores verificaram que enquanto os teores de nitra to lixiviados decresciam os de amônio aumenţavam, sendo es ses efeitos proporcionais as doses de vinhaça aplicadas. Atri buíram esse decréscimo nas concentrações de nitrato nos eflu entes, como em reflexo das perdas desse'nutriente por deni trificação. Por outro lado, o aumento do teor de amônio nos efluentes, pode ser devido a elevada concentração de potássio na solução, o qual passaria a ser preferencialmente adsorvido, deslocando assim, o amônio para a solùção do solo.

Outro aspecto que foi estudado por alguns pes quisadores, foram as alterações nas relações $\mathrm{C} / \mathrm{N}$ do solo, em fumção da aplicação de vinhaça.

Neste sentido; IIMA (1980) observou variações significativas na relação $\mathrm{C} / \mathrm{N}$ do solo, sendo as mesmas atri buídas aos acrëscimos nos valores de carbono. Entretanto, NU NES et alii (1981) não verificaram alterações nessa relação 
em um Podzólico Vermelho Amarelo.

A relação $C / N$, que na vinhaça varia de 16 a 22, atingiu valores médios entre 9 e 10 em solo tratado por um longo período de tempo com vinhoto, indicando ter havido um equilíbrio, sendo alcançada dessa forma, certa estabilidade da matéria orgênica (CAMARGo et alii, 1983).

c) Bases trocáveis, capacidade de troca de cátions e fósforo

A vinhaça face à sua composição química, apre sentando altos teores de potássio, médios teores de cálcio e magnésio e baixos teores de fósforo (ALMEIDA, 1962; GLORIA et alii, 1972; GLORIA et alii, 1973; RODELLA et alii, 1973; RODELLA e FERRARI, 1977), quando aplicađa ao solo poderá acar retar algumas alterações em suas propriedades quỉmicas.

Neste sentido, vários trabalhos evidenciaramque a aplicação de vinhaça no solo, tem promovido aumentos nas concentrações de potássio, cálcio, magnésio, capacidade de , troca de cátions, soma de bases e saturação em bases, sendo esses aumentos de maneira geral, proporcionais às quantidą dẹs do resíduo adicionadas (BRIEGER, 1977; AGUJARO, 1979 ; CAMARGO et alii, 1983; COLETI et alii, 1983; ORLANDO FILHO et alii, 1983; SENGIK, 1983).

A grande disparidade de concentração do $K$ em re lação aos outros elementós minerais na vinhaça, poderá ser 
preocupante, em função de desequilíbrios nutricionais que po derão advir.

Neste sentido, Bear et alii (1945) citados por MCheAN (1984) sugeriram para um solo "ideal" uma saturação de potássio de $5 \%$

Entretanto, trabalhos conduzidos por CAMARGO et alii (1983) e MAZZA (1985) em solos tratados por um longo pe ríodo de tempo com altas doses de vinhaça, evidenciaram que o sistema de troca estava ocupado com cerca de $30 \%$ de $\mathrm{K}$, portan to. bastante acima daquele valor considerado ideal.

Recentemente alguns pesquisadores começaram a se preocupar com a dinâmica dos íons $\mathrm{K}$, Ca e Mg no solo, após a aplicação de vinhaça.

NUNES et alii (1982) estudou o efeito de doses crescentes de vinhaça na lixiviação dos, íons $\mathrm{K}$, Ca e Mg, uti lizando-se de colunas, pelas quais fizeram percolar volumes crescentes de água. Foi verificado que os teores desses nu trientes nos efluențes aumentaram proporcionalmẹnte às doses de vinhoto aplicadas, independentemente do volume de água per colado. Os teores de $\mathrm{Ca}+\mathrm{Mg}$ lixiviados foram em torno de $0,5 \mathrm{meq} / 100 \mathrm{~g}$ de solo para o tratamento que recebeu a dose mais elevada de vinhaça $\left(400 \mathrm{~m}^{3} / \mathrm{ha}\right)$ juntamente com o maior vo lume de água percolado.

Segundo os autores citados anteriormente, o aú mento nos teores de $\mathrm{Ca}$ e Mg nos efluentes pode ser explicado pelas altas concentrações de $\mathrm{K}$ no solo, o qual atuaria deslo 
cando para a solução do solo parte dos ĩons Ca e Mg adsorví dos no complexo sortivo, tornando-os suscetíveis à lixivia ção. Os autores verificaram ainda, que o Mg é proporcional mente mais lixiviado que o $\mathrm{Ca}$.

CAMBUIM e CORDEIRO (1.986) estudando a ação da vinhaça na acumulação e lixiviação de nutrientes em amostras indeformadas de Areia Quartzosa distrófica, verificaram que a Iixiviação de $\mathrm{K}$, Ca e Mg é mais dependente do tempo de incu bação do que do volume de vinhaça utilizado. Amostragem de solo efetuada no mesmo dia da aplicação do resíduo, evidenciou aumentos nos teores trocáveis desses ejementos até a profun didade de $30 \mathrm{~cm}$.

ANDRIOJI (1982) estudando o movimento da vinha ga em colunas com um Podzolizado Lins e Marília var. Marília, constatou que a translocação do $\mathrm{K}$ até a,profundidade de $22 \mathrm{~cm}$ ocorre dentro de determinado limite de umidade $\left(\theta \geqslant 0,30 \mathrm{~cm}^{3}\right.$. $\mathrm{cm}^{-3}$, abaixo do qual o processo era paralisado.

LOBATQ (1984) em estudo semelhante, verificou que a translocação do cátion monovalente se dá até a profun didade de $25 \mathrm{~cm}$ quando $\theta>0,40 \mathrm{~cm}^{3} \cdot \mathrm{cm}^{-3}$.

Com rèlação ao fósforo, IJUNEs et alii (1981) e CAMBUIM e CORDEIRO (1986) verificaram un aumento nos teores desse nutriente no solo com a aplicação de vinhaça.

Contudo, trabalhos realizados em colunas de só 1o, demonstraram que a lixiviação desse elemento é inexpressi va (JEAL et alii, 2982; CAMBUIM e CORDEIRO, 1986) $x$ 
2.2. Efeitos da vinhaça nas propriedades físicas do solo

Considerando a constituição da vinhaça, indepen dente de seu tipo, o que predomina na fração dos sólidos des se resíduo é a matéria orgânica (GLORIA e ORLANDO FILHO, 1984). Portanto é evidente que sua adição ao solo corresponde, em primeirolugar, a uma fertilização orgânica devendo-se esperar teoricamente, nesse caso, todos os efeitos atribuídos à maté ria orgânica, quando adicionada aos solos: a) aumento da capa cidade de retenção de água devido à higroscopicidade, chegando a reter 4 a 6 vezes mais que o próprio peso; b) redução da densidade aparente e aumento da porosidade total do solo: c) formação de agregados capazes de reduzir a susceptibilidade à erosão e aumentar a capacidade de adsorção do solo; com a mo dificação da sua superfície específica;,d) efeitos sobre a consistência, permeabilidade, aeraçãc,e) temperatura e cor,re duzindo a plasticidade e coesão do solo, favorecendo opera ções de preparo (BEAUCLAIR, 1984).

Desta maneira, ALMEIDA (1952) um dos primeiros pesquisadores a se preocupar com os efeitos da vinhaça nas pro priedades físicas do solo, mencionou os efeitos favoráveis de sua aplicação nestas propriedades. Mais tarde,CESAR e MANFRI NATO (1954), evidenciaram o efeito conservacionista da aplica ção da vinhaça, devido as modificações da estrutura do solo ocasionadas, principalmente, pela matéria orgânica, tornandoa mais granular com aumento da porosidade não cápilar. RANZ $\underline{A}$ 
NI (1956), em condições de laboratório, utilizando-se de a l tas doses de vinhaça verificou que esta provocou um aumento da porosidade tótal e na capacịdade máxima de retenção de āgua do solo.

Por outro lado, REZENDE (1979) estudando ' os efeitos de doses crescentes, de vinhaça $\left(0-420 \mathrm{~m}^{3} / \mathrm{ha}\right)$ em algu mas propriedades de um solo Aluvial do Estado do Rio de Janeí ro, não constatou alterações na porosidade, na capacidade de retenção de água e no estado de agregação do solo.

Em um Latossol Vermelho Escuro - textura média tratado com $720 \mathrm{~m}^{3} / \mathrm{ha}$ de vinhaça diluída LEME et alii (1980) constataram que a vinhaça teve um comportamento diferente na capacidade de retenção de ãgua, em função das tensões que a āgua se encontra retida. Resultados semelhantes foram obtidos por ROSENFELD et alii (1981) em um Latossolo Roxo eutrófico que recebeu $1000 \mathrm{~m}^{3} / \mathrm{ha}$ de vinhaça.

Entretanto CAMARGO et alii (1983), embora tives sem constatado um melhor estado de agregação do solo Latossol Vermelho Escuro - textura média, que recebeu vinhaça por um , longo período de tempo (10 anos), este não foi suficiente pa ra promover incrementos nos valores de água disponível $(-1 / 3$ a $-1 / 5$ atm) do solo.

Contrariando estes resultados MAZZA (1985) veri ficou que aplicações maciças de vinhaça por longo período de tempo (20 anos) podem aumentar o armazenamento, o intervalo de 
água disponível do solo e provocar o deslocamento deste para nĨveis superiores de umidade. Entretanto aplicações comer ciais não provocaram alterações em tais características.

Com relação aos efeitos da vinhaça nos estados

" de floculação e dispersão da argila dos solos RIBEIRO et alii (1983) verificaram que esta atua, em relação a āgua, como dis perșante nos solos de textura média e como floculantes nos so los de textura argilosa. Conforme os autores, os solos de tex tura argilosa, com a CTC da fração argila bem menor, indica menor atividade dos materiais presentes nessa fração. Conse quentemente, espera-se que a dupla camada da fração argila desses solos ofereça menor resistência à compressão, quando colocado outros cátions na solução, o que reśultará na sua floculação. No solo de textura média e de argila mais ativa, haveria maior resistência a compressão. Uma dupla camada mais espessa daria à fração argila maior intensidade de dispersão. Observaram ainda que a vinhaça com maior concentração de cá tions, apresentou menor efeito de dispersão, em todos os so los estudados (cinco oxissolos). Concluiram portanto, que 0 efeito de dispersão ou de floculação da argila dos solos se 'gue, em linhas geraìs, os modelos teóricos clássicos dependen do da concentração e do balanço de cátions na vinhaça, além da natureza da fração argila contida nos solos.

Estes resultados foram confirmados por RIBEIRÓ \& SENGIK (1983) incubando amostras de Latossolo Vermelho Escu ro textura média e de Latossolo Vermelho Amarelo muito argilo 
so com diferentes doses de vinhaça $\left(0-180 \mathrm{~m}^{3} / \mathrm{ha}\right)$. Observaram que as menores doses de vinhaça (menor concentração de tions) promoveram floculação da argila, ao passo que doses maiores tiveram efeitos de dispersão.

Por outro lado, resultados contrários a estes foram obtidos por SENGIK (1983), aplićando doses de 0-50-100200 e $400 \mathrm{~m}^{3} /$ ha de vinhaça em amostras de Latossollo Vermelho Amarelo argiloso distrófico e de Podzólico Vermelho Amarelo câmbico textura média distrófico. Os autores não observaram alterações nos teores de argila natural independente das do ses de vinhaça utilizadas. Devido ao alto teor de potássio con tido na vinhaça, aplicações, principalmente, de quantidades deste resíduo podem alterar as condições de salinidade do so 10, especialmente de sais formados a partir deste elemento, e consequentemente promover alterações na condutividade elé trica do solo.

Dessa maneira elevação nos valores desta pro priedade, em função da aplicação de doses crescètes da vinha Ça no solo tem sido constatado por RANZANI 91956), REZENDE (1979), MAZZA (1985), ROSSIELLO et alii (1981), SANTOS et alii (1981). Em solos de diferentes texturas que receberam quantidades variáveis de vinhaça, FERREIRA (1980) constatou que estes foram salinizados (C.E. $\geqslant 4,0$ mmos $/ \mathrm{cm}$ a $25^{\circ} \mathrm{C} ;$, no extrato saturado USDA, 195i) a diferentes níveis de vinhaça. Em vista disso relatou que a aplicação da vinhaça ao solo, deve ser feita levando-se em consideração, não apenas a quan 
tidade e a concentração de sais contidos na mesma, mas princi palmente as propriedades do solo.

Por outro lado, LEME et alii (1980), BAPTISTELA et alii (1981) e ROSENFELD et alii (1981) em estudos ' sobre aplicação de vinhaça diluída por aspersão em oxissolos culti vados com cana-de-açúcar, consideraram que as : precipitações pluviométricas tem também ṣuita influência nas concentrações de sais contidos nos solos. Assim, constataram aumentos nọs valores de condutividade elétrica logo após a aplicação do re síduo, retornando-os aos níveis iniciais após o período chuvo so. Verificaram ainda, apesar da elevação nos valores de con dutividade elétrica no período seco, estes estão abaixo do Indice salino preconizado como 2,0 mmhos $/ \mathrm{cm}$ a $25^{\circ} \mathrm{C}$ pela As sociação Açucareira Sul Africana (S.A.S.A.) conforme citado por ORLANDO FILHO e ZAMBELLO JUNIOR (1980).

Os autores atribuíram a diminuição nos valores da condutividade elétrica à lixiviação dos constituintes quí micos da vinhaça através do perfil do solo, no período chuvo so e à absorção deste nutriente pelas plantas na época de maior desenvolvimento vegetativo.

Entretanto, em glebas de uma área homogenea de Lątossolo Vermelho Escuro - textura média, que foram tratadas por longo tempo com diferentes quantidạdes de vinhaça, e, in tercalados com períodos de repouso do solo, CAMARGo et a]ii (1983) observaram que o comportamento dos valores da conduti vidade elétrica é variävel. Assirn, nas glebas A'que recebeu 
$2.800 \mathrm{~m}^{3} / \mathrm{ha}$ de vinhaça nos anos 1970-74 e 79 , na c $2.800 \mathrm{~m}^{3} /$ ha nos anos 1970-74 e na $D$ que. recebeu $4.300 \mathrm{~m}^{3} / \mathrm{ha}$ nos anos 1975-78 os valores de condutividade elevaram-se ao longo do perfil do solo, o que foi atribuído em grande parte ao aumen to da saturação em potássio, cuja correlação com aqueles valo res, mostrou um coeficiente $r=0,75$, devido à elevação no teor de sais livres ricos neste elemento. Os autores menciona ram ainda que apesar das glebas estarem localizadas numa re gião chuvosa, pelo menos nas glebas A e C a condutividade elẹ trica alcance valores que podem prejudicar algumas culturas sensíveis à salinidade.

Por outro lado, ORLANDO FILHO et alii (1983), em estudo exploratório sobre os efeitos da aplicação prolongada da vinhaça (20 anos) nas propriedades químicas de vários so los da ordem oxissol de grande ocorrência no Estado de são Paulo, não observaram efeitos prejudiciais ao solo, como acū mulo de sais na camada arável ou em horizontes de sub-superfí cie. 


\section{MATERIAL E METODOS}

\subsection{Caracterização da área de estudo}

O experimento foi realizado na área experimen tal da Faculdade de Ciências Agrārias e Veterinárias - UNESP, no município de Jaboticabal-SP, que se situa entre $21^{\circ} 15^{\prime} 22 "$ de latitude $s$ e $48^{\circ} 18^{\prime} 58^{\prime \prime}$ de longitude ' $w$.

O clima é do tipo Cwa, segundo a classificacão Köppen, denominado mesotérmico de inverno seco. A temperatura do mês mais quente é superior a $22^{\circ} \mathrm{C}$ e a do mês mais frio é inferior a $18^{\circ} \mathrm{C}$. A precipitação média anual é de $1280 \mathrm{~mm}$, com distribuição mostrando maior concentração no período de outu bro à março, sendo mais seco no período de abril à setembro.

3.2. Solo

Instalou-se o ensaio em um Latossolo Vermelho 
Escuro A moderado textura média distrófico, sendo que algumas características químicas e físicas do mesmo encontram-se na Tabela 1 .

3.3. Delineamento experimental

Utilizou-se do delineamento experimental em blo cos ao acaso com três repetições, combinando-se cinco dosẹs de vinhaça $\left(D_{1}=0 ; D_{2}=150 ; D_{3}=300 ; D_{4}=600\right.$ e $D_{5}=1200$ $\left.\mathrm{m}^{3} / \mathrm{ha}\right)$, duas condições a saber: com cobertura plástica $\left(\mathrm{C}_{1}\right)$ e sem cobertura plástica $\left(C_{2}\right)$ e três épocas de amostragem de solo $\left(E_{1}=1 \underline{a}\right.$ amostragem, $E_{2}=2 \underline{a}$ amostragém, $E_{3}=$ amostra gem) •

As parcelas apresentavam uma área de $28 \mathrm{~m}^{2} \quad(5,0$ x 5,6 m) e eram separadas entre si por çarreadores de $2 \mathrm{~m}$.

3.4. Vinhaça: composição e processo de aplicação

As doses de vinhaça foram parceladas em três ve zes, em partes iguais, sendo a primeira aplicação realizada de 21 a 24 de fevereiro, a segunda de 10 a 15 de junho e a tercejra de 20 a 25 de setembro de 1983.

A composição química das vinhaças utilizadas en contra-se na Tabela 2.

Para a aplicação das doses parciais de vinhaça, utilizou-se de dois tambores metälicos com capacidade indivi dual de cerca de 200 l. Em cada um deles, acoplou-se um bico de regador atravês de um tubo de latex com diâmetro de $3 / 4$ de 


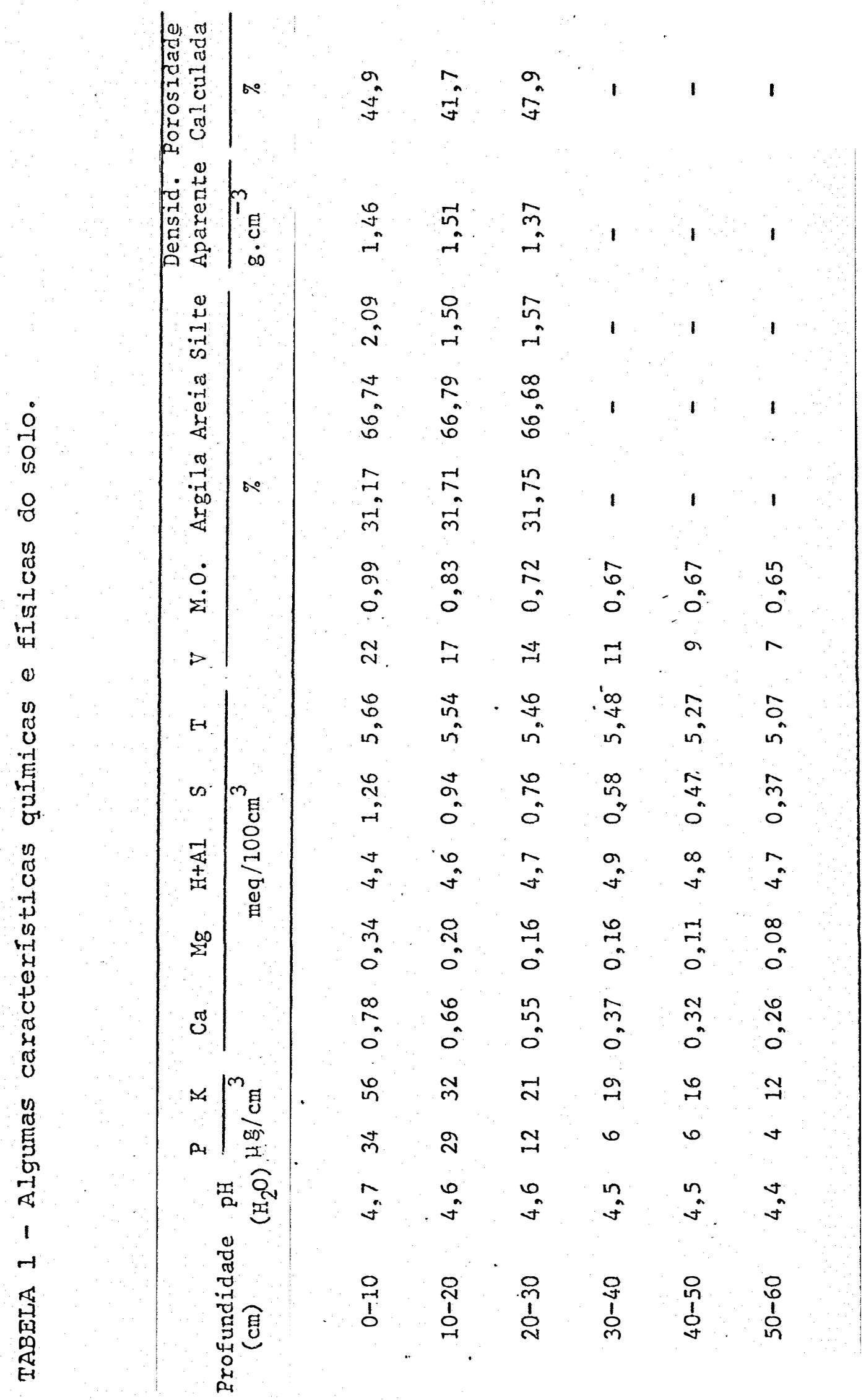


polegada. Entre esse tubo de latex e o bico do regador, colo cou-se um tubo de metal, com comprimento suficiente a evitar - pisoteio na parcela durante a aplicação.

O controle das doses de vinhaça para cada tratą mento, foi realizado através de um medidor de volume, acopla do na parte externa dos tambores.

Estes tambores foram colocados a uma altura de três metros ern relação a superfície do texreno, sobre um su porte de madeira, com o objetivo de se obter uma diferença de pressão suficiente, que permitisse uma distribuição homogênea da vinhaça nas parcelas.

TABELA 2 - Dados analiticos da vinhaça referente a cada apli cação.

Determinação

$\triangle P L I C A C \tilde{A} O$

Primeira

Segunda

10 a $15 / 6$

Terceira

$\mathrm{kg} / \mathrm{m}^{3}$

\begin{tabular}{|c|c|c|c|}
\hline $\mathrm{N}$ & 0,34 & 0,24 & 0,39 \\
\hline $\mathrm{P}_{2} \mathrm{O}_{5}$ total & 0,13 & 0,14 & 0,16 \\
\hline $\mathrm{K}_{2} \mathrm{O}$ & 0,80 & 1,73 & 1,98 \\
\hline $\mathrm{K}_{2} \mathrm{O}$ livre & 0,80 & 1,73 & 1,94 \\
\hline $\mathrm{CaO}$ & 0,25 & 0,50 & 0,51 \\
\hline $\mathrm{MgO}$ & 0,16 & 0,30 & 0,29 \\
\hline Mat. orgânica & 8,91 & 17,02 & 19,11 \\
\hline $\mathrm{pH}$ & 4,44 & 4,39 & 4,45 \\
\hline
\end{tabular}


3.5. Cobertura plástica

Nos tratamentos denominados $C_{l}$, foi utilizada uma cobertura com plástico transparente $(0,5 \mathrm{~mm}$ de espessura), com o intuito de evitar a presença da água das chuvas no solo dessas parcelas.

Com a finalidade de manter o fluxo da água do solo para a atmosfera, esta cobertura era removida manualmen te nos dias em que não ocorriam precipitações pluviométricas.

3.6. Coleta dos dados

\subsubsection{Amostras com estrutura indeformada}

Utilizando-se de um amostrador semelhante ao descrito por UHLAND (1949), amostras de solo cuja estrutura foi mantida indeformada foram coletadas em cada parcela, nas camadas de 0-10, 10-20 e 20-30 cm, nos dias 17 e 18/5; 14 e $15 / 9$ e $22 / 12 / 1983$.

3.6.2. Amostras com estrutura deformada

As amostras de solo com estrutura deformada fo ram coletadas nas camadas de 0-10, 10-20, 20-30 e 50-60 $\mathrm{Cm}$, nas mesmas épocas citadas no item 3.6.1.

$\mathrm{Na}$ terceirạ amostragem (21 e 22/12/1983) tambēm 
foram retiradas amostras com estrutura deformada nas camadas de $30-40$ e $40-50 \mathrm{~cm}$.

Para acompanhar a variação de umidade em função da profundidade e do tempo, foram coletadas amostras do solo nas profundidades médias de $\mathbf{z}=5,15,25$ e $55 \mathrm{~cm}$, nos dias $25 / 02 ; 15 / 03 ; 30 / 03 ; 15 / 04 ; 29 / 04 ; 19 / 05 ; 07 / 06 ; 29 / 06 ; 15 / 07$; $01 / 08 ; 19 / 08 ; 02 / 09 ; 16 / 09 ; 28 / 09 ; 20 / 10$ e 04/11/1983.

\subsection{Análises físicas}

Para verificar os efeitos dos tratamentos utili zados nas características físicas do solo foram realizadas as seguintes determinações :

a) Densidade global $\left(\mathrm{g} \cdot \mathrm{cm}^{3}\right)$ : foi determinada empregan do-se a relação massa cio solo seco (Ms) sobre volume total da amostra (Va).

b) Porosidade total calculada (\%): foi determinada atravēs da expressão:

$$
\alpha_{c}=\left(1-\frac{\rho g}{\rho p}\right) \cdot 100
$$

onde:

$\alpha_{c}=$ Porosidade total calculada

$\rho g=$ Densidade global

$\mathcal{L} p=$ Densidade das" partículas 
c) Densidade das particulas $\left(\mathrm{g} \cdot \mathrm{cm}^{-3}\right)$ : foi determinada utilizando-se álcool etílico, de acordo com metodologia des crita em EMBRAPA (1979).

d) Macroporosidade e microporosidade (은 foram deter minadas tendo-se como referência a tensão de $60 \mathrm{~cm}$ de : coluna d'água, mediante o emprego do funil de placa porosa, segundo método descrito por vomocrl (1965).

e) Granulometria (\%): foi realizada utilizando-se do método da pipeta, descrito por Kilmer e Alexander (1949) modi ficado por DAY (1965).

f) Argila natural (\%) e grau de floculação $(\%)$ : os va lores da argila natural. foram determinados de acorảo com meto dologia descrita em EMBRAPA (1979), enquanto que o grau de floculação foi determinado atravēs da seguinte expressão:

$$
G F \doteq \frac{A t-A n}{A t} \cdot 100
$$

onde:

$\mathrm{GF}=$ Grau de floculação

At $=$ Argila total

An $=$ Argila natural

g) Condutividade elétrica (mnhos. $\mathrm{cm}^{-1}$ a $25^{\circ} \mathrm{C}$ ): foi determinada no extrato de solo, com rẹ̣ação solo: água, de 1:I, conforme metodologia descrita em EMBRAPA (1979). 
3.8. Anălises químicas

As análises químịcas para fins de fertilidade do solo, foram realizadas de acordo com métodos descritos por RAIJ e QUAGGIO (1983), exceto a determinação do valor pH que foi realizada em água (RAIJ e ZULLO, 1977).

3.9. Umidade

A umidade foi determinada pelo método gravimé trico e expressa em base de volume $\left(\mathrm{cm}^{3} . \mathrm{cm}^{-3}\right)$, utilizando-se de valores médios de densidade aparente em cada camada. 
4. RESULtados E DISCUSS $\widetilde{O}$

Os resultados referentes as propriedades quimi cas do solo, nas diferentes profundidades, encontram-se nas Tabelas 3 a 8 .

4.1. Valor $\mathrm{pH}$ do solo; concentrações de $H+A l$ e fósforo

Observa-se através das Tabelas 3 a 8 que isola damente as doses de vinhça não alteraram significativamente os valores $\mathrm{pH}$ do solo.

Esse fato pode ser atribuído ao tempo transcor 'rido entre as aplicações de vinhaça e as amostragens de solo realizadas (REZENDE, 1979; LIMA, 1980).

Segundo RODELLA et alii (1983) os efeitos da vinhaça no pH do solo são efêmeros, voltando aos valores 'ori ginais após um determinado período de tempo.

Por outro lado, acredita-se que as determina ções do pH em água tenham sofrido interferência pela presença 


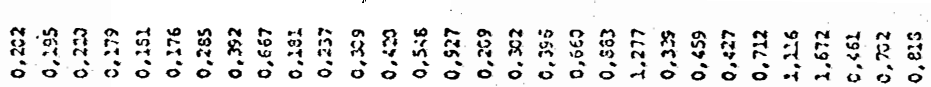

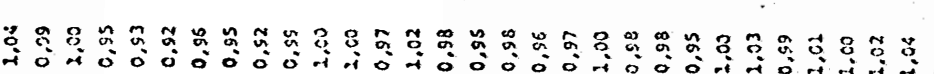

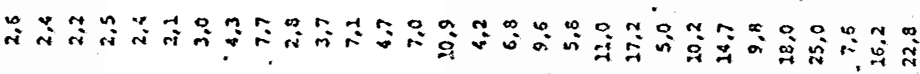

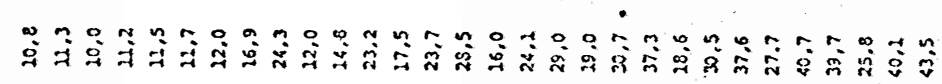

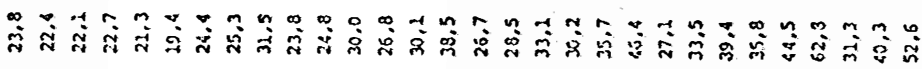

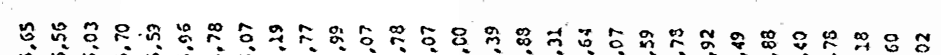

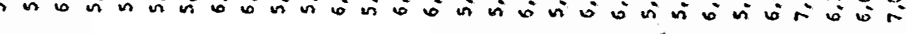

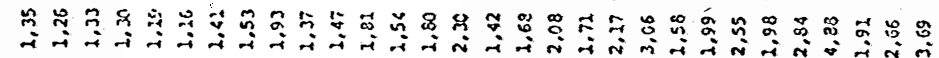

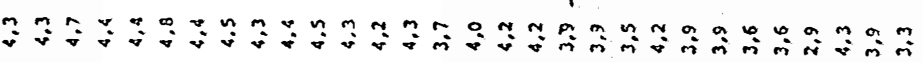

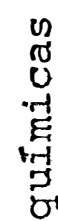
(2)

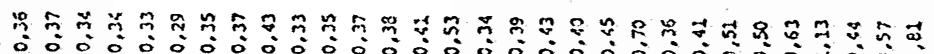

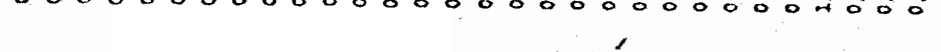

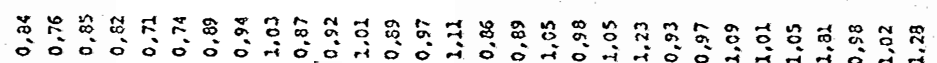
in गे

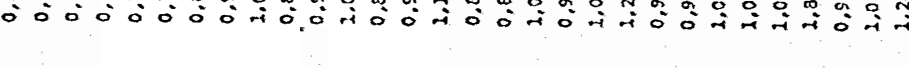

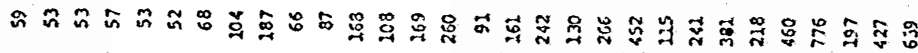

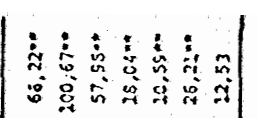

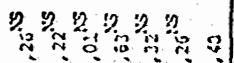

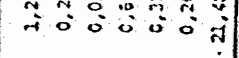

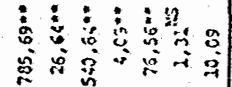

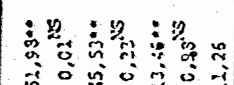

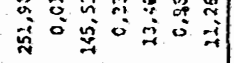

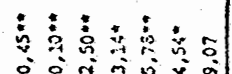
过牙的的 :

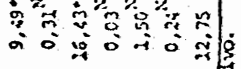

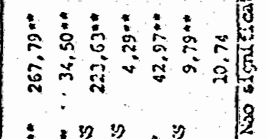
:

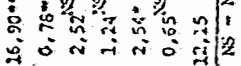
: : : :

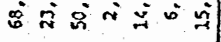
: की 1 m 孚 国 E 
ro
4
0
겅
0

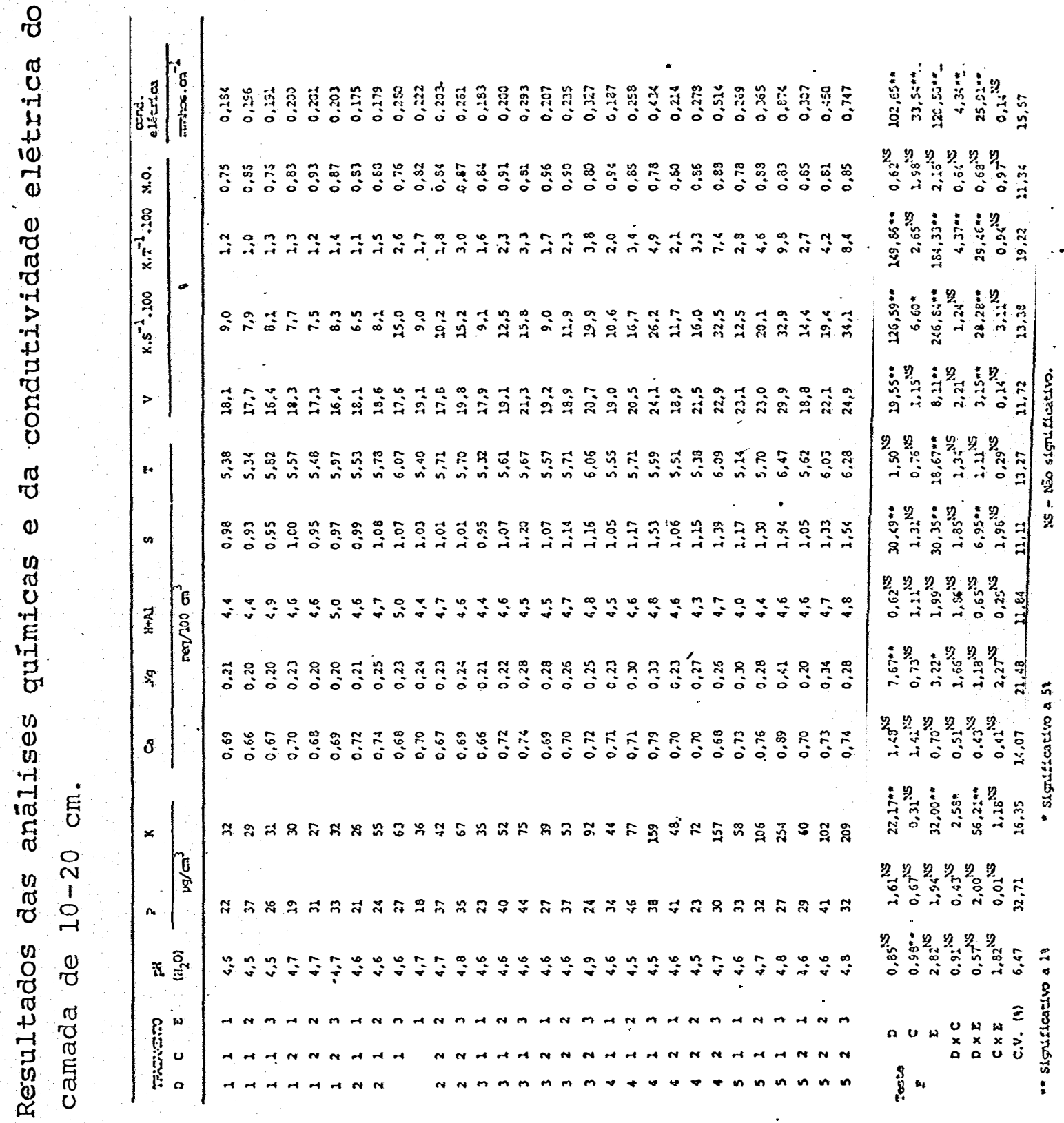

1
+
4
4
9
9
9 
0
0
0
-1
0

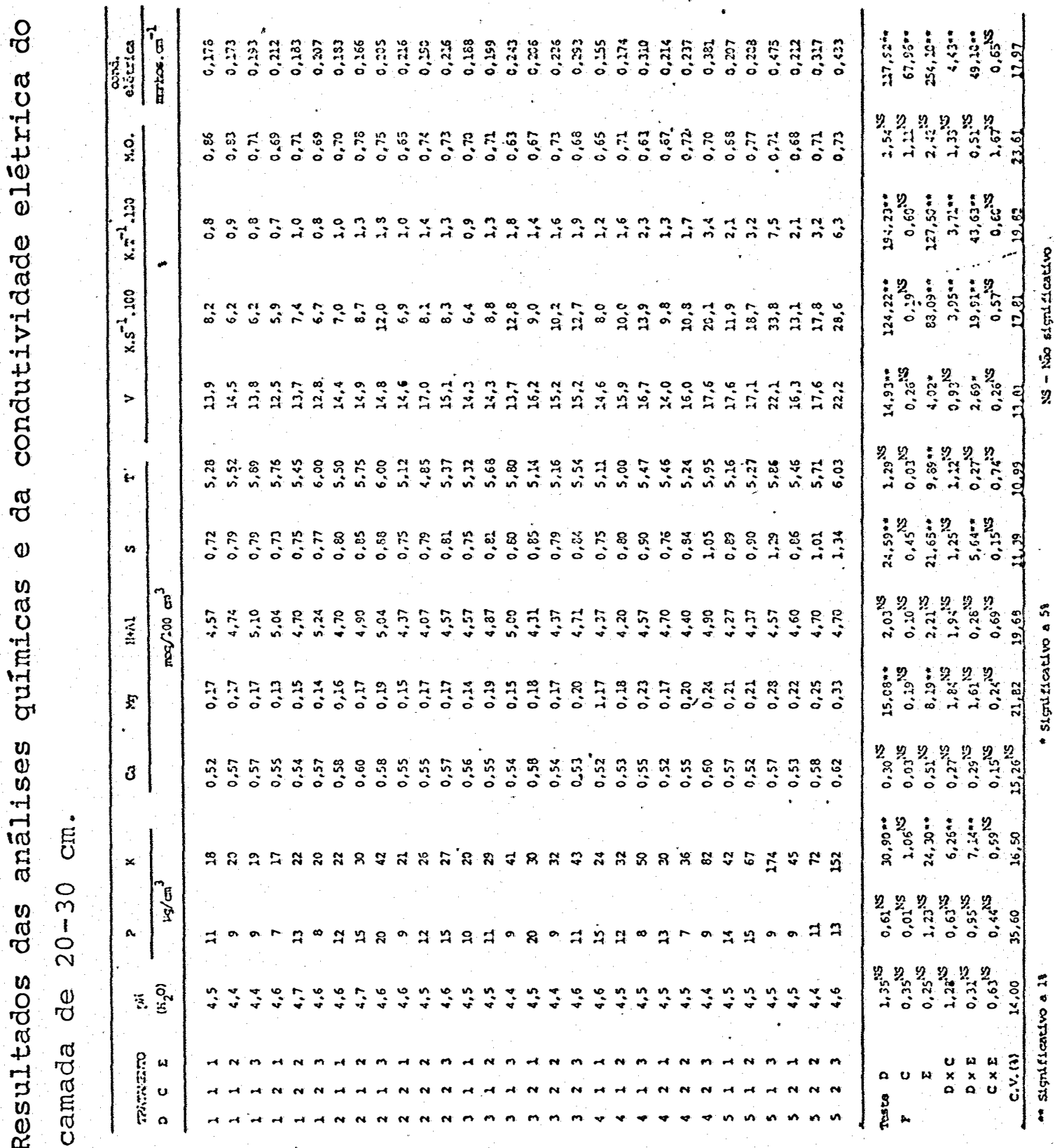
1

in

点

䁬 


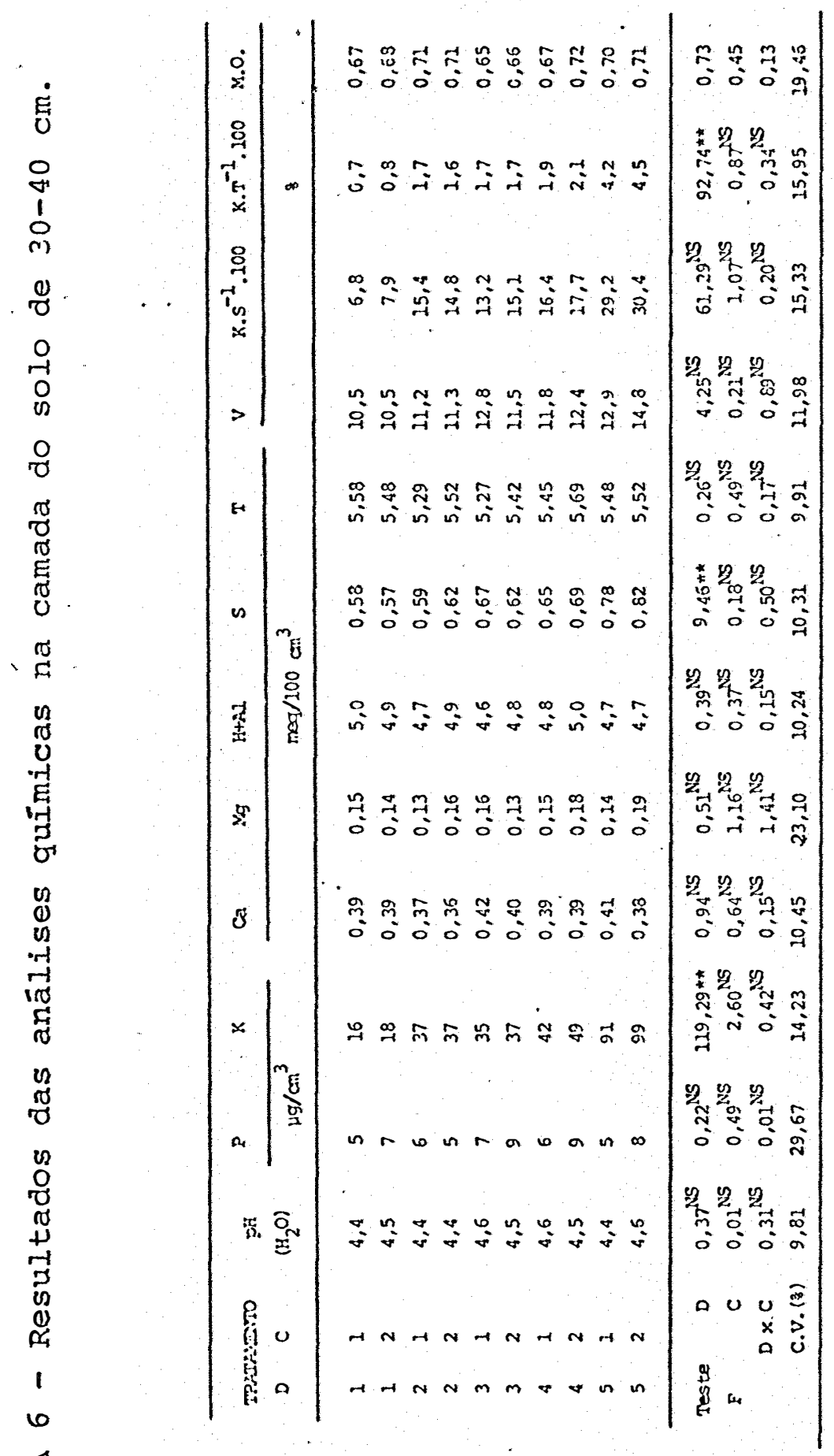

舀 


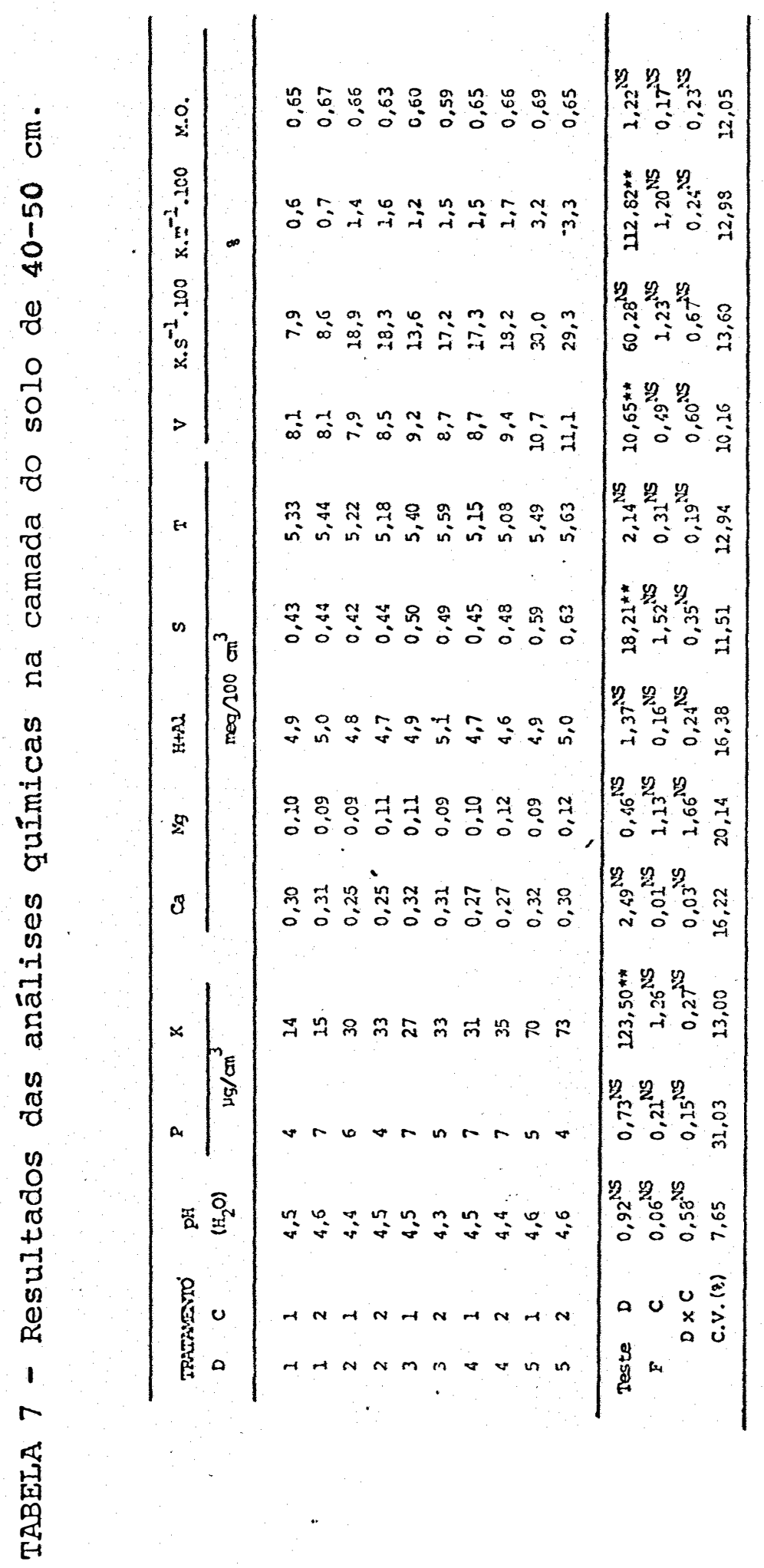




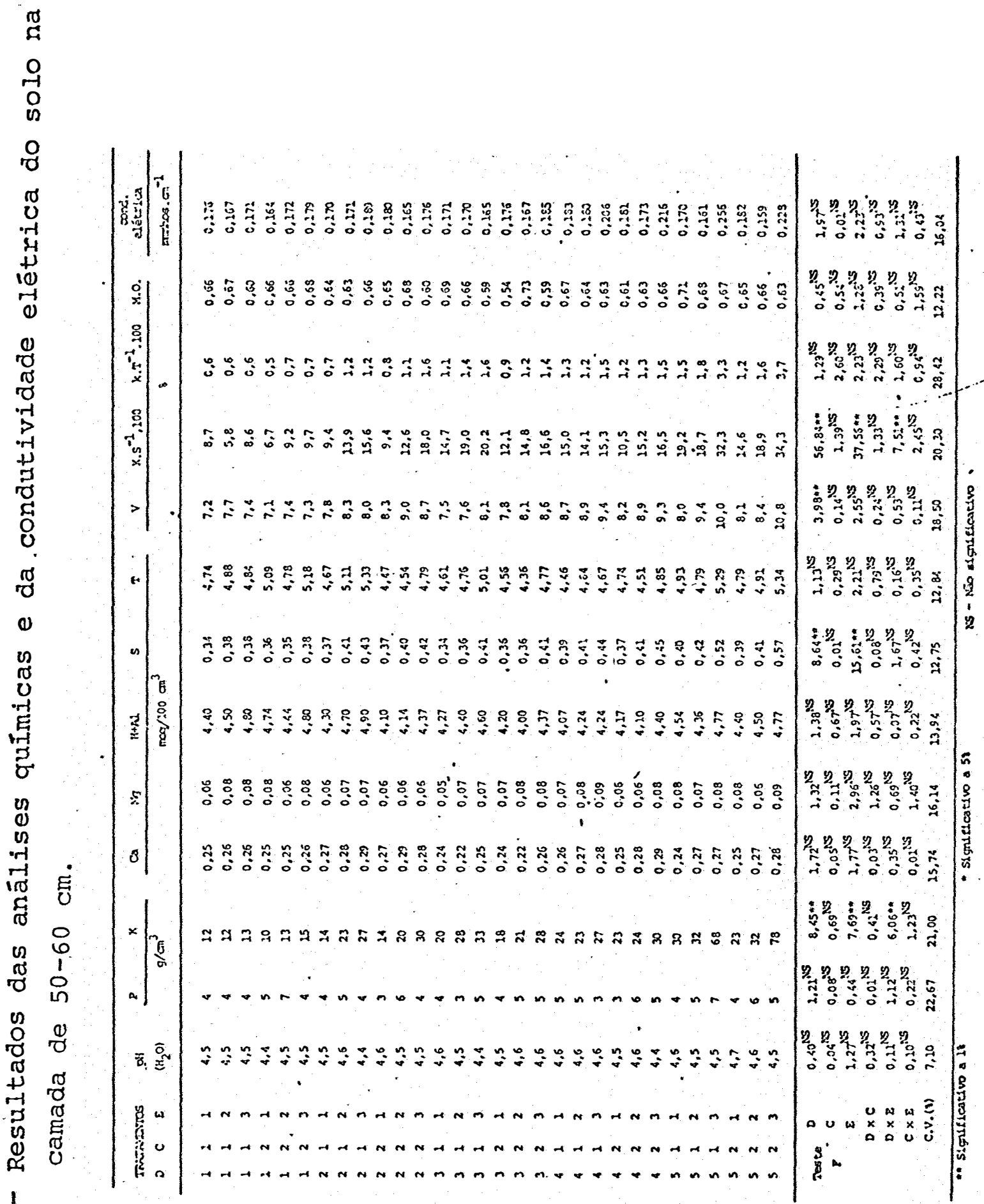

点 
de sais, e em função disso, os seus valores foram reduzidos. As altas concentrações de sais, principalmente na presença das doses mais elevadas de vinhaça, podem ser visualizadas indire tamente, nos dados de condutividade elétrica apresentados nas Figuras 21 e 22 .

Essa hipótese apresenta respaldo quando se ob sèrva as Figuras " 1 e 22, onde se nota respectivamente, uma redução nas concentrações de $\mathrm{H}+\mathrm{Al}$ e um aumento na saturação em bases, em função das doses de vinhaça aplicadas.

Segundo CATANI e GALLO (1955) o valor pH do so lo ê uma consequência da saturação em baseś, isto é, ele de pende não somente da acidez potencial como támbém da soma de bases.

Neste trabalho não foi vełificada uma relação direta entre essas variáveis, demonstrando a pouca confiabili dade da determinação do pH em āgua, quando na presença de ele vada concentração de sais.

As explicações mencionadas anteriormente, podem ser também consideradas para justificar o efeito não signifi cativo das. épocas de amostragem no valor $\mathrm{pH}$ do solo, visto que as mesmas exprimem o efeito cumulativo das doses de vinha ça.

$$
\text { Nota-se aindà na Tabela } 3 \text { e Figura 2, que ás }
$$

doses de vinhaça comportaram-se de maneira diferente, em fun ção da presença ou ausência de cobertura plástića linteração 


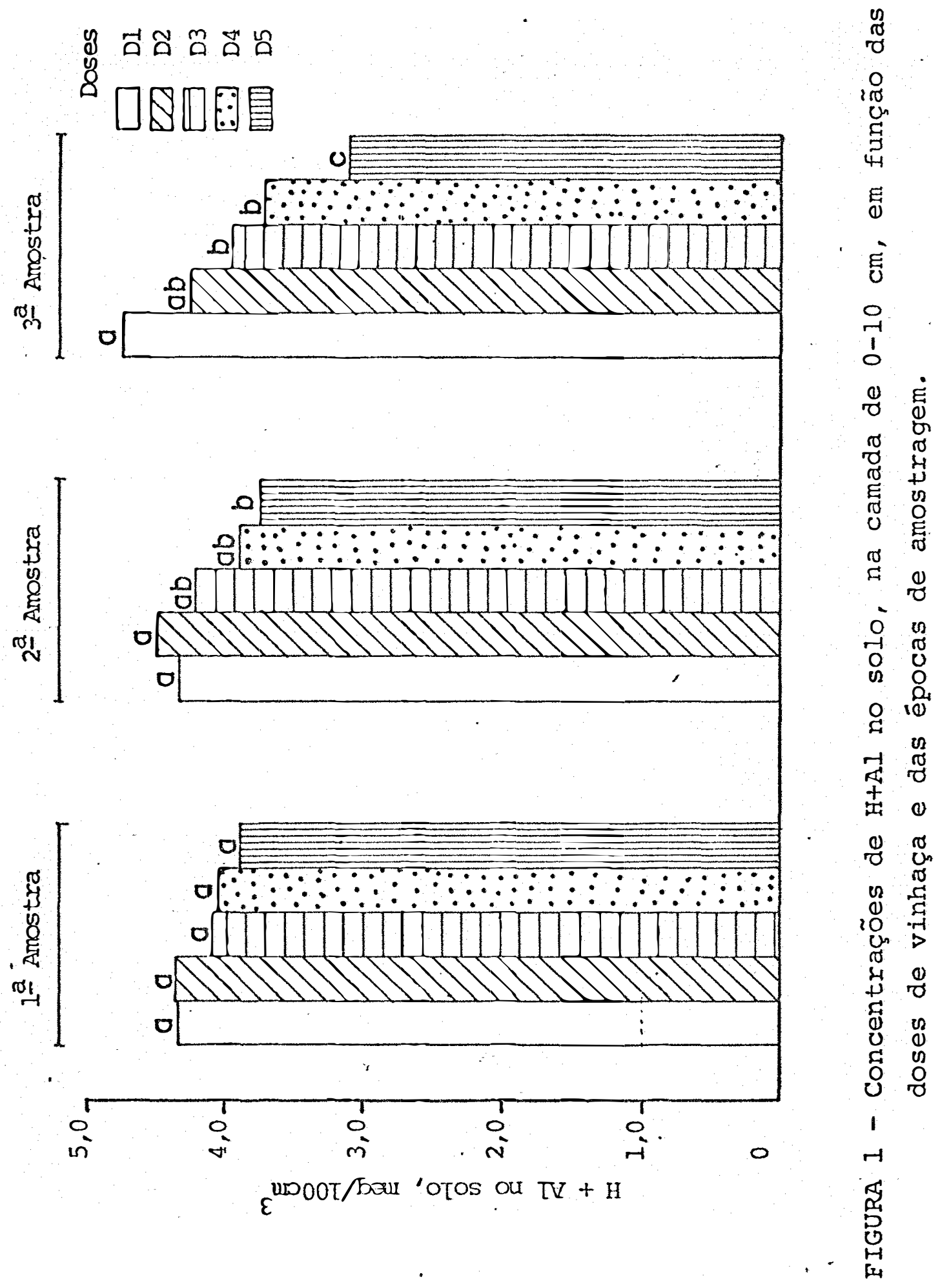




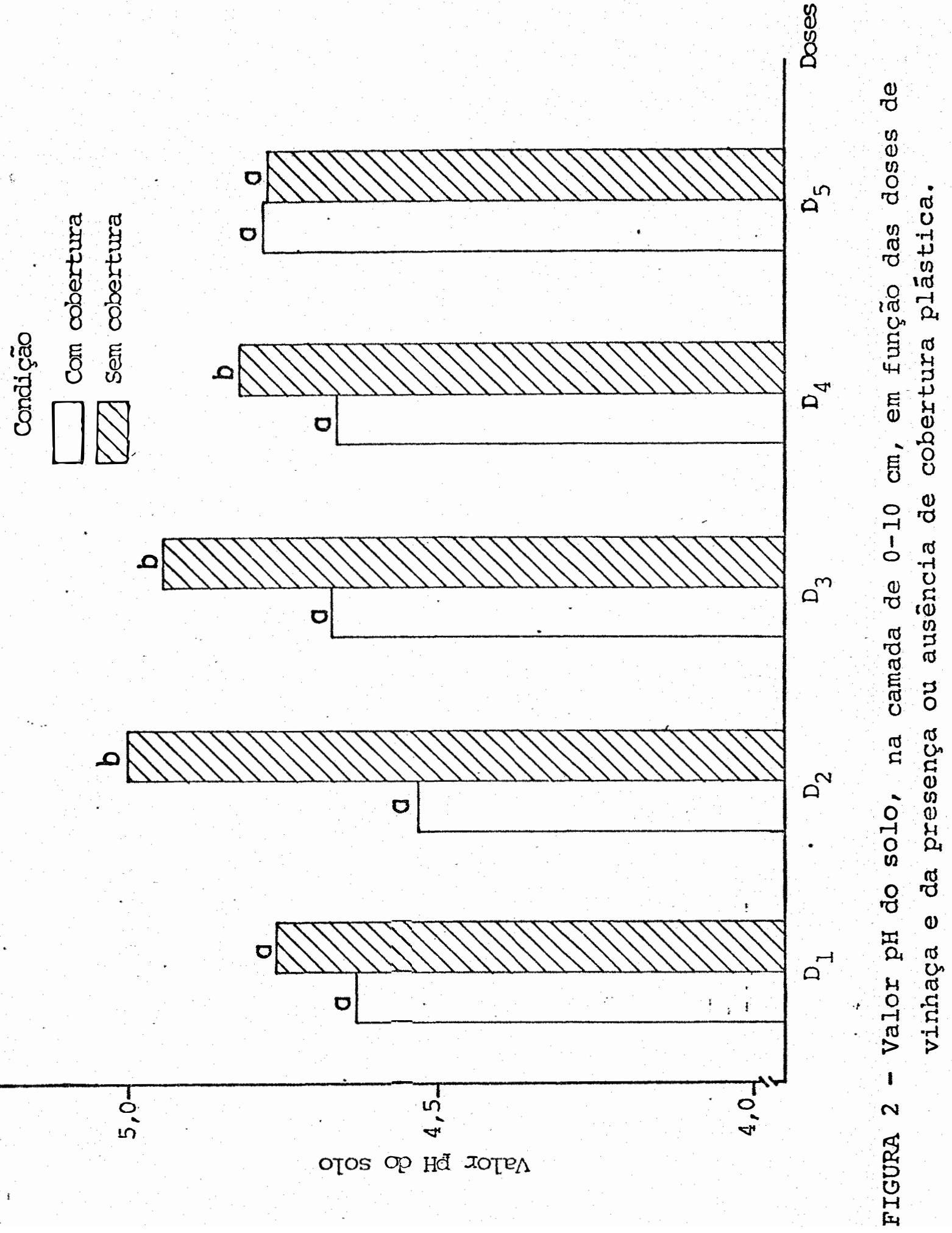


D X C significativa), observando-se de um modo geral, valores pH mais elevados nos tratamentos que receberam as āguas das chuvas.

Entretanto, quando se compara esses resultados com aqueles contidos na Figura 18, verifica-se uma contradi ção ou seja, os valores de pH são mais elevados nos tratamen tos que apresentaram uma mẹnor saturação em bases.

Como já foi exposto anteriormente, acredita-se que os dados obtidos sejam consequência das interferências na determinação do $\mathrm{pH}$ em ãgua.

Examinando-se ainda das Tabelas 3 a 8 , verifi ca-se que as concentrações de fósforo não foram afetadas sig nificativamente pelos tratamentos, discordando assim, dos re sultadós obtidos por NUNES et alii (1981) e CAMBUIM e CORDEI RO (1986).

4.2. Teor de matēria orgânica do solo

Verifica-se atravês das Tabelas 3 a 8 , que os , teores de matéria orgânica nas diferentes camadas, não foram afetados significativamente pelas dọses de vinhaça, condições e épocas de amostragem.

A hipōtese da translocação do $C$ através do pẹr fil do solo, devido ao fato de aproximadamente $70 \%$ do mesmo estar contido na fase líquida da vinhaça (RODELLA et alii, 1983), não se confirmou hesse experimento, discordando dos 
resultados obtidos por SENGTK (1983).

Desta maneira, uma das explicações plausíveis pa ra o fato ocorrido, pode estar associado ao processo de decom posição da matéria orgânica. Segundo RASOVSKY (1973), dos com ponentes orgânicos da vinhaça, os açücares simples, na sua maioria pentoses, são os mais abundantes, sendo os mesmos fa cilmente decompostos pelos microrganismos do solo (LIMA, 1980). Portanto, apesar da aplicação desse efluente in troduzir quantidades significativas de carbono no solo, por outro lado este efeito seria anulado pelas modificações impos tas no meio, favorecendo o desenvolvimento de microrçanismos (CAMARGO, 1954; CALDAS, 1960b; ALMEIDA, 1953; LIMA, 1980), os quais promoveriam uma maior decomposição da matéria orgânica adicionada (CALDAS, 1960b; RIBEIRO e SENGIK, 1983; NEVES et alii, 1983; SENGIK, 1983).

Por outro lado, o efeito não significativo das épocas de amostragem nos teores de matéria orgânica do solo, parece mostrar a velocidade do processo de decomposição da mesma, uma vè que as amostragens foram realizadas cerca de 90 dias após cada aplicação de vinhaça.

4.3. Cálcio, magnésio e potássio do solo

Em virtude da presença de Ca, Mg e Kna vinhaçá, espera-se que a aplicação desse resíduo promova uma elevação nos teores desses nutrientes no solo. 
Contudo para o cálcio, esse aumento somente foi verifiaado na camada de 0-10 cm (Figura 3), na terceira amos tragem quando se aplicou $1200 \mathrm{~m}^{3} / \mathrm{ha}$ de vinhaça.

Com relação ao magnésio, verifica-se através das Tabelas 3 a 5 e Figura 4, que as concentrações desse cātion divalente aumentaram significativamente até a profundidade de $30 \mathrm{~cm}$, sendo esses efeitos mais pronunciados quando se apli cou as doses mais elevadas de vinhaça.

O efeito cumulativo das doses de vinhaça é evi denciado na Figura 5, onde o comportamento das doses foi di ferente dentro das épocas de amostragem (interação D x E sig nificativa). Nota-se que os teores de Mg aumentaram significa tivamente nessa camada, principalmente quando se utilizou do ses superiores a $600 \mathrm{~m}^{3} / \mathrm{ha}$ de vinhaça.

De maneira análoga ao $\mathrm{Ca}$ é $\mathrm{Mg}$, as doses de vi nhaça tambëm promoveram incremento significativos nos teores de potássio trocável. Esses aumentos foram verificados em to das as camadas estudadas, sendo esses efeitos proporcionais às doses de vinhaça aplicadas, particularmente até a profundidade . de $30 \mathrm{~cm}$ (Figura 6).

Incrementos nas concentrações de $\mathrm{Ca}, \mathrm{Mg}$ e $\mathrm{K}$ no salo, tambēm foram observados por BRIEGER (1977), MAGRO (1978), AGUJARO (1979), FERREIRA (1980), NUNES et alii (1981), COLETI et alii (1983), ORLANDO FILHO et alii (1983), RIBEIRO e SENGIK (1983), SENGIK (1983) e CAMBUIM e CORDEIRO (1986). 
8
8
8

ه
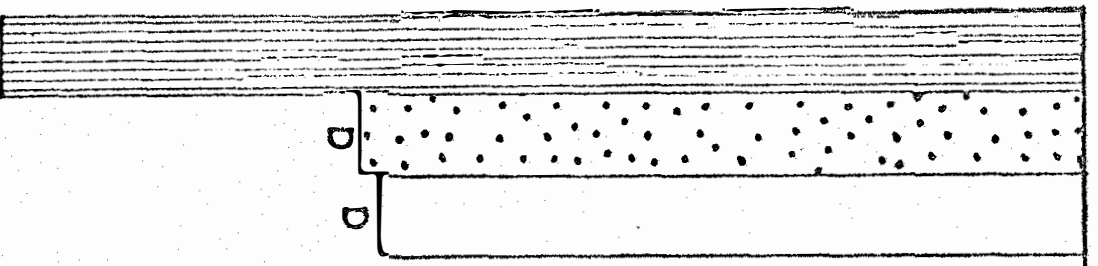

$a^{1 n}$

\section{0}

0
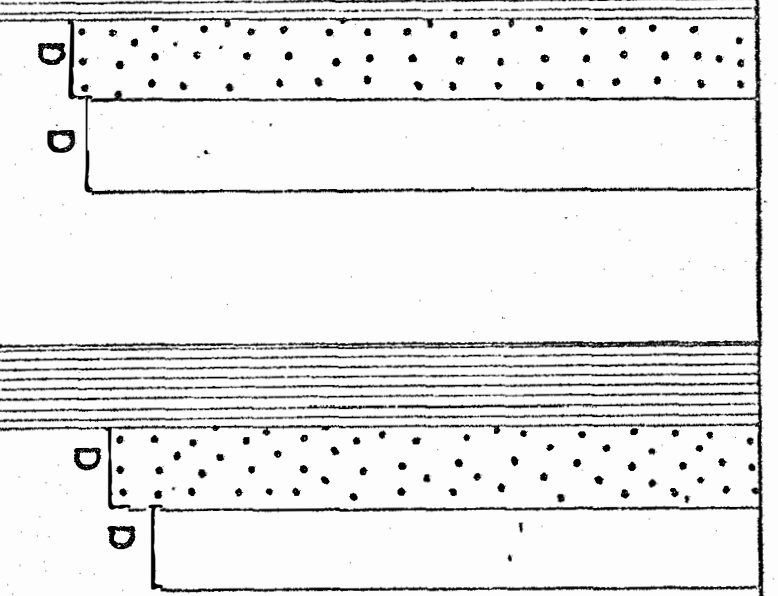

0

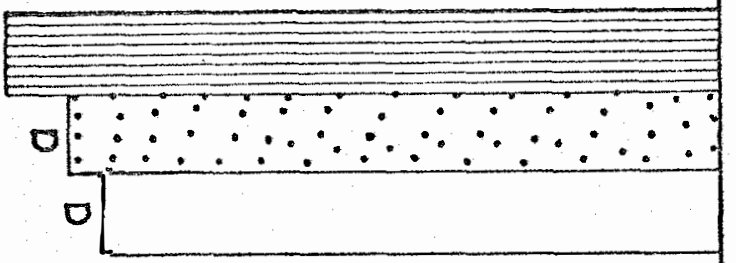

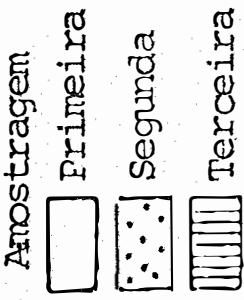

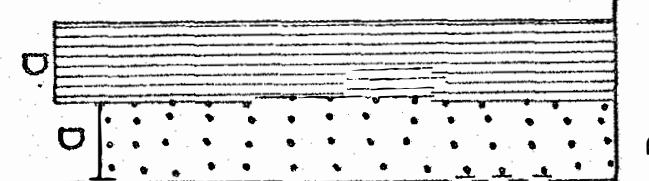

in

0

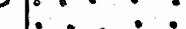

$a^{m}$

$a^{\pi}$

a

$a^{-1}$

0
0
0

20

E

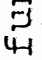

离

छ̇

엉

प्ष

T⿱宀

\&

0

r

f

-

त)

S

F 10

O

त⿵

0) ते

व

0

io

ig

\% 0

I

0 0

U 0

G U

ن

?

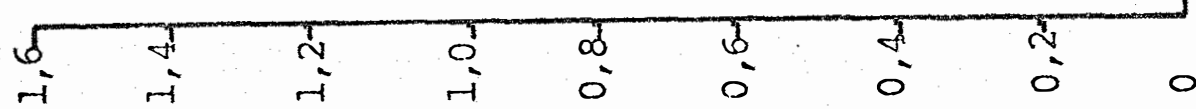

. $\varepsilon^{\text {mo oOt/bau 'otos ou eD }}$ 

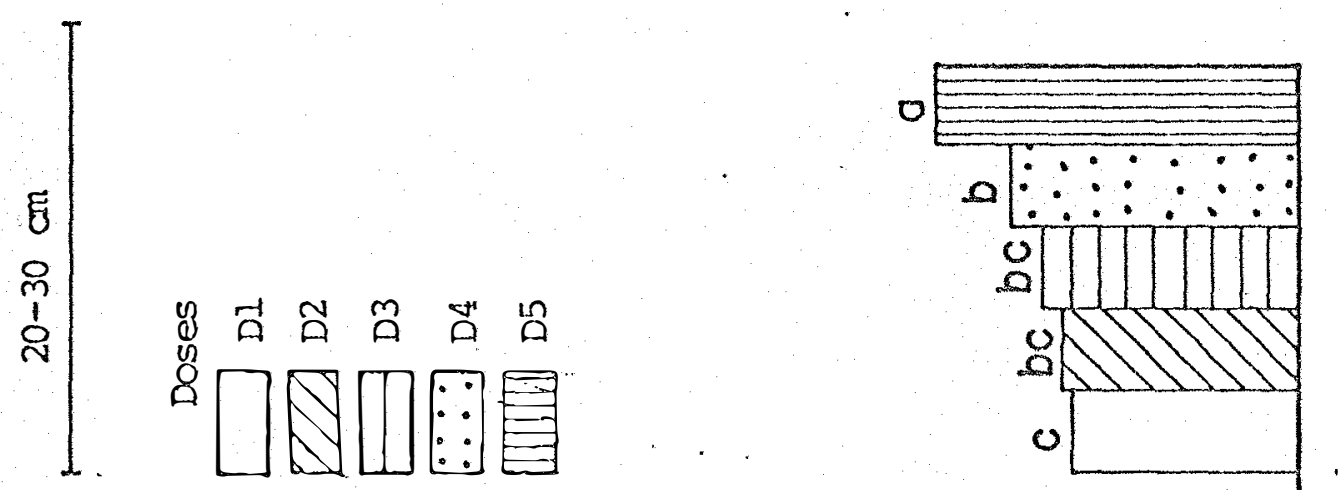

$\xi$
0
$o$
$i$
0
-1

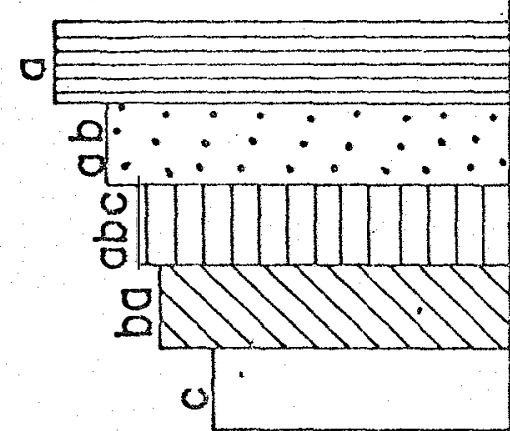

0
0
0
0
0
0
0
0
0
0
5
0
4
0
4
$-r$
$r 0$

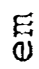

in

\&

0
0
0
10
0
0
0
0
$E$

$\xi$
0
0
1
0
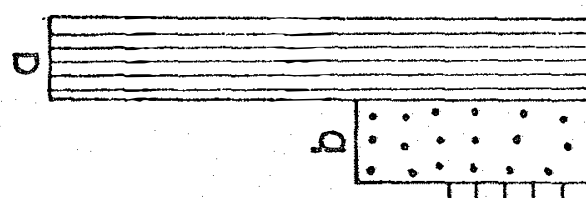

ro

0
0
20
0
0
4
4
5
0
0
4
0
$ن$

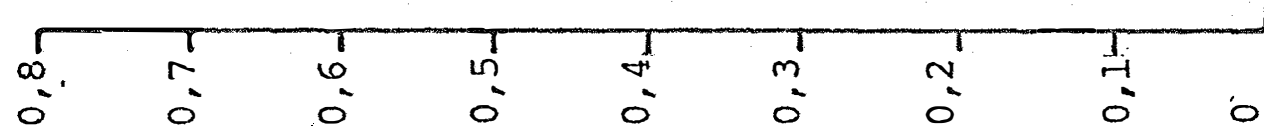

1

$\varepsilon^{\text {upoot/bour 'otos.ou biv }}$ 


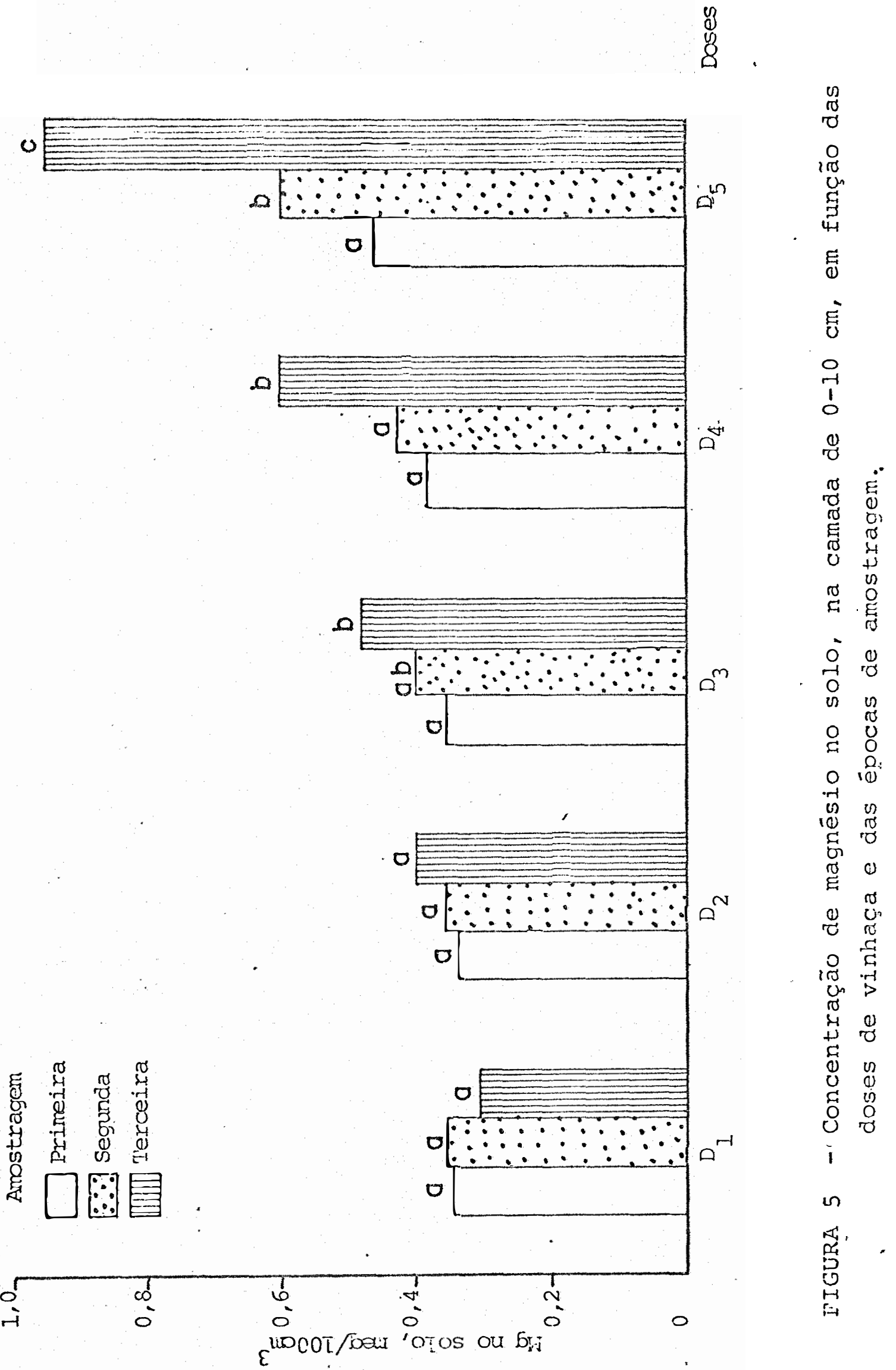


E
0
0
1
in

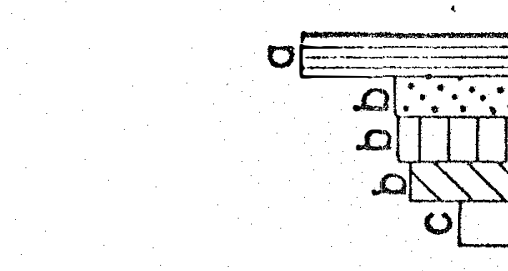

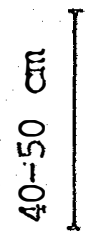

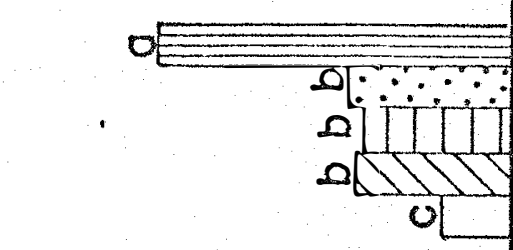

$E$
$\dot{7}$
1
$\dot{m}$

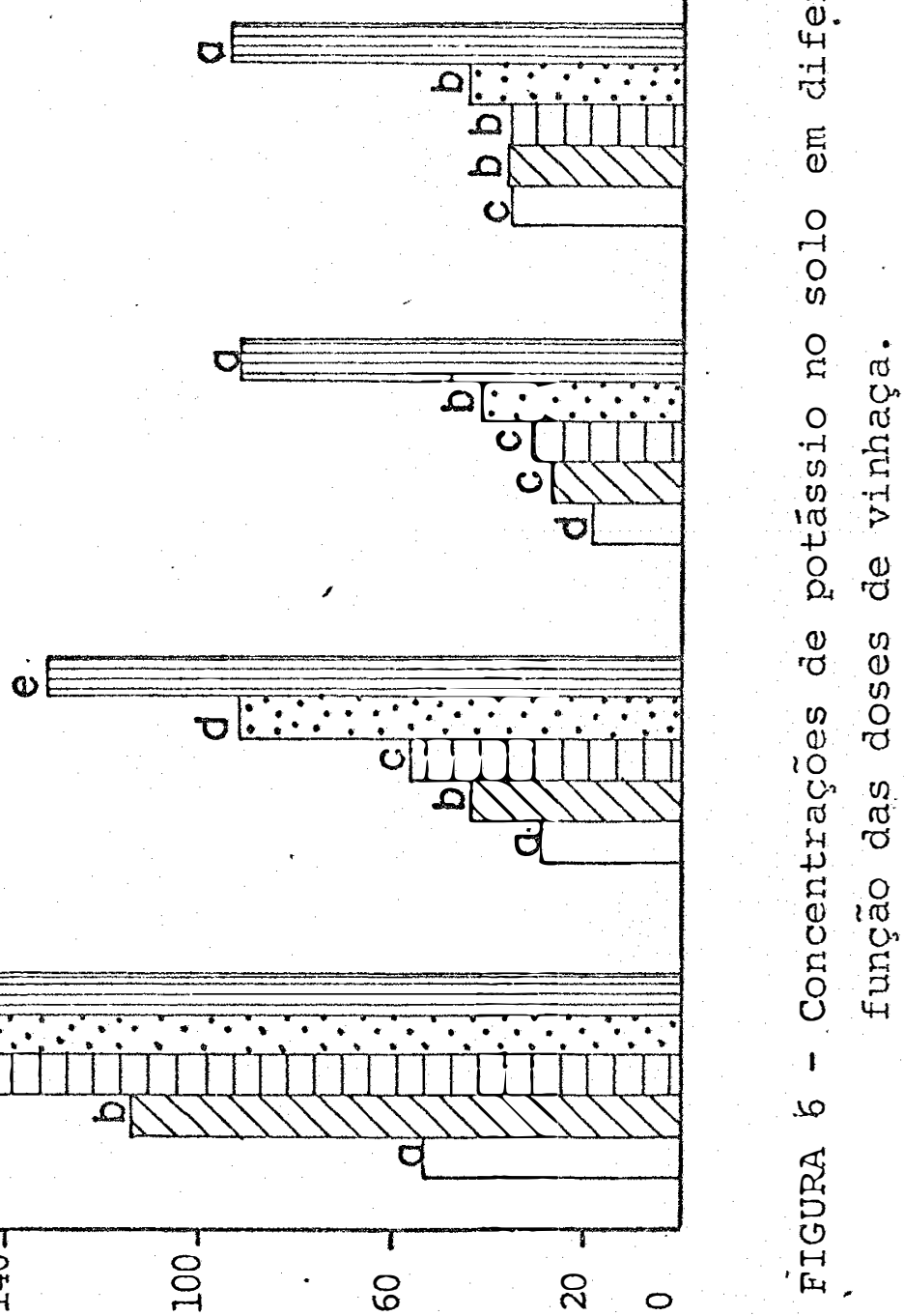

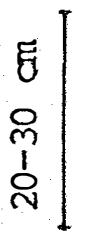

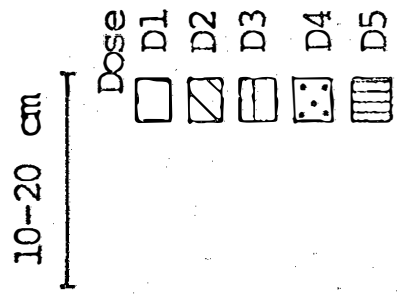
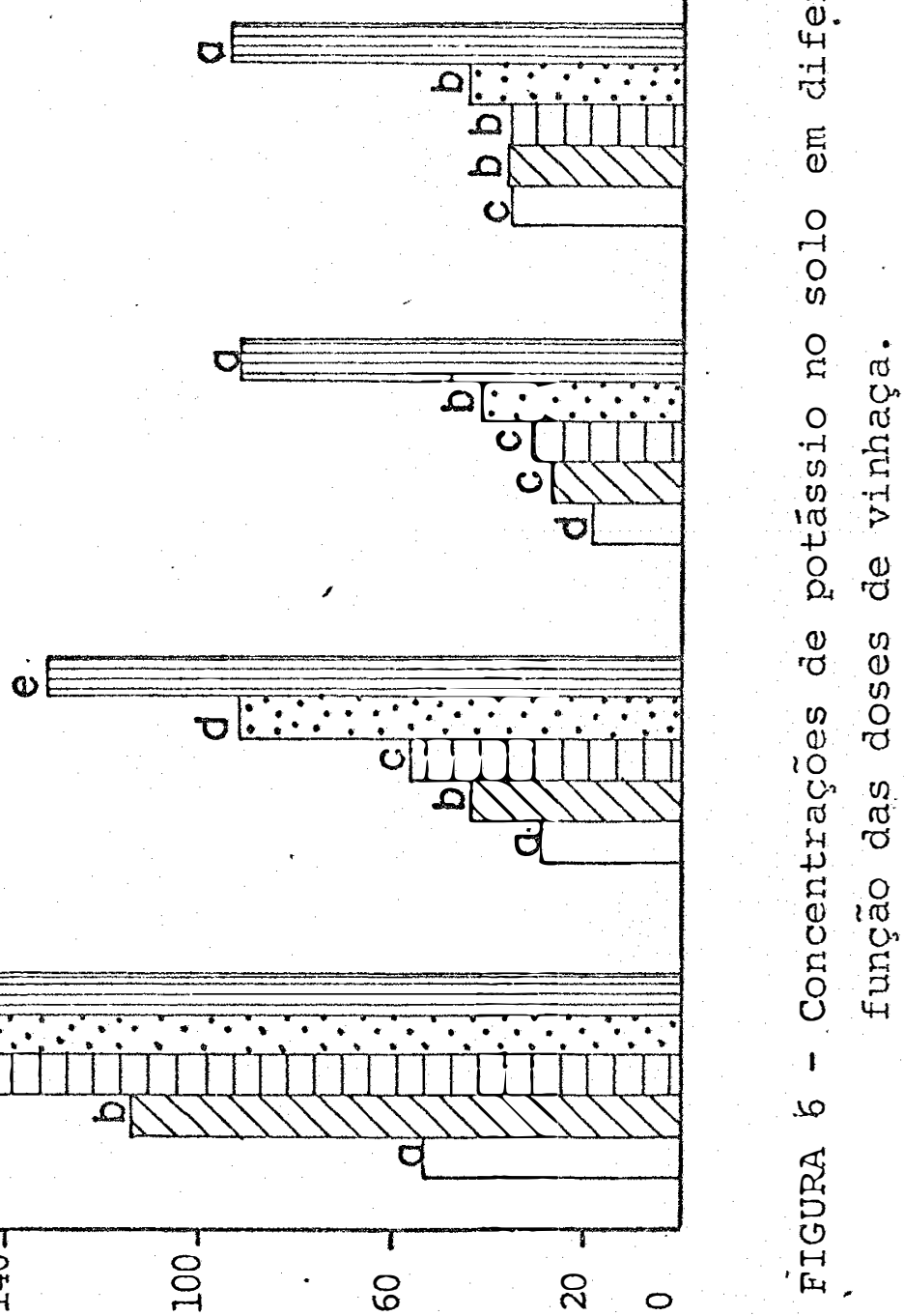

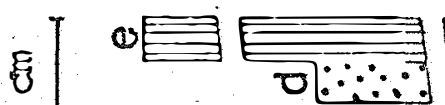

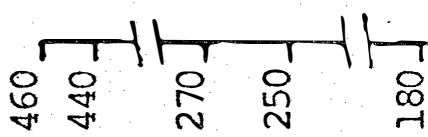

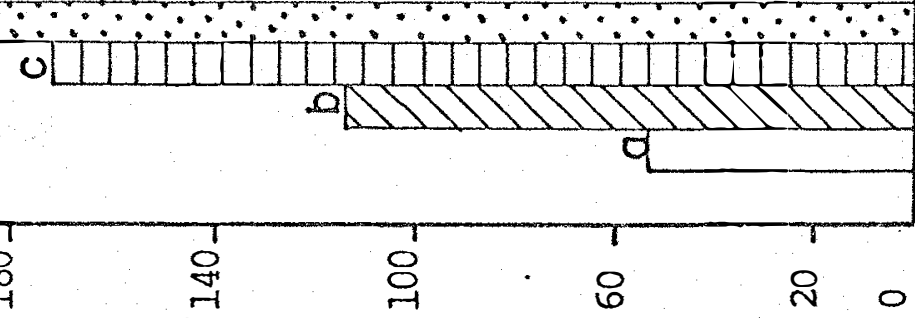

$\varepsilon^{\text {uD/5ur 'otos ou y }}$ 
Os altos teores de potássio verificados princi palmente na: camada de 0-10 cm, atingindo valores de 708 $\mu \mathrm{g} / \mathrm{cm}^{3} \mathrm{com}$ a aplicação de $1200 \mathrm{~m}^{3} / \mathrm{ha}$ de vinhaça na terceira amostragem (Figura 7), pode ser uma das causas do deslocamen to do $\mathrm{Mg}$ até a profundidade de $30 \mathrm{~cm}$ (Figura 4). NUnES et alii (1982) relataram que elevadas concentrações desse cá tion monovalente podem atuàr deslocando para a solução do so 10, parte dos íons Mg adsorvidos, tornando-os suscetíveis à lixiviação.

Ainda deve-se mencionar, que essas elevadas concentrações de $\mathrm{K}$ proporcionadas principálmente pelas doses $\mathrm{D}_{4}$ e $\mathrm{D}_{5}$, contribuiram de maneira considerável no aumento da soma de bases (Figura 8) e na partićipação porcentual desse cátion nos valores de $S\left(K . S^{-l} .100\right)$, como pode ser observado respectivamente nas Figuras 9-10 e 11.

Observando na Figura 11 os dados da saturação em potássio $\left(K \cdot T^{-1} \cdot 100\right)$, chama a atenção o fato da dose de $1200 \mathrm{~m}^{3} / \mathrm{ha}$ de vinhaça proporcionar na camada de 0-10 cm, valores dessa variâvel pröximos a $25 \%$

Resulțados semelhantes foram obtidos por CAMAR GO et alii (1983) e MAZZA (1985) em solos tratados com vinha ça' por um longo período de tempo.

A literatura mostra que o equilíbrio entre 'os nutrientes $\mathrm{K}$, Ca e Mg no solo é importante na nutrição das plantas, verificando-se que um desequilíbrio de concentrações 
$E$
0
1
7
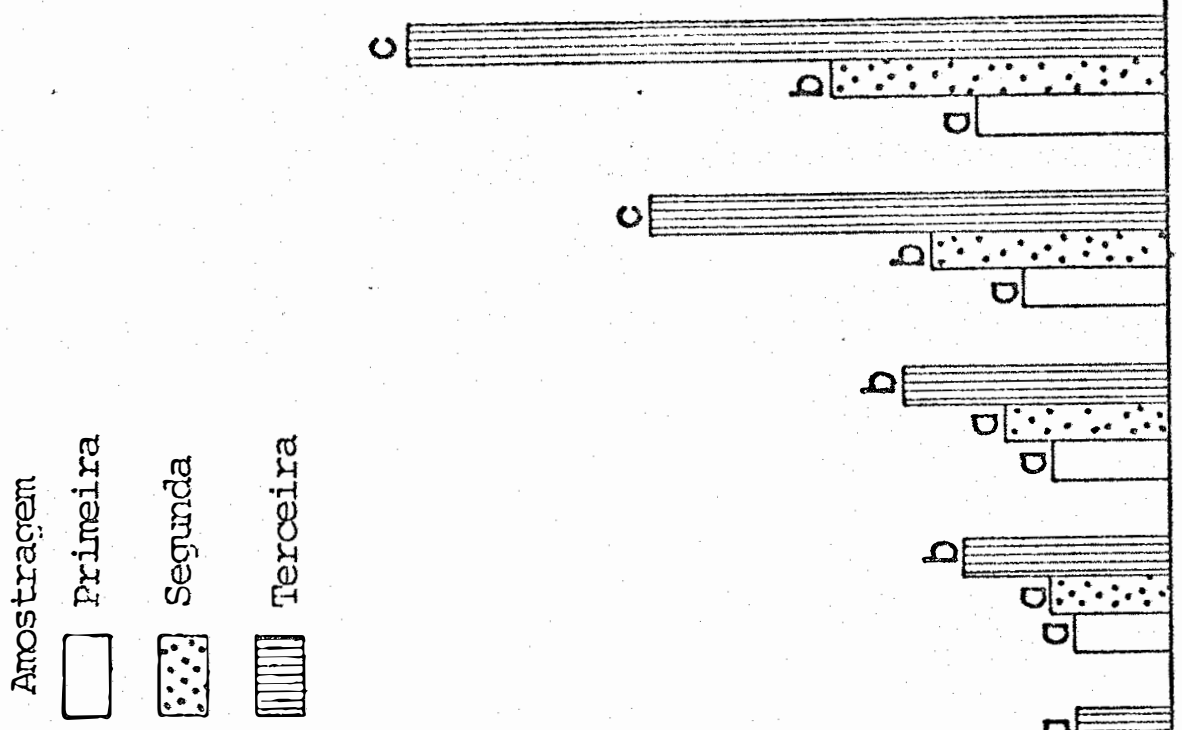

$a^{n}$

0

Un

4

Eี

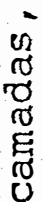

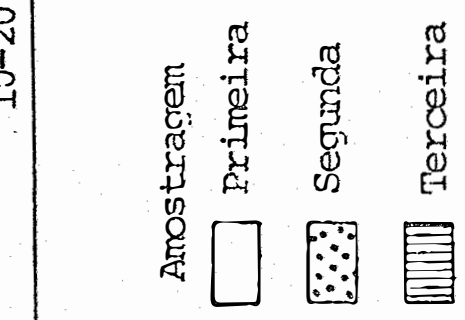
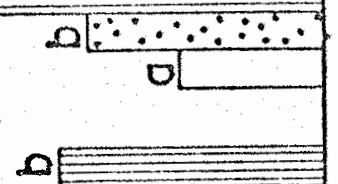

$0^{\nabla}$

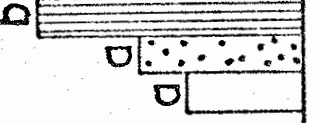

$a^{m}$
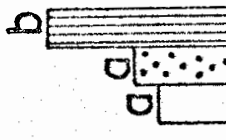

i

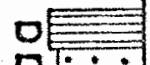

0

$0^{-1}$

0
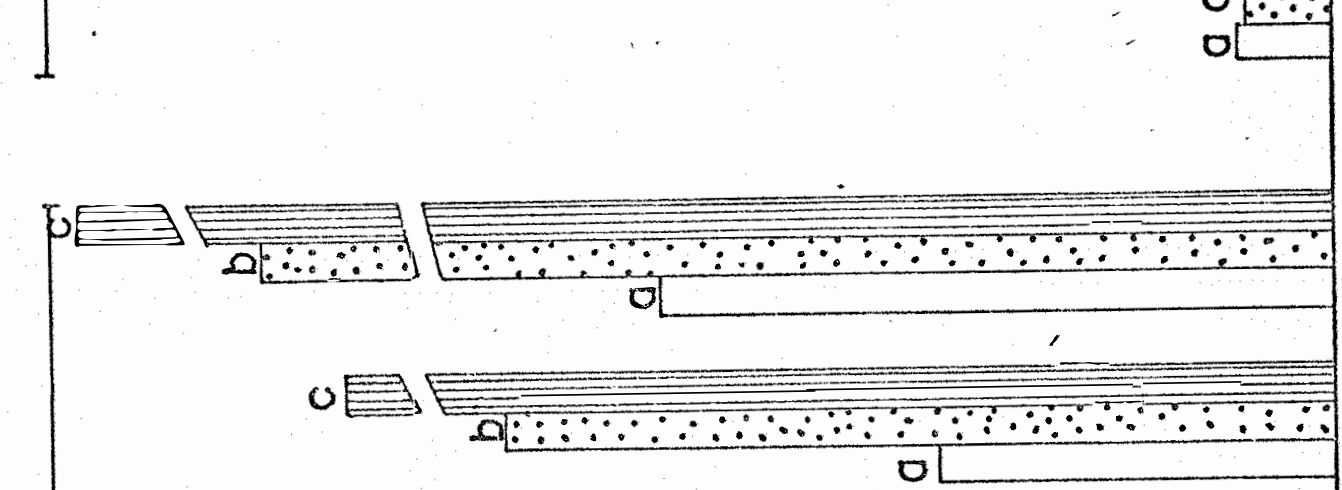

in

Eี

우

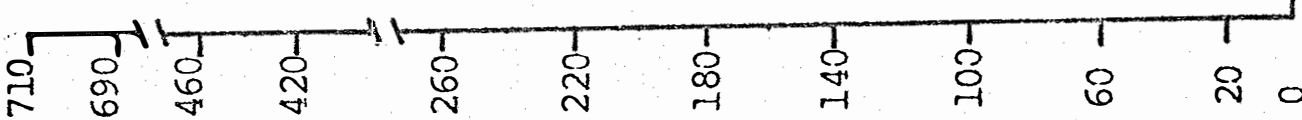

$$
\varepsilon^{\text {us } / \text { jum 'otos ou } x}
$$



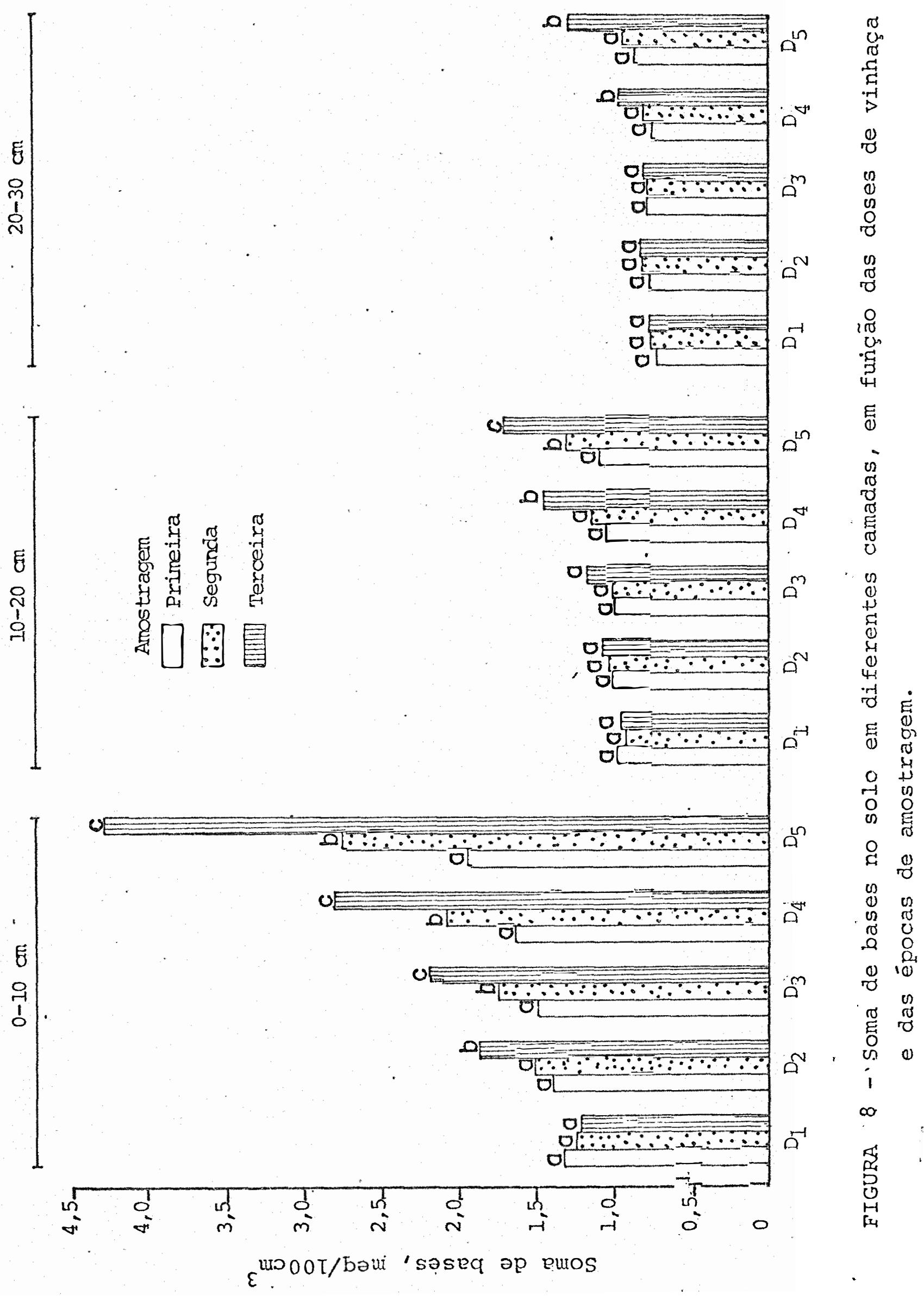

E

으

?

兒口回 
\begin{tabular}{l} 
\\
\\
\\
$\xi$ \\
0 \\
1 \\
0 \\
\hline \\
\end{tabular}

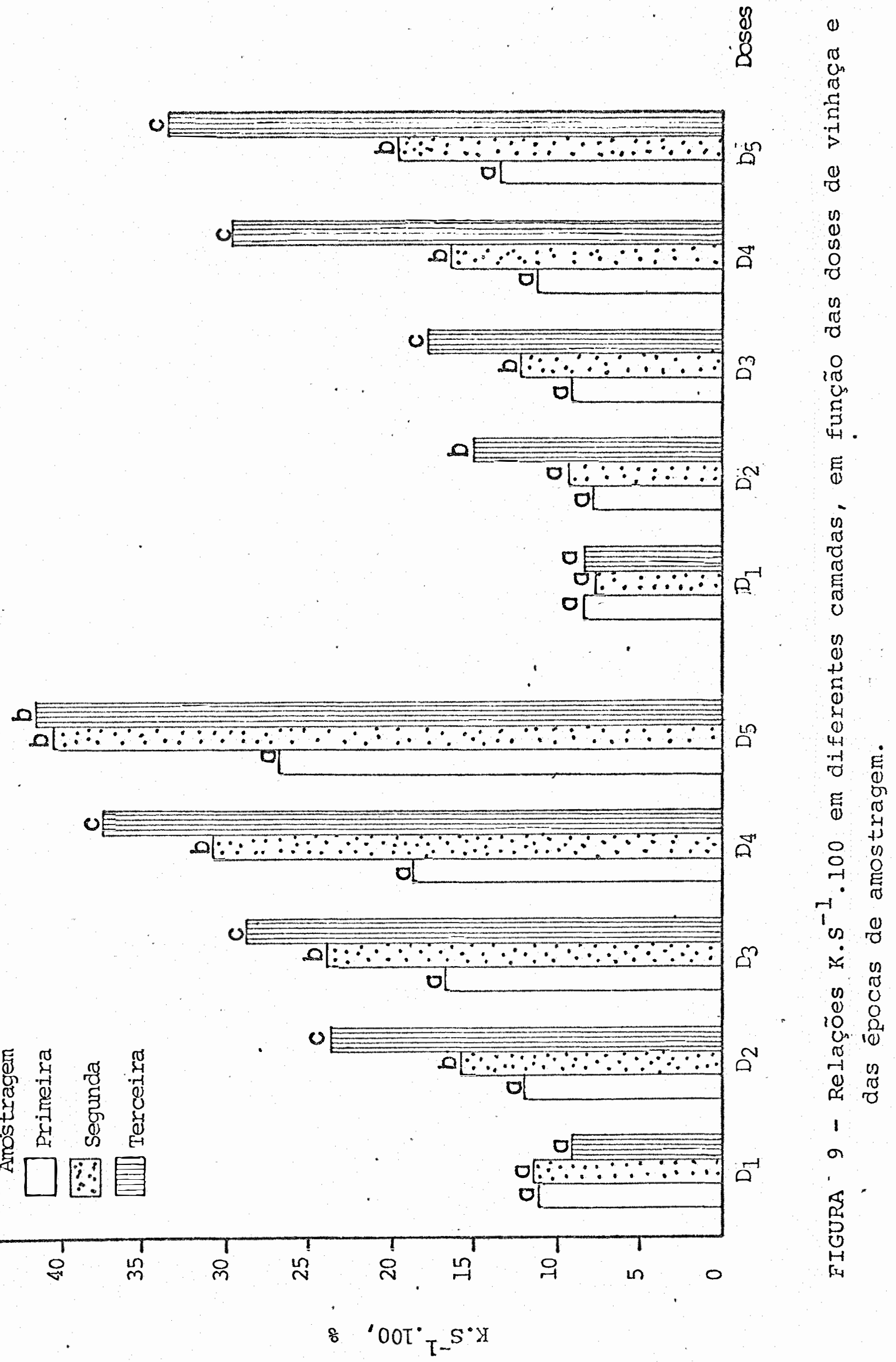




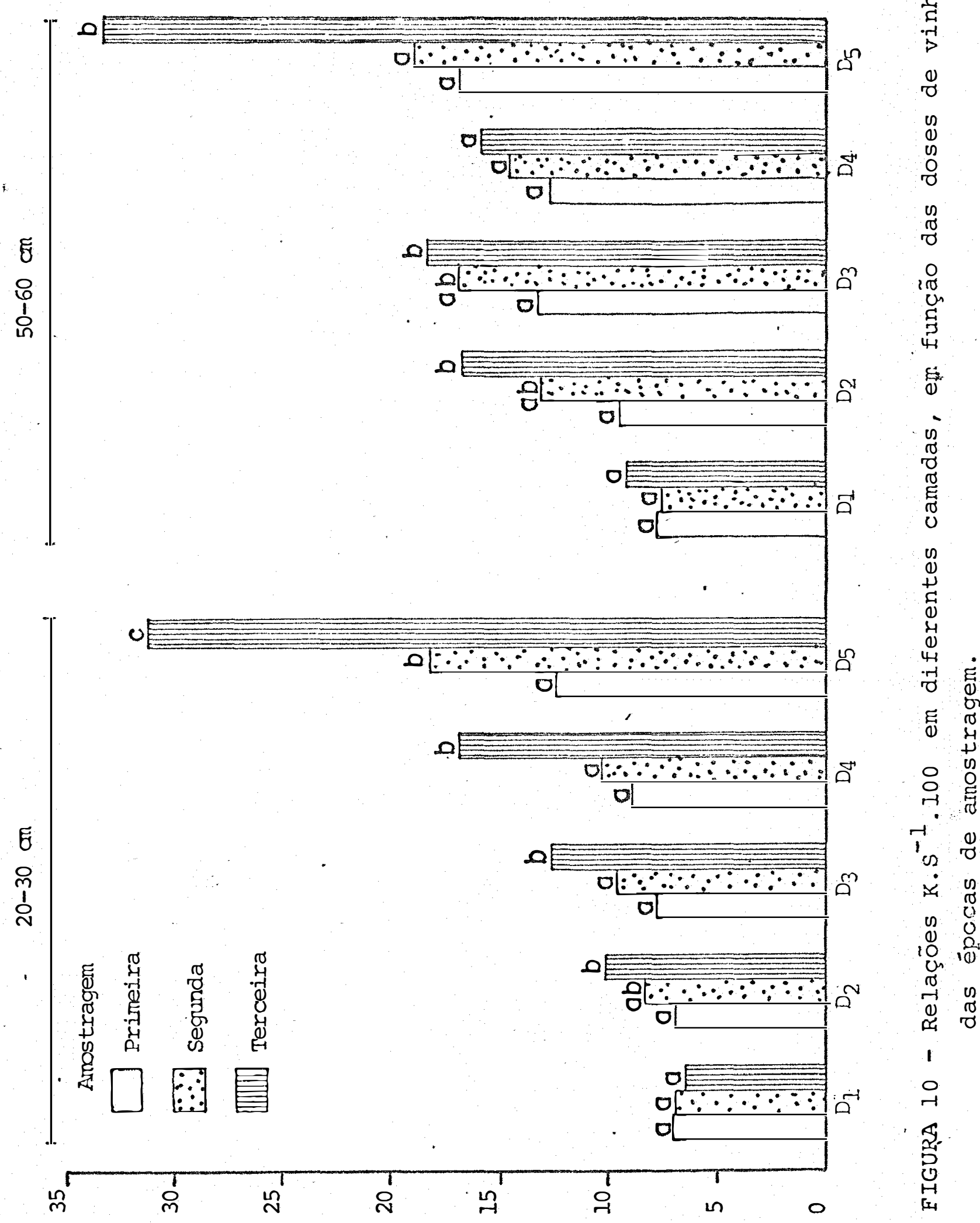

8 'OOT" T-S'Y 

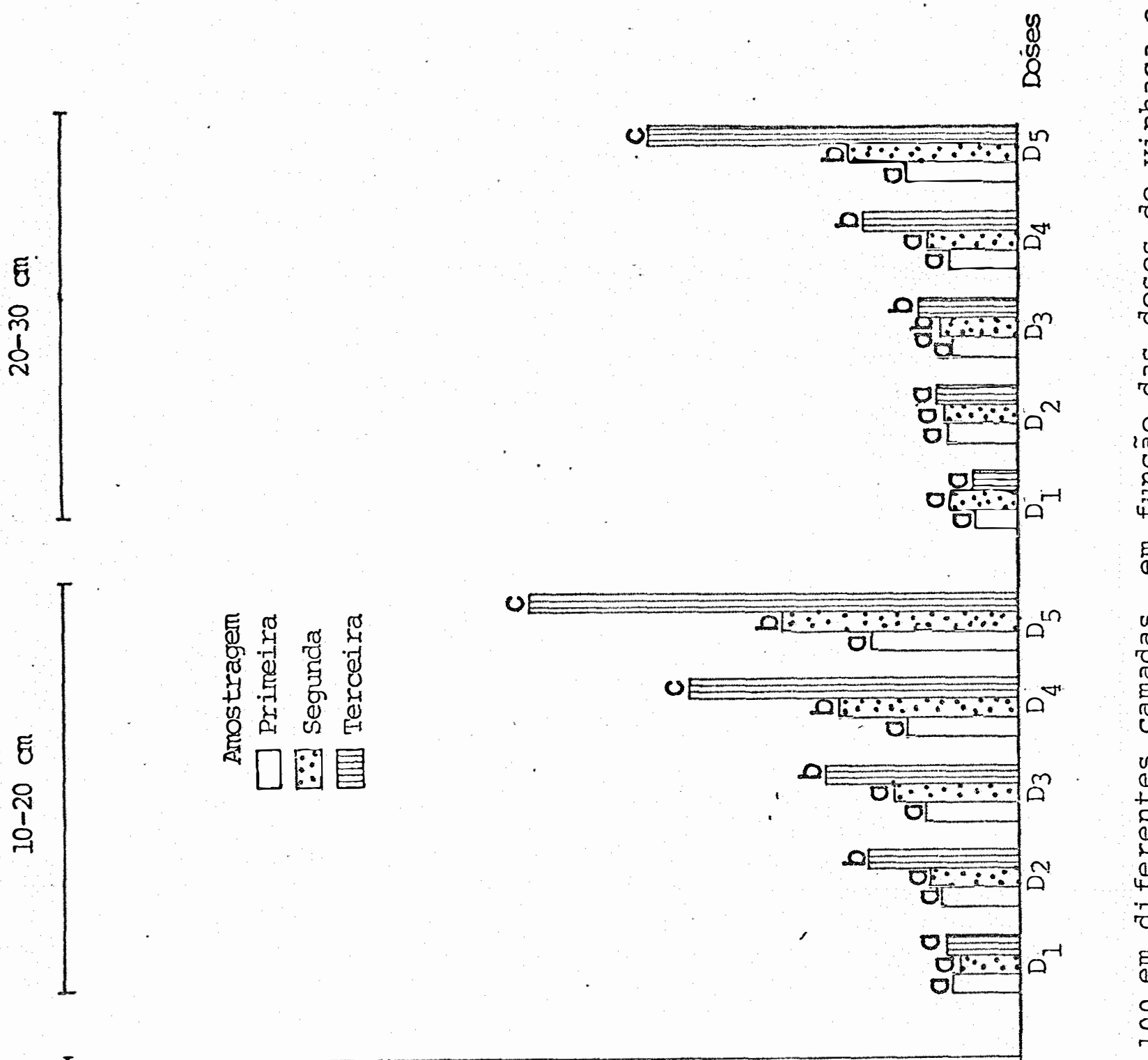

c)

U్ర

c.

व

0

o

㞼

:

U⿱ 4 .

音

0
0
0
0
$E$
0
0
0
0
1
0
0
4
0
41
-1
0
$E$
0
0
0
0
0
0
0

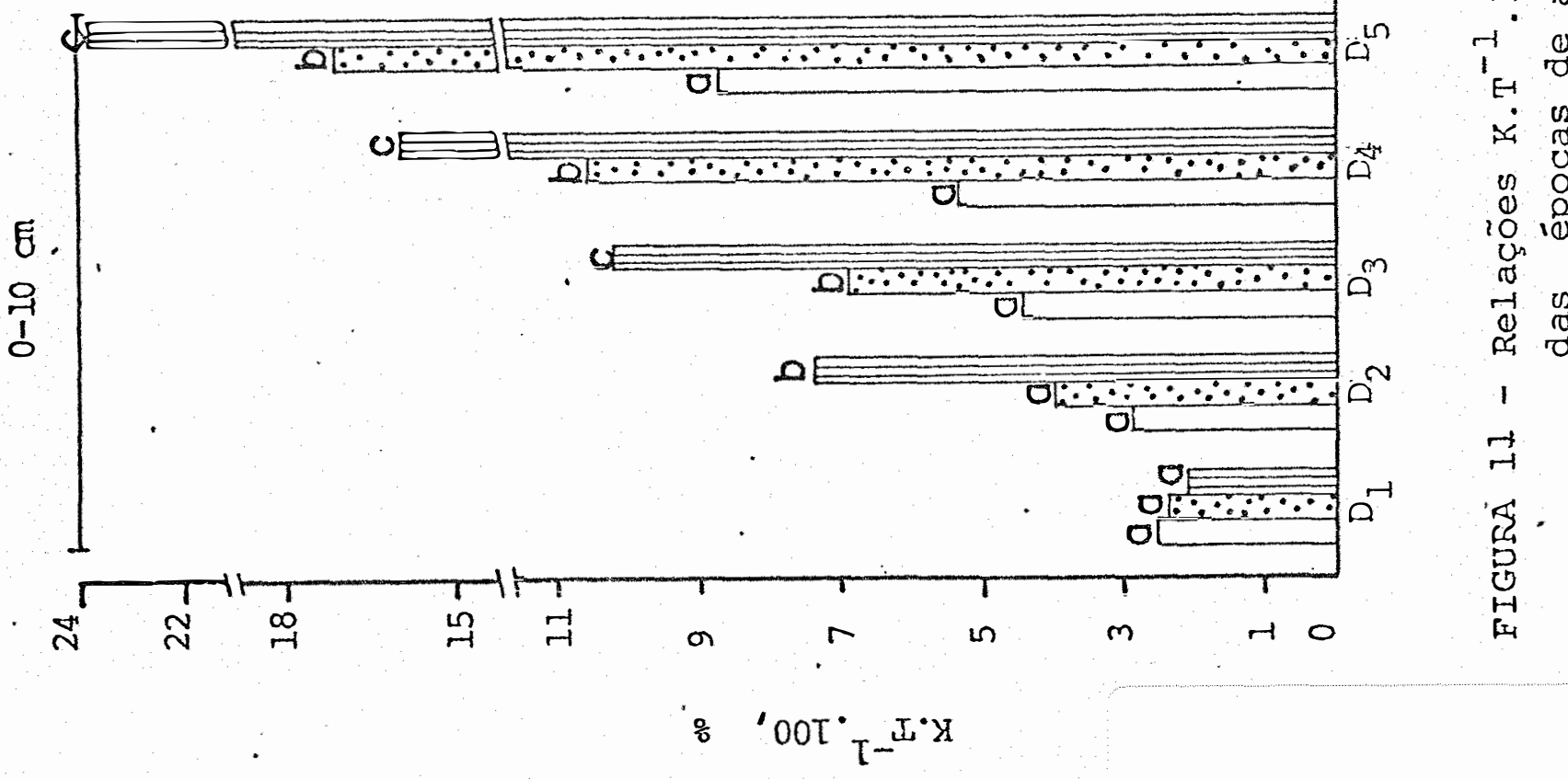


provoca influências recíprocas em termos de disponibilidade no solo,absorção e transporte na planta.

Neste sentido, Bear et alii (1945) citados por MCLEAN (1984) sugeriram pará um solo "ideal" uma saturação de potássio de 5\%. Entretanto, os resultados apresentados na Figura 11 , mostram que as doses de $600^{\circ}$ e $1200 \mathrm{~m}^{3} / \mathrm{ha}$ de vinha ça, proporcionaram até a profundidade de $20 \mathrm{~cm}$, valores acima daquele considerado ideal, podendo dessa maneira, induzir de sequilíbrios nutricionais na cultura a ser instalada nesse so 10.

Ainda com relação ao $K$, verifica-se através das Tabelas 3 a 5 que o comportamento das doses foi diferente den tro de cada condição estudada.

Nota-se na Figura 12, que até a profundidade de $20 \mathrm{~cm}$, as concentrações desse cátion monovalente foram signi ficativamente menores nos tratamentos que receberam as ãguas das chuvas e as doses mais elevadas de vinhaça.

Por outro lado, o fato das doses de vinhaça pro moverem aumentos significativọ nas concentrações de $K$ até a profundidade de $60 \mathrm{~cm}$ (Figura 6 ), parede indicar que a entra da desse efluente no solo, ocorrendo a altos graus de umida de, è a maior responsável pela distribuição do elemento até essa profunaidade, visto que ANDRIOLI (1982) e LOBATO (1984) observaram que o caminhamento desse nutriente somente ocorria quando os valores de umidade $(\theta)$ eram respectivame-te superio res a 0,30 e $0,40 \mathrm{~cm}^{3} \cdot \mathrm{cm}^{-3}$. Nota-se na Tabela 9 , que nas 

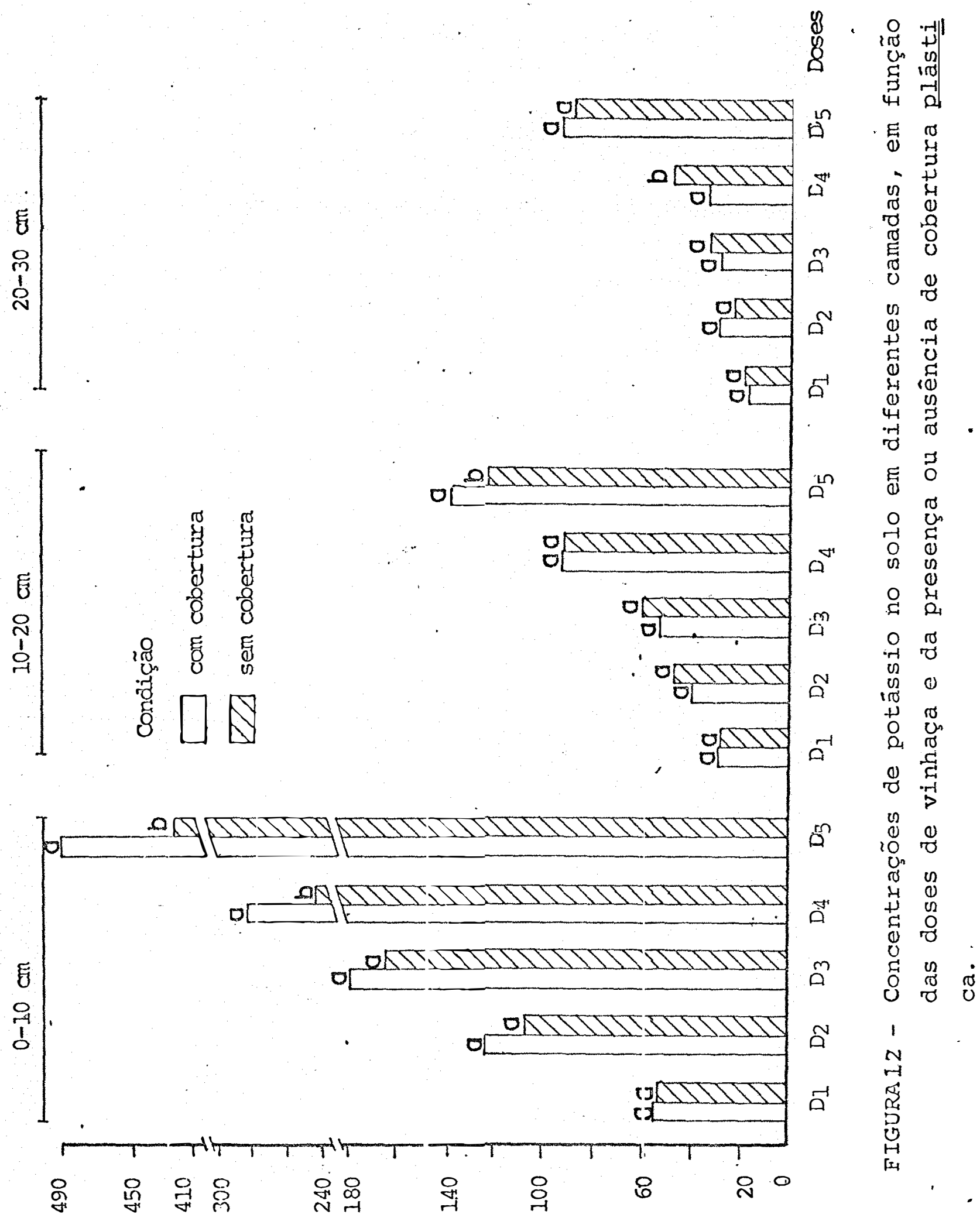

$\varepsilon^{\text {mo/on 'qos ou } y}$ 


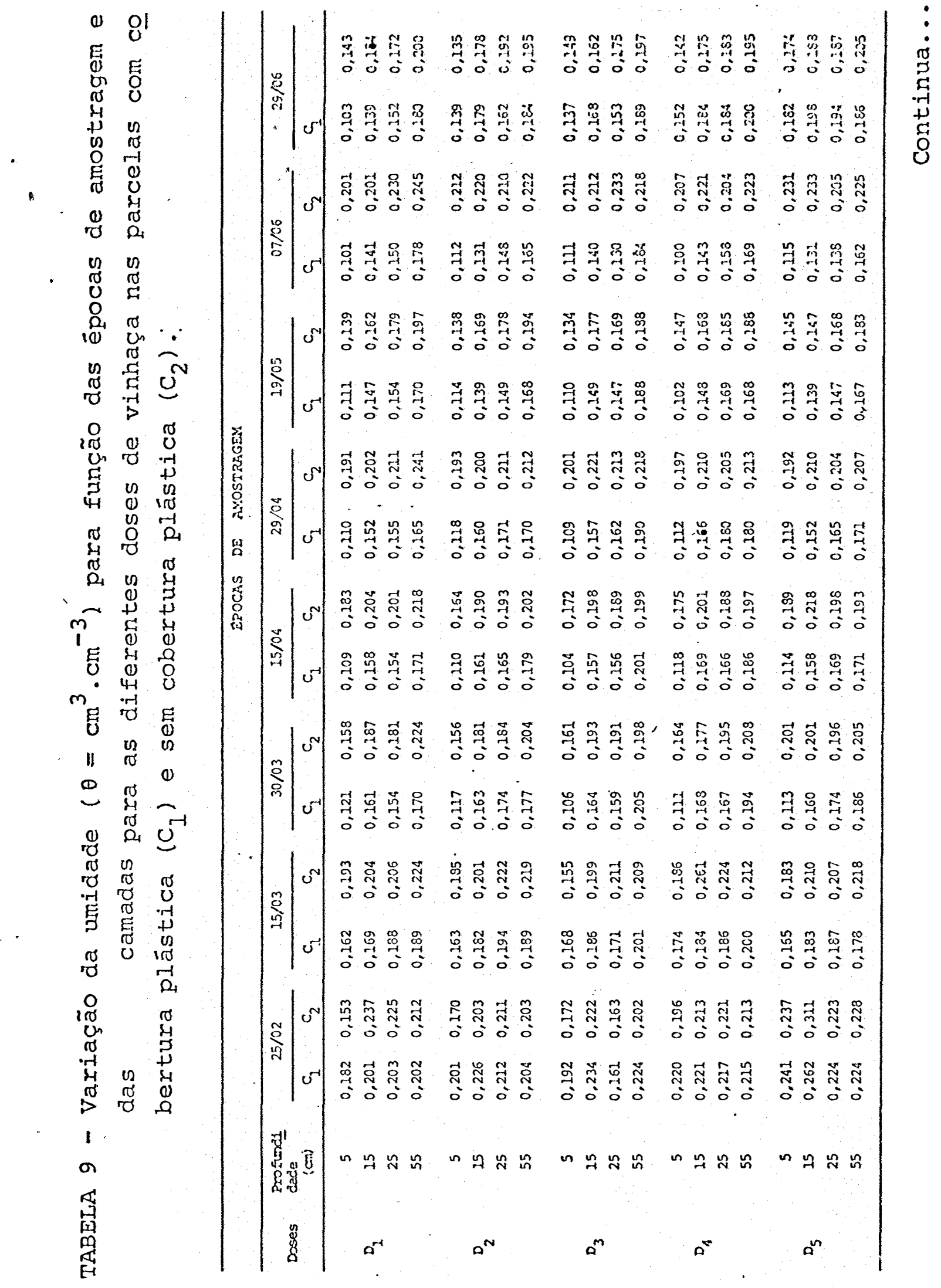




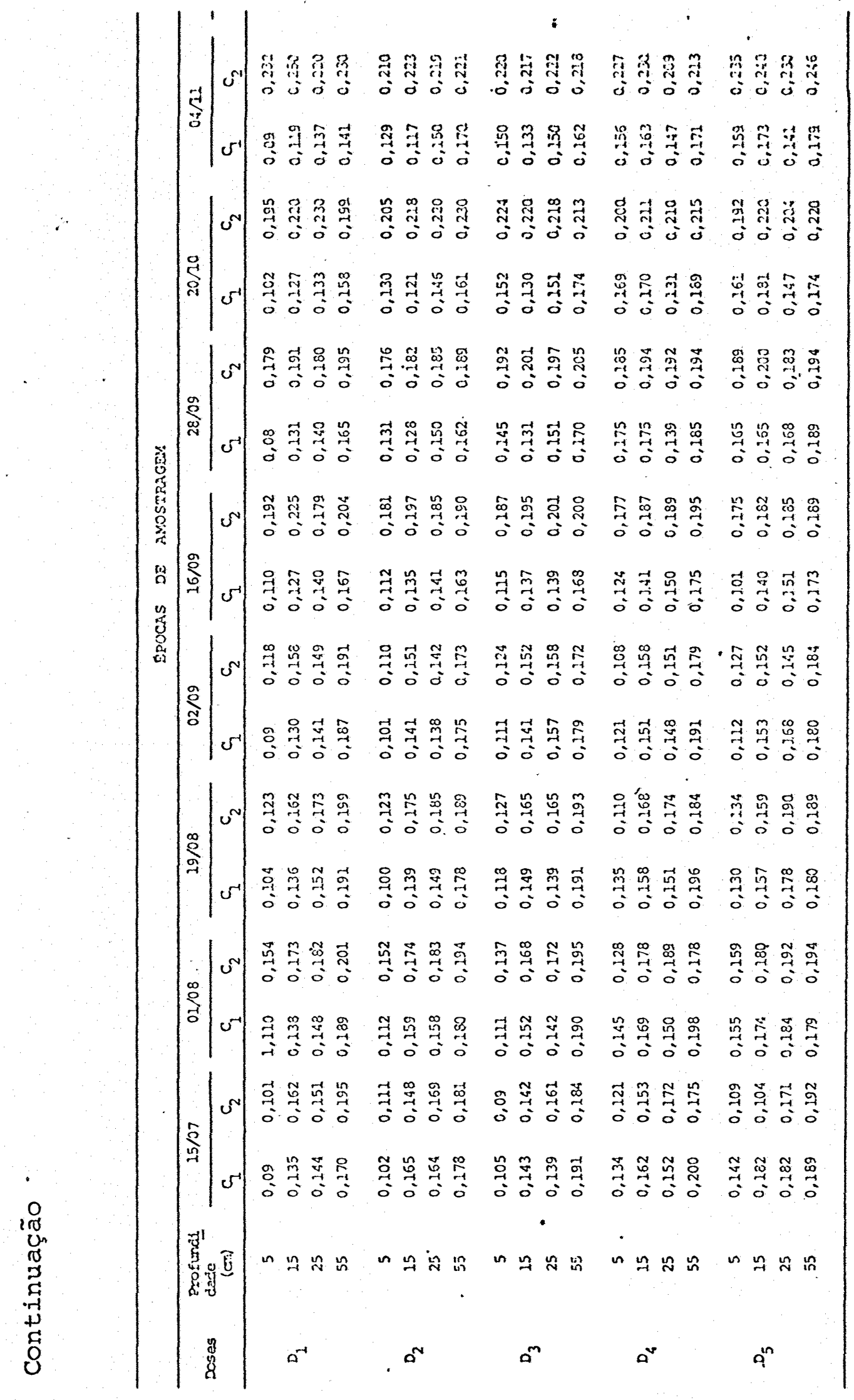


amostragens efetuadas esses valores de $\theta$ não fonam atingidos. Examinando-se a Figura 13, verifica-se que os teores de $\mathrm{K}$ foram inferiores nas parcelas sem cóbertura plás tica, para a terceira amostragem, a qual foi realizada duran " te o período chuvoso (Figura 14). Esse fato indica, que a frente de molhamento formada durante a infiltração da água da chuva, é outro fator importante no movimento descendente des se ion.

Considerações análogas podem ser feitas para as concentrações de Mg em função das condições e épocas de amos tragem (Figura 15).

Neste sentido, Quinsenberry é Phillips

citados por ESPINOZA e REIS (1982) verificaram que as maiores perdas de sais aconteceram durante o período de fluxo rápido de água, durante ou imediatamente após um evento de chuva ou irrigação, atribuindo esse fato à presença de macroporos e fraturas, não permitindo assim que a água passe atravēs de uma fração significativa dé massa do solo.

4.4. Capacidade de troca catiônica e saturação em bases

Verifica-se através da Figura 16., que a dose mais elevada de vinhaça aumentou significativamente a capacidade de troca catiônica ( $T$ ). Os incrementos nessa variāvel foram apenas observados ná terceira amostragem (Figura 17), indican do o efeito cumulativo das doses de vinhaça. 


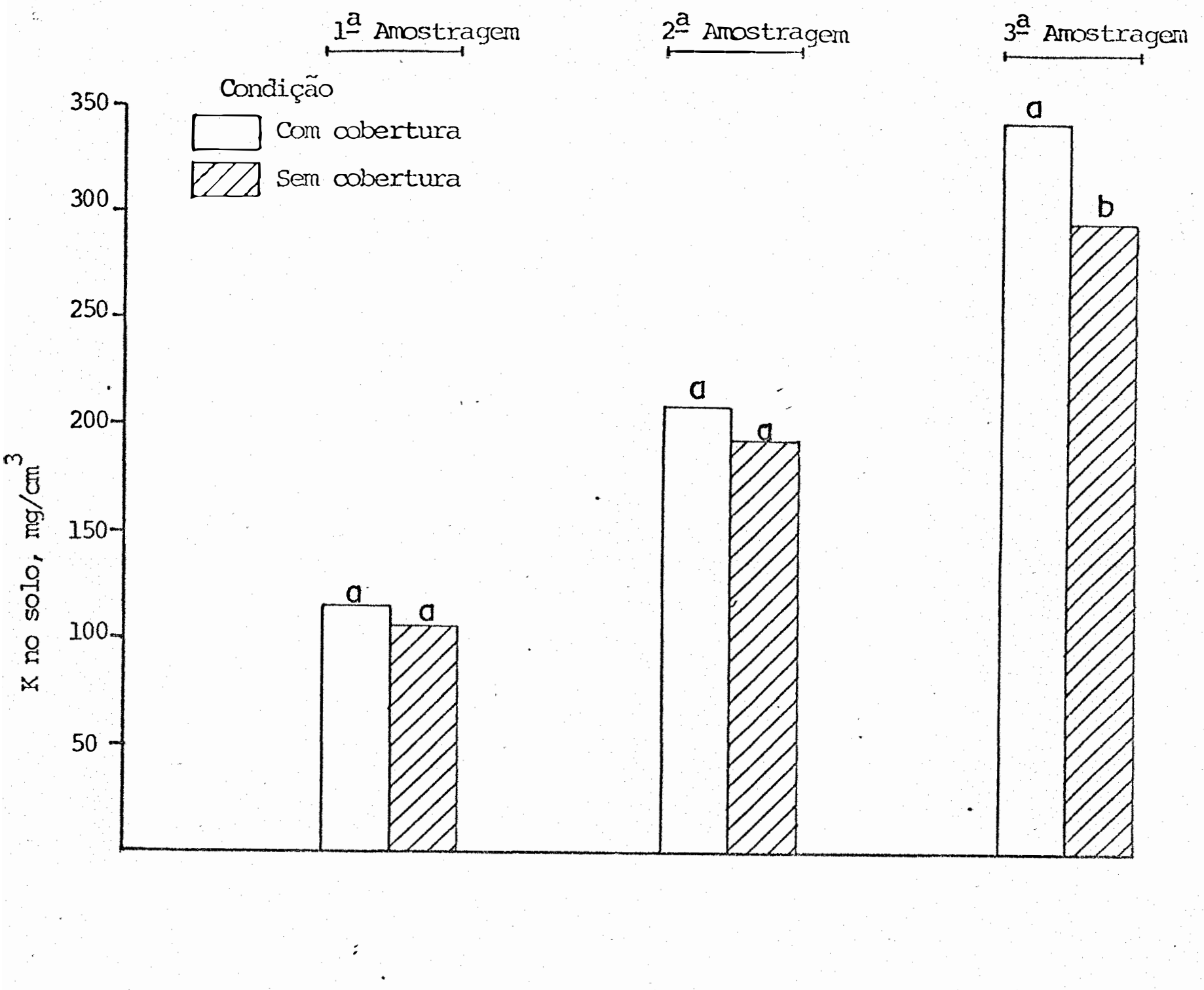

FIGURA 13 - Concentrações de potássio no solo, na camada de $0-10 \mathrm{~cm}$, em função da presença ou ausência de cobertura plástica e das épocas de amostragens. 


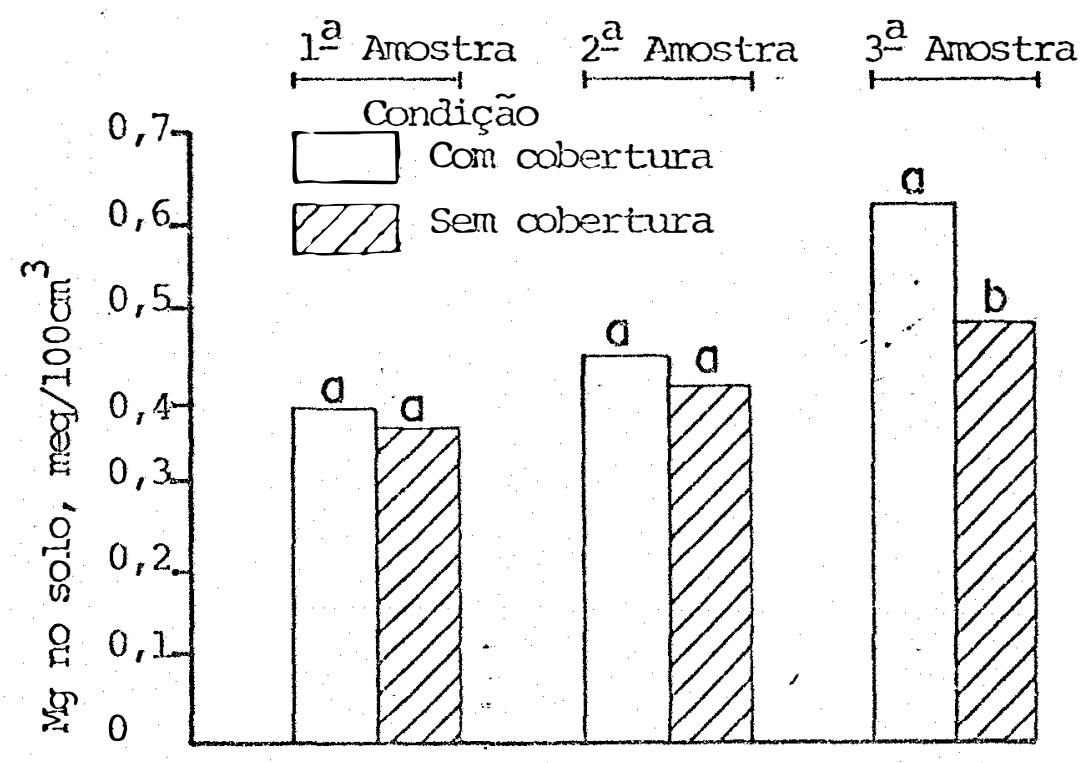

FIGURA 15 - Concentrações de magnésio no solo, na camada de 0-10 cm, em função da presença ou ausência de cobertura plästica $e$ das épocas de amostragem, 


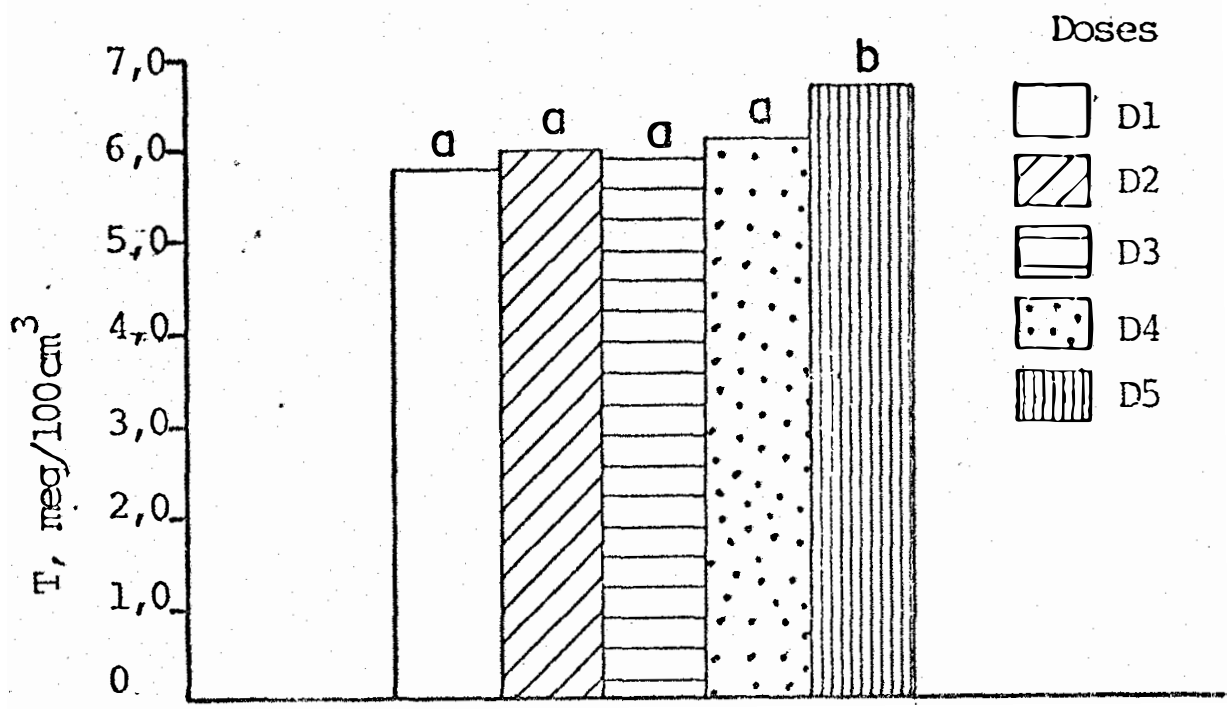

FIGURA 16 - Capacidade de troca de cátions no solo na camada de $0-10 \mathrm{~cm}$.

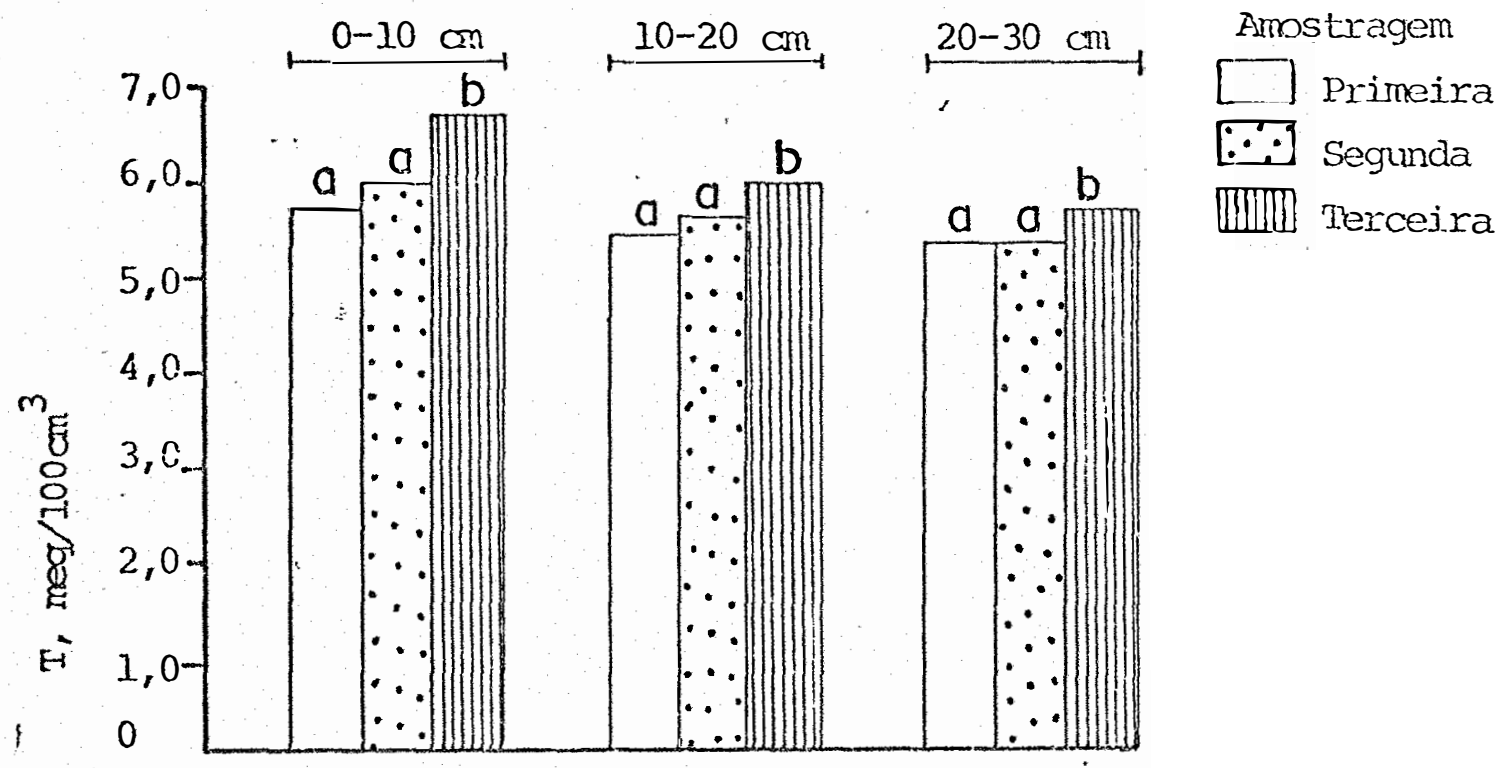

FIGURA 17 - Capacidade de troca de câtions no solo em diferentes camadas, em função das épocas de amostragem. 
Entretanto, considerando-se que os teores de ma téria orgânica não aumentaram significativamenté com a aplica ção das doses crescentes de vinhaça e a metodologia utilizada na determinação da acidez potencial $(H+A l)$, os incrementos observados nos valores de $\mathrm{T}$ deve-se a presença de sais em sô lução e não a um aumento de cargas negativas do solo.

Por outro lado, a elevação nos teores dé potás sio fizeram com que a saturação em bases (V\%) fosse alterada significativamente (Figuras 18 a 20).

Deve-se ressaltar entretanto, que na camada de 0-10 cm existe também a contribuição do Ca e Mg elevando os valores de V.

A discussão para o $K$ no İtem 4.3. é válida tam bém para a saturação em bases do solo, em vista da relação o.i reta observada entre essás variâveis.

Incrementos nos valores da capacidađe de troca catiônica e saturação em bases do solo, também foram observa dos por VALSECHI e GOMES (1954), BRIEGER (1977), AGUJARO (1979), CAMARGO et alii (1983), COLETI et alii (1983), SENGIK (1983) e MAZZA (1985).

4.5. Caracterização do meio poroso

O meio poroso do solo avaliado atravēs da densi dade global, porosidade total calculada, e macro e microporosidade não foi influenciado pelas doses de vinhaça litiliza 

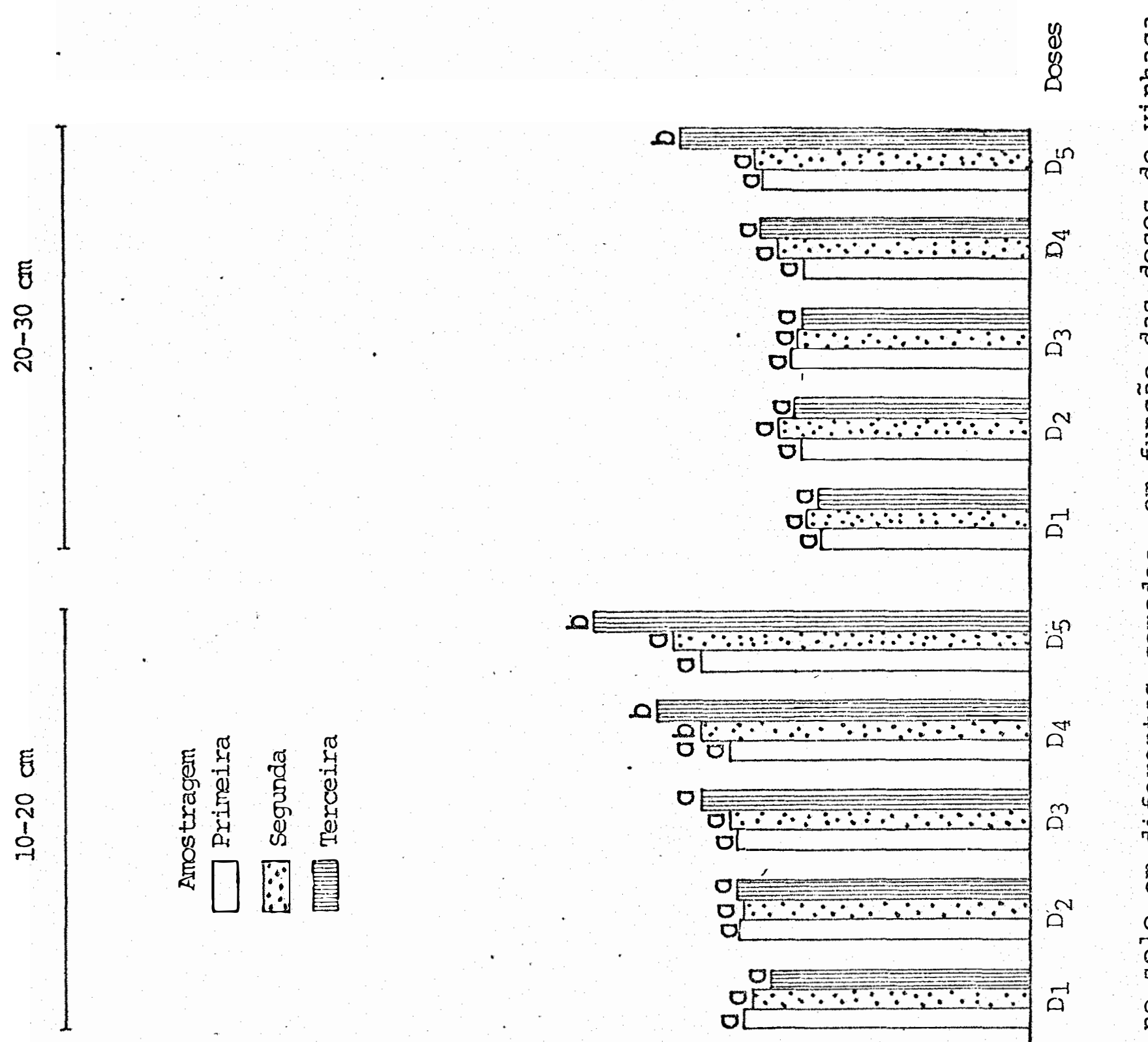
$a^{\ln } \frac{0}{0}$ $\therefore$

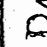

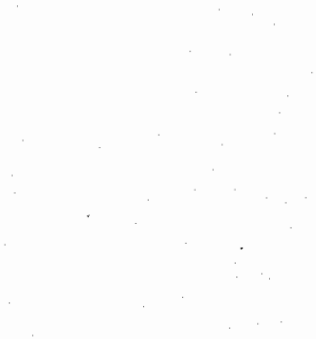

¿্

\begin{tabular}{l}
0 \\
0 \\
4 \\
\hline \\
0 \\
4 \\
0 \\
4 \\
-1 \\
0
\end{tabular}
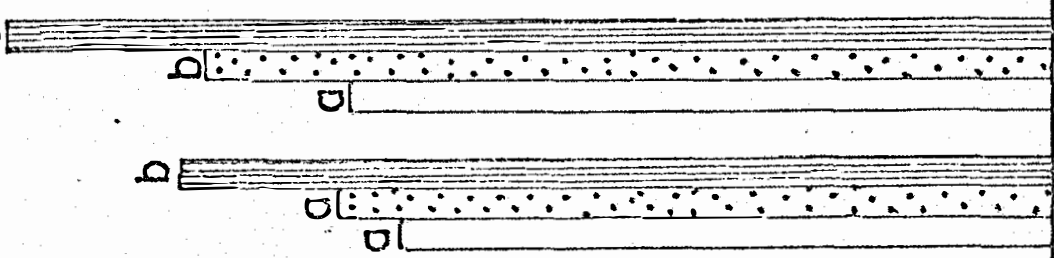
020

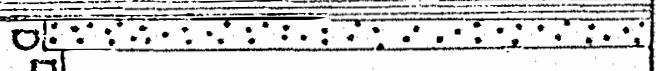




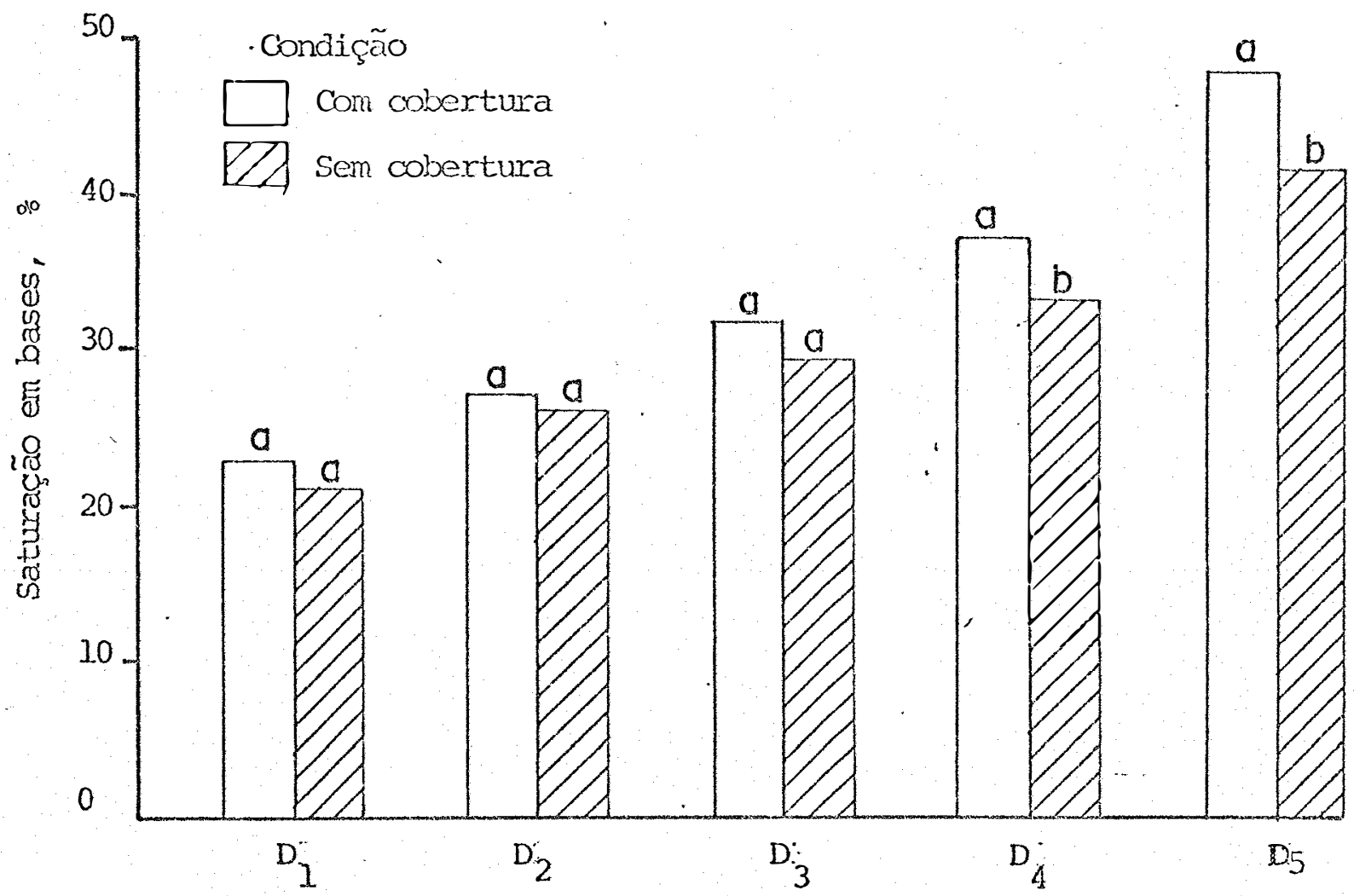

Doses

FIGURA 19. - Saturação de bases no solo, na camada de 0-10 cm; em função das doses de vinhaça e da presença ou ausência de cobertura plástica. 


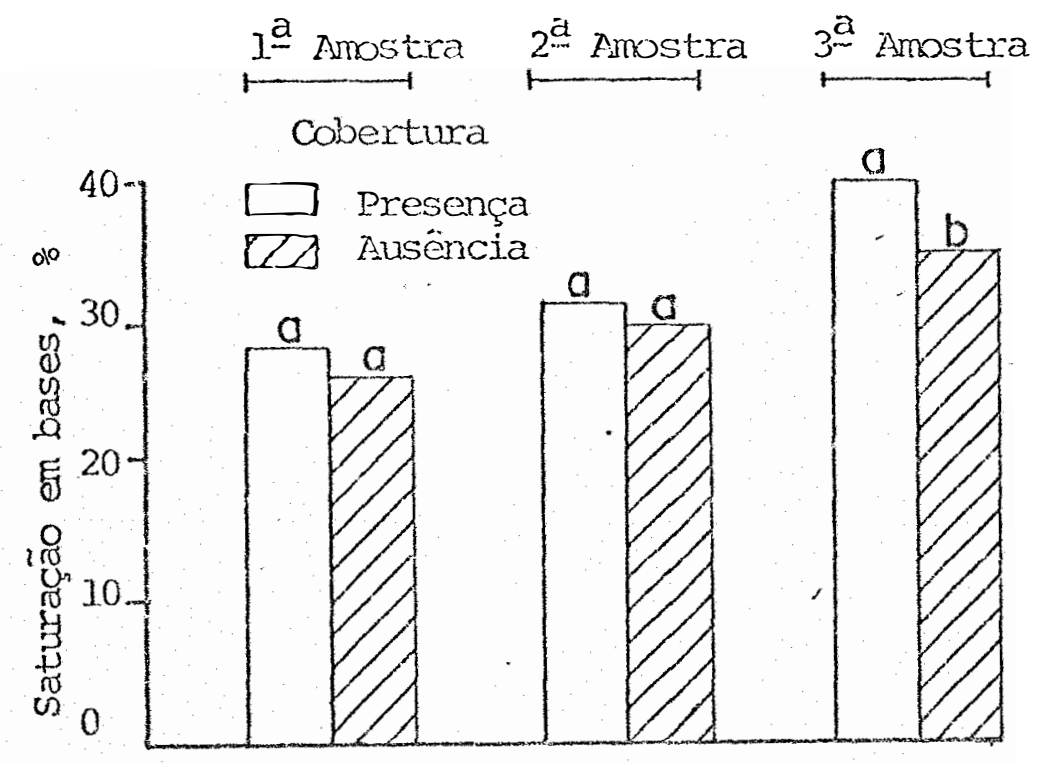

FIGURA 20 - Saturação de bases no solo, na camada de 0-10 cm, em função das épocas de amostrágem e da presença ou ausência de cobertura plástica. 
das em nenhuma profundidade estudadä como pode ser observado nas tabelas 10. Estes resultados são concordantés com os obti dos por REZENDE (1979) e contrariam os de CESAR e MANFRINATO (1954) e RANZINI (1956). Uma das explicações para tal fato po de ser atribuido a não variação nos teores de matéria orgâni ca do solo em função da aplicação das doses crescentes de vi nhaça (Tabelas 3 a 5). Pox outxo lado de acordo com climargo et alii (1983), os microrganismos quando metabolizam açüca xes de cadeia pequena, presentes em grande quantidade na vi nhaça, excretam uma mucilagem que tem efeito marcante na aglu tinação das partículas do solo. Fato este confirmado por es tes autores. Entretanto apesar de constatarem uma melhor es truturação nas glebas que receberam vinhaça, observaram que a porosidade e densidade global do solo apreşentaram uma redução e um aumento respectivamente nos seus valores, o que atribuiram a trafego intensos.

As condições de solo sem végetação e sem culti vo pode contribuir para uma alteração no sistema poroso REZEN DE (1979). Assim como no presente estudo estas condições fo ram mantidas, os efeitos benéficos introduzidos, durante a decomposição da matéria orgânica da vinhaça, (CAMARGo et alii. 1985), possivelmente pode ter sido neutralizadas por aqueles outros efeitos.

Desta maneira, questiona-se a recuperação de so Ios depauperados fisicamente, através da utilização de doses racionais de vinhaça. 
4.6. Argila natural e grau de floculação

Apesar da vinhaça ter promovido incrementos nos teores do potāssio no solo e na sua saturação do complexo sor tivo e deste apresentar características dispersantes (CAMARGO et alii, 1983) o estado de flọculaçăo das argilas do solo não foi afetado pelas doses de vinhaça utilizadas, em nenhuma pro fundidade estudada conforme se verifica na Tabela 10. Resulta dos semelhantes foram obtidos por REZENDE (1979) e . SENGIK (1983).

O efeito do potássio como agente dispersante po de ter sido neutralizado, principalmente na camada superfi. cial do solo, pelos efeitos floculantes do cálcio e do magné sio (BAVER et alii, 1972 e RUSSELT, 1973), que aumentaram sig nificativamente naquela camąa. Deve-se salientax tambëm que a interação de outros fatores tais como pH, teor de matéria orgânica (camargo, et aliì, 1983), concentração de cátions, textura, natureza da argila do solo (RIBEIRO et alii, 1983, RIBEIRO e SENGIK, 1.983) afetam consideravelmente o estado de floculação e dispersão da argila.

Nas parcelas em que foram empregados os trata mentos $\mathrm{C}_{2}$ e $\mathrm{C}_{2}$, embora apresentando teores de água diferen tes (Tabela 9), não apresentaram diferenças nos valores de ar gila natural e consequentemente nos de grau de floculação tą bela 1.0. Isto parece indicar mais uma vez que o comportamen 
to do estado de floculação ou dispersão da argila é mais de pendente da interação conjunta de fatores, do que a açao de fatores isolados.

\subsection{Condutividade elétrica}

Os resultados referentes a condutividade eletri ca estão contidos nas Tabelas $3,4,5$ e 8.

A aplicação das doses crescentes da vinhaça ele vou significativamente os valores de condutividade elétrica do solo, até a profundidade de $30 \mathrm{~cm}$, como pode ser observado na Figura 2l. Verificamse ainda nesta que os aumentos foram prporcionais as doses do resĩduo utilizadas, diminuindo a am amplitude dos aumentos em profundidade. 'O maior incremento nos valores desta variável foi averiguado para, o tratamento $D_{5}$ $\mathrm{C}_{2} \mathrm{E}_{3}$ que atingiu 1,672 mmhos/cm na profundidade de 0-10 $\mathrm{cm}$ (Tabela 3) significando uma elevação de 7,6 vezes em relą̧ão ao tratarnento $D_{1} C_{1} E_{3}$.

Estudos realizados por RANZANI (1956), REZENDE (1974), ROSSIELLO et alii (1981). SANTOS et alii (1981) e MAZ ZA (1985) também constataram aumentos nos valores de conduti vidade elêtrica em função da aplicação de doses crescentes de vinhaça no solo.

As equações de regressões $\mathrm{y}=0,1522 \mathrm{x}+0,0017$ 

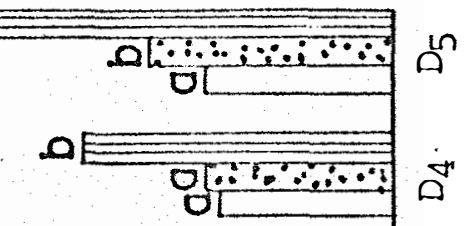

10

孚
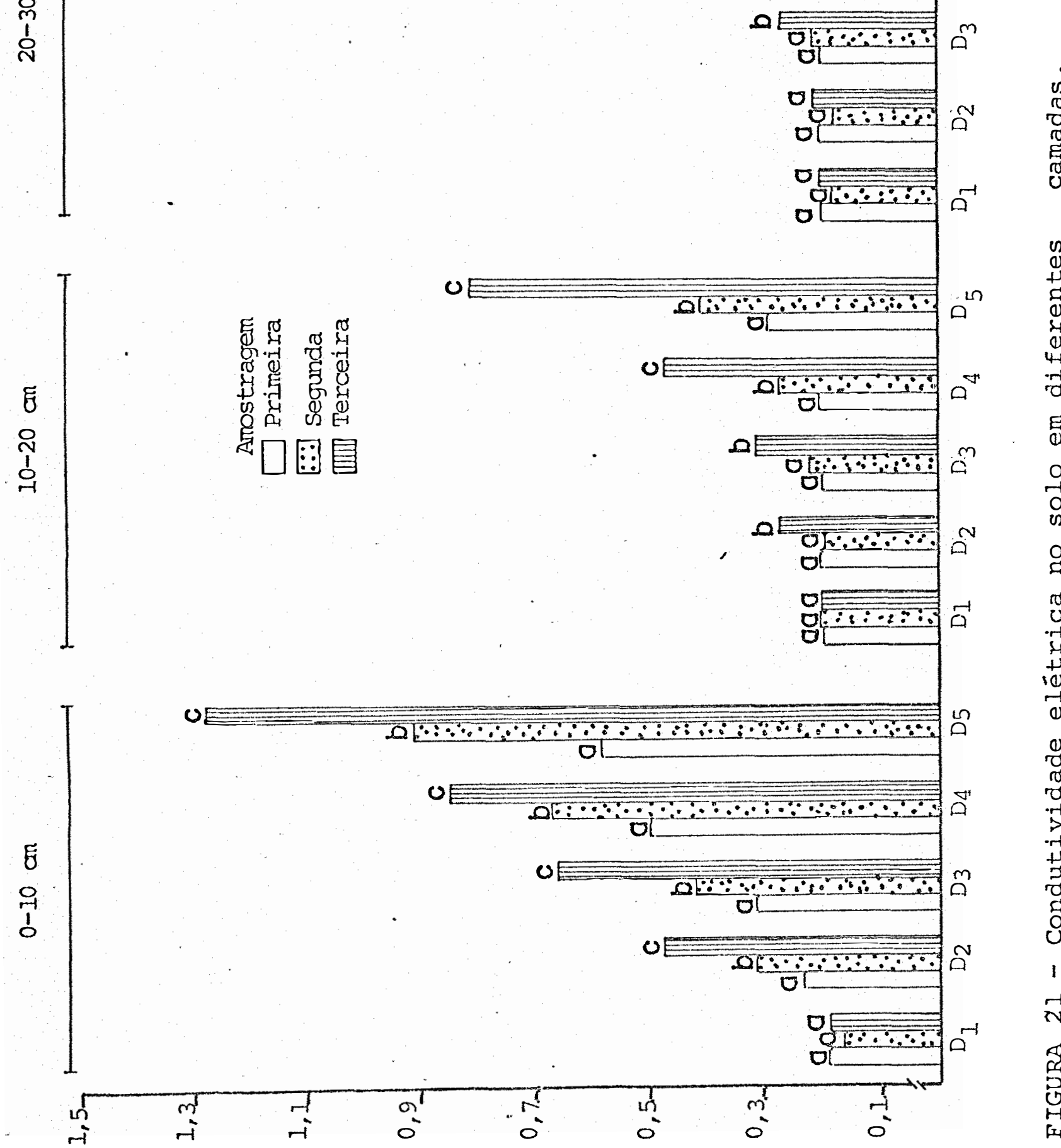

$\vec{a}$
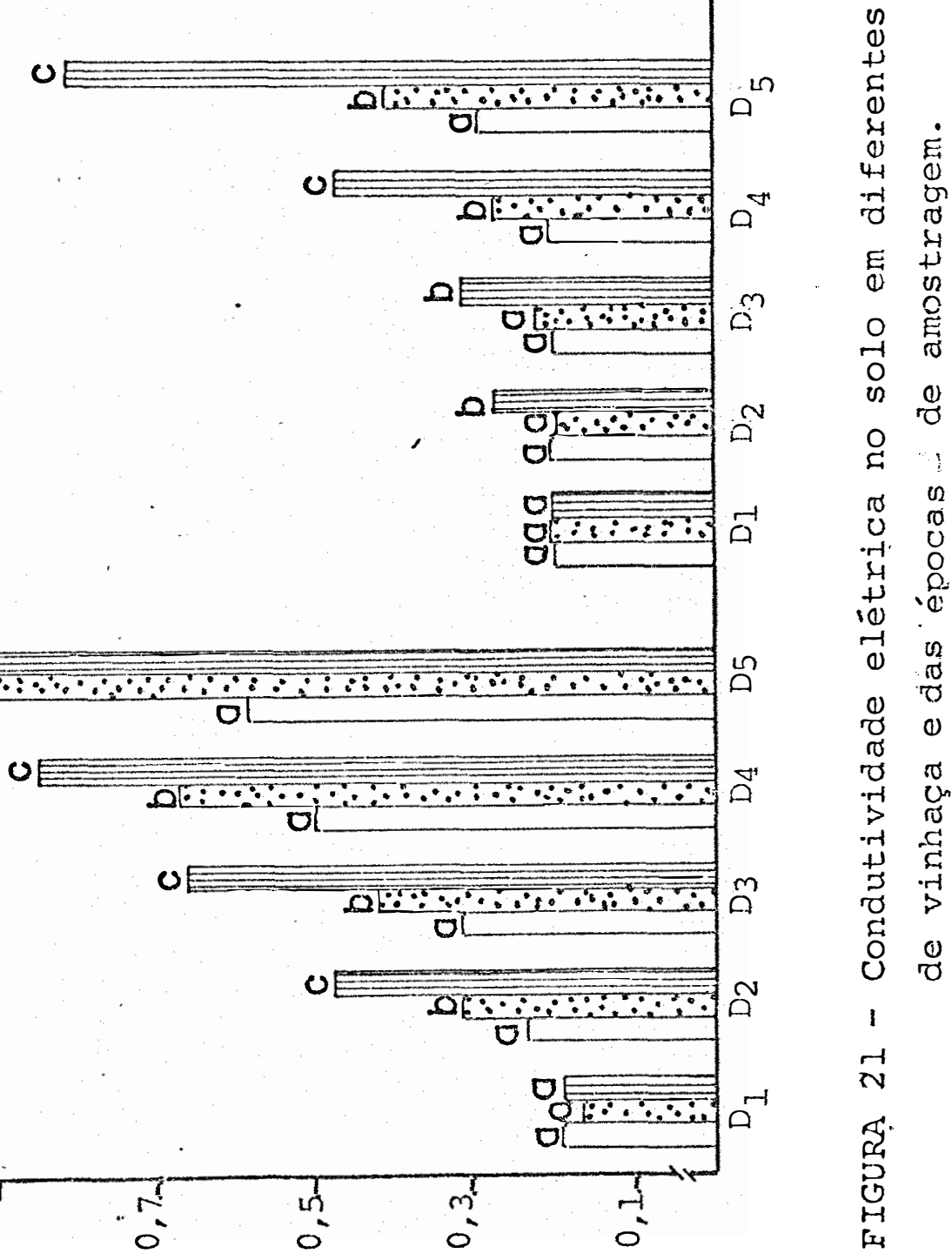
com $r=0,86 * *$ para $0-10 \mathrm{~cm}, y=0,8830 x+0,0029 \mathrm{com} r=0,97 * *$ para $10-20 \mathrm{~cm}$ e $y=0,1529 x+0,0019 \mathrm{com} x=0,91 * *$ para 20$30 \mathrm{~cm}$ de profundidade, onde $\mathrm{y}=$ valores da condutividade elé trica (mmhos $/ \mathrm{cm}$ a $25^{\circ} \mathrm{C}$ e $\mathrm{x}=$ concentrações de potássio no so lo $\left(\mu \mathrm{g} \cdot \mathrm{cm}^{-3}\right)$ vem indicar que a elevação da condutividade se deu em grande parte devido ao incremento do potássio no solo, corroborando os resultados obtidos por REZENDE (1979) e CAMAR GO et alii (1983)

Para correlacionar os resultados obtidos neste : estudo com efeitos na produção de cana-de-açūcar, adotou-se a relação $\operatorname{CE}(I: 1)=0,5$ C.E. (E.S.) proposta por MOLEN e HOORN (1980), onde $\operatorname{CE}(1: 1 j$ é a condutividade elétrica no extrato de solo-água $1: 1$ e C.E.(E.S.) é a determinada no extrato de solo saturado. Dessa maneira, multiplica-se por 2 os resultados de condutividade elētrica contidas nas tabelas $3,4,5$ e 8 .

Portanto, adotando o nîvel critico de FLOGLIATA e ASO (1965) igual a 1,2 mmhos/cm (E.S.), acima do qual pro voca drásticias reduções na velocidade de crescimento da canade-açücar e no seu teor de sacarose, óbserva-se na Tabela 3 que este valor já foi atingido nas parcelas que receberam o tratamento $\mathrm{D}_{3} \mathrm{C}_{1} \mathrm{E}_{2}$, para a camada de $0-10 \mathrm{~cm}$. por outro 
lado o nível crítico igual a 3,3 mmlos/cm (E.S.) citado por FAO (1979), acima do q̣ual ocorre drásticas reduções na produ ção, somente foi alcançado nas parcelas com os tratamentos $D_{5} C_{1} E_{3}$ que elevou a condutividade elétrica no extrato satura do para 3,34 mmnos/cm na profundidade de 0-10 cm.

Deve-se salientar, entretanto, que em nenhum tratamento utilizado não foi atingido o valor de 4,0 mmhos/ cm no extrato saturado, o qual se constitui em um dos crité rios adotados para classificação de solos salinos.

A condutividade elétrica apresentou um comporta mento diferente em relação as épocas da amestragem (Figura 21). Observa-se através desta que. a terceira amostragem apre senta os maiores valores daquelà variável nos primeiros $30 \mathrm{~cm}$ para todas as dose utilizadas, exceção feita para a dose $\mathrm{D}_{2}$ - de 20-30 cm de profundidade. Os maiores valores averiguados nesta época é uma consequência das aplicações sucessivas da vinhaça, apesar desta amostragem ser realizada no período chu voso Figura 14, concordando com os resultados obtidos por CA MARGO et alii (1983) e discordando com os de ORLANDO FILHO et alii (1983).

Neste sentido LEME et alii (1981), BAPTISTELLA 
et alii (1981) e ROSENFELD et alii (1983), verificaram que a vinhaça elevou os valores de condutividade elétrica logo após a sua aplicação, retornando os aos nĩveis originais após a estação chuvosa.

A importância da precipitação pluviométrica na diminuição da condutividade elétrica em solos que recebeu ví nhaça é mostrado nas Figuras 22 e 23. Assim atravēés da Figu ra 23 verifica-se que o seu valor é o dobro para a dose de $600 \mathrm{~m}^{3} /$ ha quando se compara os dados obtidos nos tratamentos com e sem cobertura para a camada de 0-10 cm. 
$\vdots$
0
0
1
0
0

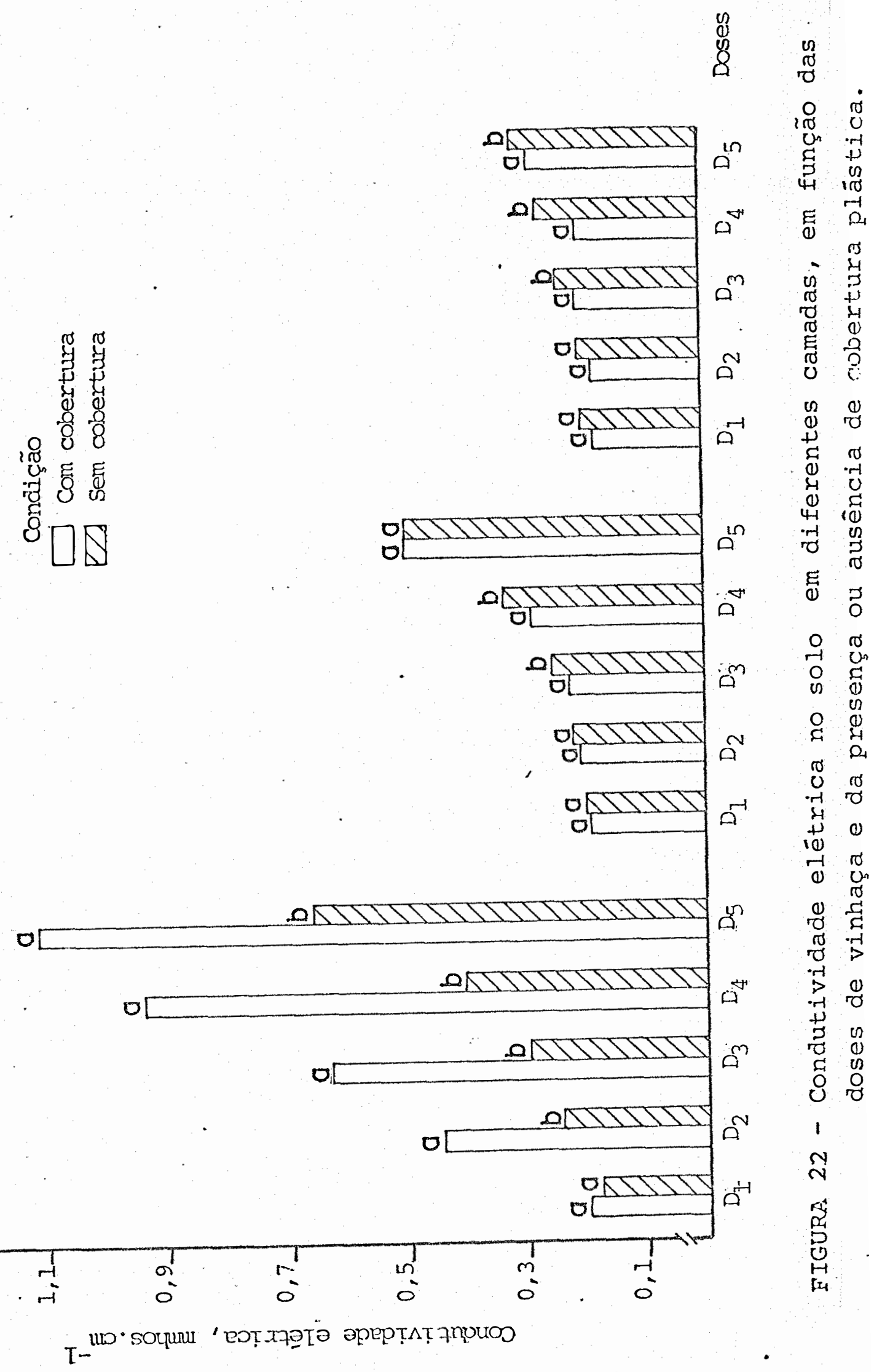




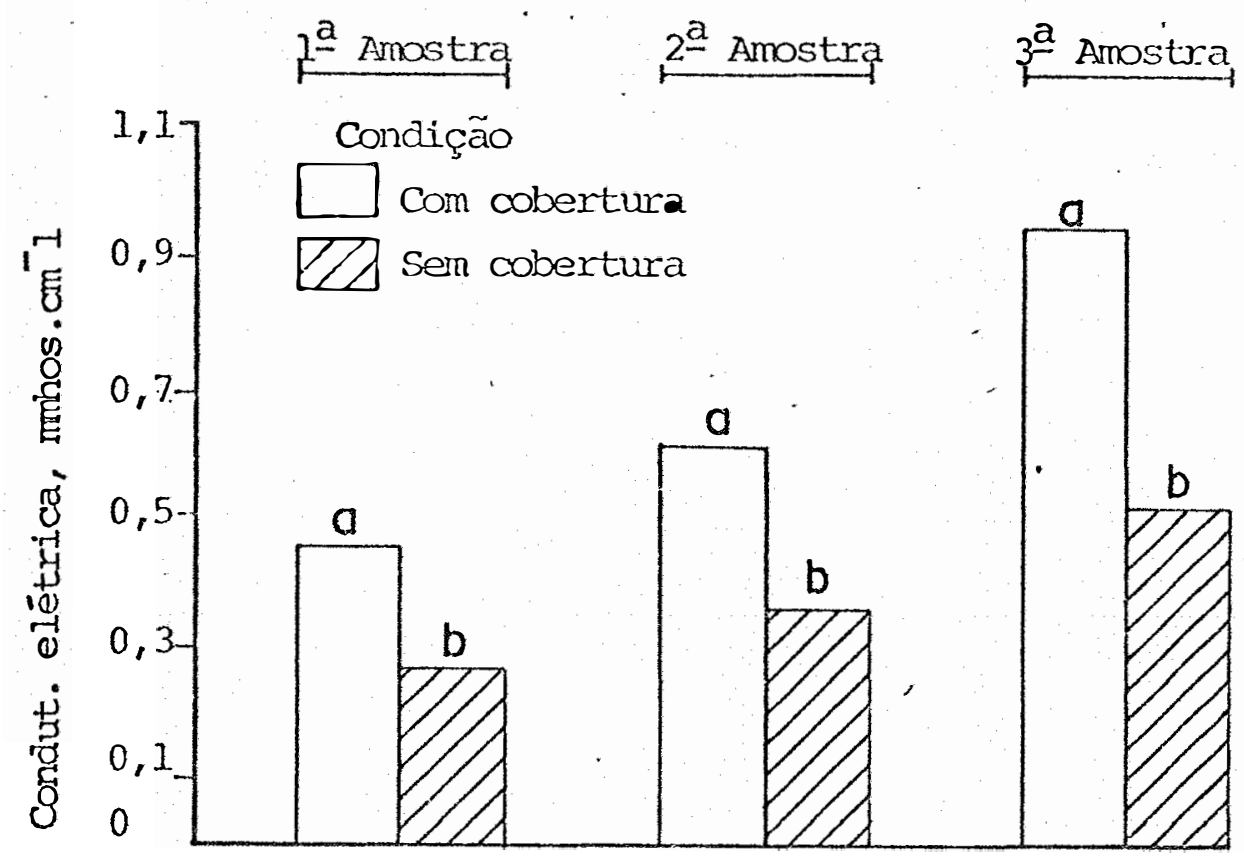

FIGURA. 23 - Condutividade elétrica no solo, na camada de $0-10 \mathrm{~cm}$, em função das épocas de amostragem e da presença ou ausência de cobertura plástica. 
5. CONCLUSÕES

Através dos resultados obtidos pode-se concluir que:

a) a densidade global, porosidade.total, macroporo sidade e microporosidade, grau de flociulação, os teores de ma têria orgânica e fôsforo não foram alterados significativamen te pelos tratamentos utilizados.

b) o teor de sais foi aumentado em função das do ses crescentes de vinhaça até $30 \mathrm{~cm}$ de profundidade.

c) os tratamentos com vinhaça que receberam as águas das chuvas apresentaram uma diminui.ção nos teores de sais, principalmente na camada de 0-10 cm.

d) as doses de vinhaça significativamente as con centrações de $\mathrm{Ca}, \mathrm{Mg}$ e $\mathrm{K}$ até as profundidades de 10, 30 e .60 . $\mathrm{cm}$ respectivamente e reduziram os teores de $\mathrm{H}+\mathrm{Al}$ nos pri meiros $10 \mathrm{~cm}$. 
pectivamente e reduziram os teores de H+Al nos primeiros 10 $\mathrm{cm}$.

e) as äguas das chuvas não afetaram significativa

- mente nos teores de $\mathrm{Mg}$ e $\mathrm{K}$ do solo a partir de 10 e $30 \mathrm{~cm}$ res pectivamente.

f) o comportamento dos valores da soma de bases, saturação de bases, $\mathrm{K} . \mathrm{S}^{-1} \cdot 100, \mathrm{~K} . \mathrm{T}^{-1} \cdot 100$ para os diferentes tratamentos é função principalmente das alterações ocorridas nos teores de $\mathrm{K}$. 
6. IITERATURA CITADA

AGUJARO, R., 1979. Uso da vinhaça na Usina Tamoio como fertí lizante. Saccharum-STAB, 2: 23-27.

ÀLMEIDA, J.R., 19ฐ2. O problema da vinhaça em São Paulo. Pí racicaba, Instituto Zimotécnico. 9p. (Boletim, 3).

ALMEIDA, J.R., 1953. Interferência dos fungos na adubação do solo pela vinhaça. Piracicaba, Instituto Zimotécnico. 10 p. (Boletim, 5).

ALMEIDA, J.R., 1962. Composição, proporção e aplicação da vinhaça.' In: SEMANA DE FERMENTAÇÃO ALCOOLICA, 3aㅡ, Piracica ba, Instituto Zimotécnico. p. 370-383.

ALMEIDA, J.R.; RANZANI, G.; VALSECHI, O., 1950. La vinasse dans l'agriculture. Piracicaba, Instituto Zimotécnico. 21 p. (Boletim, 1). 
AMARAL SOBRINHO, N.M.B.; VELLOSO, A.C.X.; LEAL, J.R.; ROSSIEL LO, R.O.P., 1983. Denitrifiçação e imobilização de nitrogê nio em solo tratado com vinhaça. R. bras. Ci. Solo, 7: 263 -268 .

ANDRIOLI, I., 1982. Movimento da vinhaça no solo Podzolizado Lins e Marília var. Marília. Jaboticabal, FCAV/UNESP, 89 p. (Dissertação de Mestrado).

BAPTISTELLA, J.R.; LEME, E.J.A.; ROSENFELD, U., 1981. Estụ do de doses de vinhaça aplicadas por aspersão em cana-deaçúcar. In: CONGRESSO NACIONAL DA STAB,' 20, Rio de Janei ro. Anais. v. 1, p. 215-234.

BAVER, L.D.; GARDNER, W.H.; GARDNER, W.R., 1972. SOil PhY sics. 4th ed., New York, John Wiley. 498 p.

BEAUCLAIR, E.G.F., 1984. Adubação verde e aplicação de matẹ ria orgânica no cultivo da cana-de-açúcar. In: COPERSUCAR. Reunião Técnica Agronômica: Manejo da adubação na cultura da cana-de-açúcar. p. 40-47.

BRIEGER, F., 1977. Observações sobre a distribuição de vinhą ça de caldo de destilariá do Estado de são Paulo. Brasil Açucareiro, 90: 23-30. 
CALDAS, H.E., 3960a. Calda de destilaria como fertilizante. Recife, Instituto Agronômico do. Nordeste. 107 p. (Boletim, 10).

CALDAS, H.E., 19்60b. Os fenômenos microbiológicos nos solos tratados com calda de destilaria. Recife, Instituto Agronô mico do Nordeste. 107 p. (Boletim, 10).

CAMARGO, D.A.; VALADARES, J.M.A.S.; GERALDI, R.N., 1983. Cạ racterísticas químicas e físicas de solo que recebeu vinha ça por longo tempo. Campinas, Instituto Agronômico. 30 p. (Boletim técnico, 76).

CAMARGO, R., 1954. O desenvolvimento da flora microbiana nos solos tratados com vinhaça. Piracicaba, Instituto zimotéc nico. 44 p. (Boletim, 9).

CAMBUIM, F.A. e CORDEIRO, D.A., 1986. Ação da vinhaça sobre pH, acidez total, acumulação e lixiviação de nutrientes em solo arenoso. STAB-Açúcar e Alcool, 4: 66-7l.

CATANI, R.A. e GALLO, J.R., 1955. Avaliação da exigência em calcário dos solos do Estado de São Paulo, mediante correla ção entre $\mathrm{o}$ pH e a porcentagem de saturação em bases. Rev. de Agricultura, 30: 49-60. 
CESAR, C.M. e MANFRINATO, H.A., 1954. O efeito anti-erosivo da vinhaça no solo. Rev. de Agricultura, 29: 75-81.

COLETI, J.T.; LORENZETTI, J.M.; GASPARINI, C.T.; DEMATTE, J. L.I., 1983. Efeito da aplicação de vinhaça nas proprieda des dos solos da Usina São José-Macatuba. STAB - Áçucar e Alcool e Subprodutos, 1: 12-17.

DAY, P.R., 1965. Particle fractronation and particle size analysis. In: BLACK, C.A., ed. Methods of soil analysis. Madison, Amer. Soc. Agron. p. 371-390.

EMBRAPA, 1979. Manual de métoḍos de análises de solos. Rio de Janeiro, Serviço Nacional de Levantamento e Conservação de Solos.

ESPINOZA, W. e REIS, A.E., 1982. Lixiviação de Ca, K e Mg em um Latossolo Vermelho Escuro (LE) de cerrados. Pesg. agropec. bras., 17: 299-317.

FAO, 1979. Yield response to water. Rome, 193 p. (FAO Irri gation and Drainaje Paper, 33).

FERREIRA, W.A., 1980. Efeito da vinhaça em solos de diferen tes texturas. Piracicaba, ESALQ/USP, 67 p. (Dissertação 
de Mestrado).

FOGLIATA, F.A. e ASO, P.I., 1965. Efectos de la salinidad $\mathrm{x}$ sodio intercambiable del suelo en el crescimento de la canã de azúcar. Rev. Ind. Agric. Tucuman, 43: 25-45.

GLORIA, N.A. e MAGRO, J.A., 1976. Utilização agrícola de re síduos da usina de açúcar na Usina da Pedra. In: SEMINARIO COPERSUCAR DA AGROINDÓSTRIA AÇUCAREIRA, 4\%, Aguas de Lin dóia. Anais. p. 163-180.

GLORIA, N.A. e ORLANDO FILHO, J., 1984. Aplicação de vinhą ça: um resumo e discussões sobre o que foi.pesquisado. l cool e Açũcar, 4: 22-31.

GLORIA, N.A.; SANTA ANA, A.G.; BIAGI, É, 1973. Composição dos resíduos de usina de açücar e destilarias. Brasil. Açu careiro, 81: 78-87.

GLORIA, N.A.; SANTA ANA, A.G.; MONTEIRO, H.; 1972. Composi - Ção dos resíduos de usinas de açúcar e destilarias de ál cool durante a safra canavieira. Brasil Açucareiro, 80: $542-548$.

LEAL, J.R.; AMARAL SOBRINHO, N.M.B.; VELLOSO, A.C.X.; ROSSIEL LO, R.O.P., 1983. Potencial redox e pH: variações em solo 
tratado com vinhaça. R. bras. Ci. Solo, 7: 257-261.

LEME, E.J.A.; ROSENFELD, U.; BAPTISTELLA, J.R. , 1980. UsO da vinhaça por aspersão com canhão hidrāulico. In: SIMPO SIO INTERNACIONAL SOBRE TECNOLOGIA DOS ALCOOIS COMO COMBUS TIVEL, 49, V.2, Guarujā. Anais. p. 815-821.

LIMA, I.T., 1980. Efeitos da aplicação de vinhaça sobre a mi croflora do solo. Rio de Janeiro, UFRRJ, 100 p. (Disser tação de Mestradol.

LOBATO, E.J.V., 1984. Variação da condutividade hidráulica de um solo tratado com vinhaça. Piracicabá, ESALQ/USP, 126 p. (Dissertação de Mestrado).

MAGRO, J.A., 1978. O uso da vinhaça em cana-de-açūcar na Usí na da Pedra - Serrana. Brasil Açucareiro, 92: 232-240.

MAZZA, J.A., 1985. Variações em algumas propriedades de so los com cana-de-açūcar tratados com doses maciças de vinha Ça. Piracicaba, ESALQ/USP, 204 p. (Dissertação de Mestrado).

MCLEAN, E.O., 1984. Interpretação de análise de solo. Campí. nas, Fundação Cargiłı. 40 p.

MOLEN, W.H. vander e HOORN, J.W. van, 1980. The salt balan 
ce and leaching requiriment of irrigated soils. In: XIX In ternational Course and Land Drainaje, Wageningen. Chap. $9,40 \mathrm{p}$.

NEVES, M.C.P., LIMA, I.T.; DOBEREINER, J., 1983. Efeito da vinhaça sobre a microflora do solo. R. bras. Ci. Solo, I: $131-136$.

NUNES, M.R.; LEAL, J.R.; VELLOSO, A.C., 1982. Efeito da vi nhaça na lixiviação de nutrientes do solo. III. Potássio, cálcio e magnésio. Pesq. agropec. bras., 17: 371-374.

NUNES, M.R.; VELLOSO, A.C.; LEAE, J.R., 1981. Efeito da vi nhaça nos cátions trocáveis e outros elementos químicos do solo. Pesq. agrop. bras., 16: 171-176:

ORLANDO FILHO, J. e ZAMBELLO JONIOR, E., 1980. Viagem de es tudos realizada à Africa do Sul, Filipinas, Havaí e Louisia na. Piracicaba, IAA/PLANALSUCAR. SUPER. 49 p.

ORLANDO FILHO, J.; ZAMBELLO JUNIOR, E.; AGUJARO, R.; ROSSE TO, A.J., 1983. Efeito da aplicação prolongada de vinhaça nas propriedades químicas dos solos com cana-de-açúcar. Es tudo exploratório. STAB, 1: 28-33.

RAIJ, B. van e QUAGGIC, J.A., 1983. Métodos de análise de so 
lo para fins de fertilidade. Instituto Agronômico, Campi nas. 31 p. (Boletim tēcnico, 81).

RAIJ, B. van e ZULLO, M.A.T., 1977. Métodos de anālise de solo. Campinas, Instituto Agronômico. 16 p. (Circular, 63).

RANZANI, G., 1956. Consequências da aplicação de restilo ao solo. Anais da ESALQ, 12: 57-68.

RASOVSKY, E.M., 1973. Alcool-Destilarias. Col. Canavie ra no 12, Divulgação do MIC-IAA.

REZENDE, J.O., 1979. Consequências da aplicação de vinhaça sô bre algumas propriedades físicas de um solo Aluvial: estudo de um caso. Piracicaba, ESALQ/USP (Tese de Doutoramento).

RIBEIRO, A.C.; NOVAIS, R.F.; BAHIA FILHO, A.F.C., 1983. Efei tos da vinhaça sobre a dispersão de argila de amostras de Latossolos. Rev. Ceres, 30: 12-18.

RIBEIRO, A.C. e SENGIK, E., 1983. Efeitos da aplicação de ví nhaça nas propriedades físicas e químicas de duas amostras de Latossolos. Rev. Ceres, 30: 25-31.

RODELLA, A.A. e FERRARI, S.E., 1977. A compoṣição da vinhaça 
e efeitos de sua aplicação como fertilizante na cana-de-açū car. Brasil Açucarciro, 90: 6-i3.

RODELLA, A.A.; ZAMBELLO JONIOR, E.; ORLANDO FILHO, J.; 1983. Effects of vinasse added to soil on $\mathrm{pH}$ and exchangeable alu minum content. In: CONGRESS OF INTERNATIONAL SOCIETY OF SU GAR CANE TECHNOLOGISTS, 189, La Habana. Proceedings. p. $189-214$.

ROSENFELD, U.; BAPTISTELLA, J.R.; LEME, E.J.A., 1981. Aplica Ção de vinhaça por aspersão em luatossolo Roxo. In: CONGRES SO NACIONAJ DA STAB, 29, Rio de Janeiro. Anais. v. l, p. 235-248.

ROSSIELLO, R.O.P.; FERREIRA, W.A.; FERNANDES, M.S., 1981. Re postas de milho à salinidade do solo induzida por aplicação de vinhaça. II. Produção de carboidratos solúveis e absor ção de nitrogênio. R. bras. Ci. Solo, $\underline{5}$ : 176-181.

RUSSELL, E.W., 1973. Soil conditions and plant growth. 10th. ed. London, Longman. 849 p.

SANTOS, G.A.; ROSSIELLO, R.O.; FERNANDES, M.S.; O'GRADY, P. C., 1981. Efeitos da vinhaça sobre o pH do solo, a germina Ção e o acúmulo de potássio em milho. Pesq. agropec. bras., 16: 489-493. 
SENGIK, E., 1983. Efeitos da vinhaça sobre o solo e conse quências sobre o crescimento do sorgo graniffero. Viçosa, UFV, 52 p. (Dissertação de Mestrado).

SOBRAL, A.F.; CORDEIRO, D.A.; SANTOS, M.A.C., 1981. Efeitos da aplicação de vinhaça em socarias de cana-de-açūcar. Bra sil Açucareiro, 98: 368-374.

UHLAND, R.E., 1949. Physical properties of soils as modified by crops and management. Soil Sci. Soc. Am. Proc., 14: 361 -366 .

U.S.D.A., 1951. Soil survey manual. Washington, Soil Survey Staff, Soil Conservation Service. 503 p. (Handbook, 18).

VALSECHI, O. e GOMES, F.P., 1954. Solos incorporados com vi nhaça e seu teor em bases. Anais da ESALQ, 11: 136-158.

VELLOSO, A.C.X; NUNES, M.R.; LEAL, J.R., 1982. Efeito da vi nhaça na lixiviação de nutrientes do solo. I. Nitrato e amônio. pesg. aguopec. bras., 17: 51-55.

VOMOCIL, J.A., 1965. Porosity. In: BLAKE, A.C. Methods of soil analysis. Madison, Amer. Soc. Agron., part 1, p. $299-314$. 